\title{
Geographical and altitudinal distribution of Brachycephalus (Anura: Brachycephalidae) endemic to the Brazilian Atlantic Rainforest
}

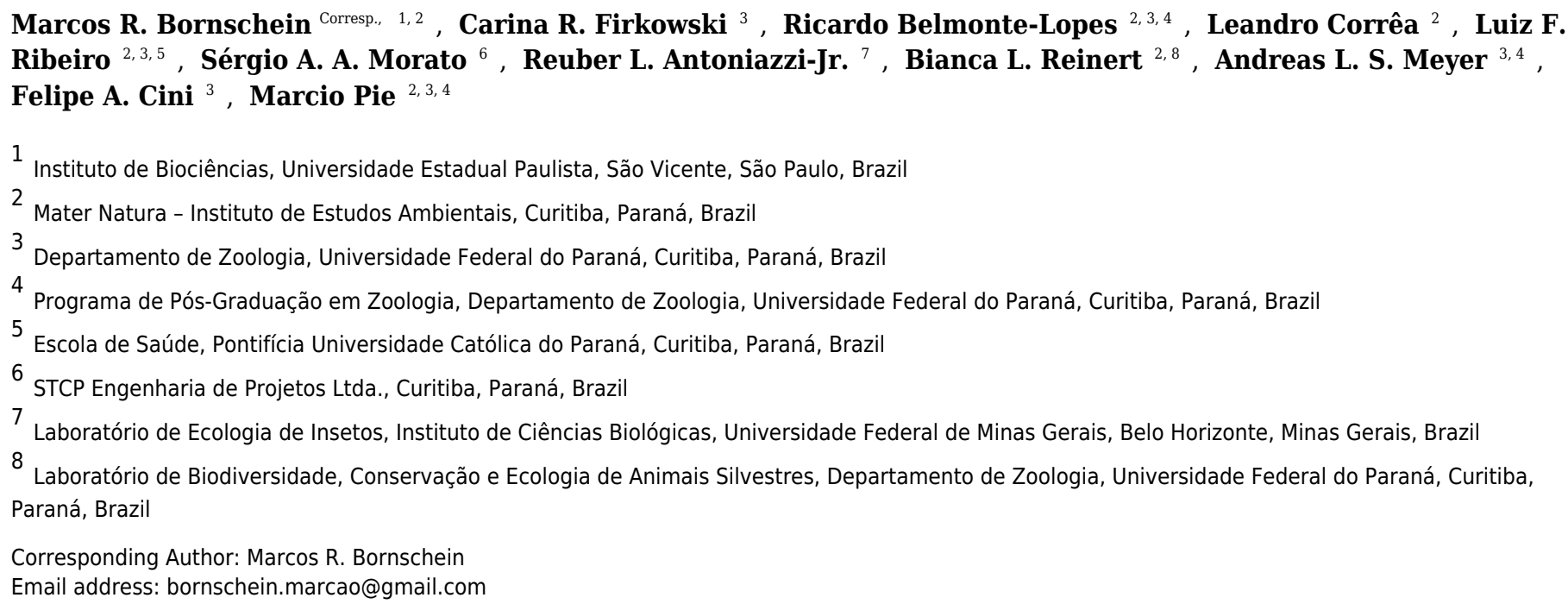

Mountains of the Brazilian Atlantic Forest can act as islands of cold and wet climate, leading to the isolation and speciation of species with low dispersal capacity, such as the toadlet species of the genus Brachycephalus. This genus is composed primarily by diurnal species, with miniaturized body sizes $(<2.5 \mathrm{~cm})$, inhabiting microhabitats in the leaf litter of montane forests. Still little is known about the geographical distribution, altitudinal range, and ecological limits of most Brachycephalus species. In this study we review the available data on the geographical and altitudinal distribution of Brachycephalus based on occurrence records compiled from literature and museums, both for the genus as a whole and separately for the three recently proposed groups of species (ephippium, didactylus, and pernix). The final ensemble dataset comprised 333 records, 120 localities, 28 described species, and six undescribed ones. Species were recorded in six relief units, the richest of which being the Serra do Mar, with 30 species. When the Serra do Mar is subdivided into three subunits, Northern, Central and Southern Serra do Mar, the number of species increase from north to the south, with records of six, nine, and 16 species, respectively. We were able to estimate the extent of occurrence of nearly half of the described species, and the resulting estimates indicate that many of them show remarkably small ranges, some of which less than 50 ha. Brachycephalus species are present from sea level to roughly $1,900 \mathrm{~m}$ a.s.l., with the highest richness being found between 751 and 1,000 $\mathrm{m}$ a.s.l. (21 spp.). The species with the broadest altitudinal range 
were $B$. didactylus $(1,075 \mathrm{~m})$ and Brachycephalus sp. 1 (1,035 m), both in the didactylus group, and $B$. ephippium (1,050 $\mathrm{m}$ ), of the ephippium group. The broadest altitudinal amplitude for species of the pernix group was recorded for B. brunneus (535 m). The lowest altitudinal records for the pernix group were at $845 \mathrm{~m}$ a.s.l. in the state of Paraná and at $455 \mathrm{~m}$ a.s.l. in the state of Santa Catarina. The altitudinal occurrence in the pernix species group seems to decrease southward. Syntopy between species is also reviewed. 
1 Geographical and altitudinal distribution of Brachycephalus (Anura: Brachycephalidae)

2 endemic to the Brazilian Atlantic Rainforest

3

4 Marcos R. Bornschein ${ }^{1,2,9}$, Carina R. Firkowski ${ }^{3}$, Ricardo Belmonte-Lopes ${ }^{2,3,4}$, Leandro

5 Corrêa $^{2}$, Luiz F. Ribeiro ${ }^{2,3,5}$, Sérgio A. A. Morato ${ }^{6}$, Reuber Lana Antoniazzi-Jr ${ }^{7}$, Bianca L.

6 Reinert $^{2,8}$, Andreas L. S. Meyer ${ }^{3,4}$, Felipe A. Cini ${ }^{3}$ \& Marcio R. Pie ${ }^{2,3,4}$

7

$8{ }^{1}$ Instituto de Biociências, Universidade Estadual Paulista, Campus do Litoral Paulista, Praça

9 Infante Dom Henrique s/no, Parque Bitaru, CEP 11330-900, São Vicente, São Paulo, Brazil

$102^{2}$ Mater Natura - Instituto de Estudos Ambientais, Rua Lamenha Lins 1080, CEP 80250-020,

11 Curitiba, Paraná, Brazil

$12{ }^{3}$ Departamento de Zoologia, Universidade Federal do Paraná, CEP 81531-990, Curitiba, Paraná,

13 Brazil

$14{ }^{4}$ Programa de Pós-Graduação em Zoologia, Departamento de Zoologia, Universidade Federal do 15 Paraná, CEP 81531-990, Curitiba, Paraná, Brazil

$16{ }^{5}$ Escola de Saúde, Pontifícia Universidade Católica do Paraná, Rua Imaculada Conceição 1155 ,

17 Prado Velho, CEP 80215-901, Curitiba, Paraná, Brazil

$18{ }^{6}$ STCP Engenharia de Projetos Ltda., Rua Euzébio da Motta, 450, CEP 80.530-260, Curitiba,

19 Paraná, Brazil

$20{ }^{7}$ Laboratório de Ecologia de Insetos, Instituto de Ciências Biológicas, Universidade Federal de

21 Minas Gerais, Av. Antônio Carlos 6627, Pampulha, CEP 31270-901, Belo Horizonte, Minas

22 Gerais, Brazil

$23{ }^{8}$ Laboratório de Biodiversidade, Conservação e Ecologia de Animais Silvestres, Departamento

24 de Zoologia, Universidade Federal do Paraná, CEP 81531-990, Curitiba, Paraná, Brazil

$259{ }^{9}$ Corresponding author: Marcos R. Bornschein. E-mail: bornschein.marcao@gmail.com 26

27

28 Short title: Distribution of Brachycephalus spp. 


\section{Abstract}

32 Mountains of the Brazilian Atlantic Forest can act as islands of cold and wet climate, leading to 33 the isolation and speciation of species with low dispersal capacity, such as the toadlet species of 34 the genus Brachycephalus. This genus is composed primarily by diurnal species, with 35 miniaturized body sizes $(<2.5 \mathrm{~cm})$, inhabiting microhabitats in the leaf litter of montane forests. 36 Still little is known about the geographical distribution, altitudinal range, and ecological limits of 37 most Brachycephalus species. In this study we review the available data on the geographical and 38 altitudinal distribution of Brachycephalus based on occurrence records compiled from literature 39 and museums, both for the genus as a whole and separately for the three recently proposed

40

41

42 55

56

57

58

59 60 groups of species (ephippium, didactylus, and pernix). The final ensemble dataset comprised 333 records, 120 localities, 28 described species, and six undescribed ones. Species were recorded in six relief units, the richest of which being the Serra do Mar, with 30 species. When the Serra do Mar is subdivided into three subunits, Northern, Central and Southern Serra do Mar, the number of species increase from north to the south, with records of six, nine, and 16 species, respectively. We were able to estimate the extent of occurrence of nearly half of the described species, and the resulting estimates indicate that many of them show remarkably small ranges, some of which less than 50 ha. Brachycephalus species are present from sea level to roughly 1,900 $\mathrm{m}$ a.s.1., with the highest richness being found between 751 and 1,000 $\mathrm{m}$ a.s.1. (21 spp.). The species with the broadest altitudinal range were B. didactylus $(1,075 \mathrm{~m})$ and Brachycephalus sp. $1(1,035 \mathrm{~m})$, both in the didactylus group, and B. ephippium $(1,050 \mathrm{~m})$, of the ephippium group. The broadest altitudinal amplitude for species of the pernix group was recorded for $B$. brunneus $(535 \mathrm{~m})$. The lowest altitudinal records for the pernix group were at $845 \mathrm{~m}$ a.s.1. in the state of Paraná and at $455 \mathrm{~m}$ a.s.l. in the state of Santa Catarina. The altitudinal occurrence in the pernix species group seems to decrease southward. Syntopy between species is also reviewed.

\section{Introduction}

Brachycephalus Fitzinger is a genus of miniaturized diurnal toadlets (usually $<2.5 \mathrm{~cm}$ in snoutvent length) that inhabit the forest floor of montane regions along the Atlantic Rainforest of southeastern and southern Brazil (Izecksohn 1971; Giaretta \& Sawaya 1998; Pombal et al. 1998; 
62 Napoli et al. 2011; Pie et al. 2013; see Rocha et al. [2000] and Pombal \& Izecksohn [2011] for 63 reports of nocturnal activity). Brachycephalus presents direct development and a reduction in the 64 number and size of digits (Hanken \& Wake 1993; Pombal 1999; Yeh 2002). Some species are 65 aposematic (yellow, orange or yellow with light red), of which some were confirmed as 66 harboring neurotoxins (tetrodotoxin and analogues; Sebben et al. [1986]; Pires et al. [2002, 67 2003]; Schwartz et al. [2007]).

68 Recently, Kaplan (2002) proposed that the genus Psyllophryne Izecksohn should be 69 considered as a junior synonym of Brachycephalus. Psyllophryne included two species, $P$. 70 didactyla and $P$. hermogenesi, "with dorsal surfaces brown, tiny body sizes [snout-vent length 71 8.6-10.2 mm], body leptodactyliform, and long-distance jumpers" (Napoli et al. 2011). There are 72 currently 29 described species of Brachycephalus (Frost 2015; see Pie \& Ribeiro 2015; Ribeiro 73 et al. 2015), and although 20 of them were described within the last 10 years, it is likely that 74 75 many more species are still waiting to be described. Moreover, ecological data on species of the genus Brachycephalus is still limited. To date it only includes data on the breeding behavior of B. ephippium (Pombal et al. 1994; Pombal 1999); vocal activity of B. hermogenesi (Verdade et al. 2008); advertisement calls of B. ephippium (Pombal et al. 1994), B. hermogenesi (Verdade et al. 2008), B. pitanga (Araújo et al. 2012), B. tridactylus (Garey et al. 2012), and B. crispus (Condez et al. 2014); abundance estimates of B. didactylus (Van Sluys et al. 2007; AlmeidaSantos et al. 2011; Rocha et al. 2013; Siqueira et al. 2014) and its diet (Almeida-Santos et al. 2011); the diet of B. brunneus (Fontoura et al. 2011), B. garbeanus (Dorigo et al. 2012), and B. pitanga (Oliveira \& Haddad 2015); and microhabitat preference of B. garbeanus (Dorigo et al. 83 2012).

A recently-proposed phylogenetic hypothesis for the genus indicated their separation into three main clades, with still some uncertainty regarding relationships within each clade (Clemente-Carvalho et al. 2011a). Based on the species studied by Clemente-Carvalho et al. (2011a), one clade included B. didactylus and B. hermogenesi; a second clade, included B. brunneus, B. ferruginus, B. izecksohni, B. pernix, and B. pombali; and a third clade included $B$. alipioi, B. ephippium, B. garbeanus, B. nodoterga, B. pitanga, B. toby, and B. vertebralis. Two morphological traits - the presence/absence of dermal co-ossification and body shape - were used to distinguish three groups of species (Ribeiro et al. 2015), namely ephippium, didactylus, and pernix groups. The first was defined by the presence of dermal co-ossification and bufoniform 
93 body shape and includes the following species, distributed in southeastern Brazil (from the state 94 of Espírito Santo south to the state of São Paulo): B. alipioi, B. bufonoides, B. crispus, B. ephippium, B. garbeanus, B. guarani, B. margaritatus, B. nodoterga, B. pitanga, B. toby, and B. vertebralis (Ribeiro et al. 2015). The didactylus group was defined by the absence of dermal coossification and a leptodactyliform body shape and includes B. didactylus, $B$. hermogenesi, and B. pulex (Ribeiro et al. 2015). Finally, the pernix group was defined by the absence of dermal coossification and bufoniform body shape, and includes the following species, distributed in southern Brazil (states of Paraná and Santa Catarina): B. auroguttatus, B. boticario, B. brunneus, B. ferruginus, B. fuscolineatus, B. izecksohni, B. leopardus, B. mariaeterezae, B. olivaceus, B. pernix, B. pombali, B. tridactylus, and B. verrucosus (Ribeiro et al. 2015). Later, an additional species from the pernix group was described from southern Brazil (Pie \& Ribeiro 2015): B. quiririensis. On the other hand, the holotype of Brachycephalus atelopoide is currently missing (Pombal 2010) and no population of this species in nature is known. Therefore, given that diagnostic characters could not be inspected, B. atelopoide was not assigned to any of the species groups (Ribeiro et al. 2015). A recent study by Padial et al. (2014) indicated that B. hermogenesi would be closely related to a species of the ephippium group, implying that the didactylus and ephippium clades were not monophyletic, but the authors used the same dataset as the original Clemente-Carvalho et al. (2011a) study. One possibility for this incongruence is that Padial et al. (2014) only analyzed the concatenated dataset, which could have masked variations among different among loci that were accounted for in species tree analyses by Clemente-Carvalho et al. (Ribeiro et al. 2015).

An intriguing aspect of Brachycephalus is the high level of microendemism found in most of its species. For instance, extensive field surveys often find species confined to one or a few adjacent mountaintops along the Atlantic Forest (Pie et al. 2013), suggesting that their diversification is strongly linked to the topographical characteristics of their habitats. Therefore, to understand the origin and distribution of Brachycephalus, it is crucial to integrate species occurrence data with the geographical attributes of the biomes where they are found. The Atlantic Forest, the second largest forested biome of South America, can be divided at least into eight broad relief units, of which three correspond to higher altitude regions, namely plateaus ("Planaltos"), mountain ranges ("Serras"), and escarpments ("Escarpas") (IBGE 1993). The highest mountains of the Atlantic Forest biome occur in the Serra da Mantiqueira and Serra do 
124 Mar. Their formation is associated with tectonic events dating back to the Paleocene, which 125 caused an uplift of an eastern sector of southeastern Brazil and led to a depression in the eastern 126 border. This region was subsequently submerged by the ocean and led to the formation of the 127 Santos basin (Almeida \& Carneiro 1998). A second downgrade occurred further inland, 128 establishing the Serra da Mantiqueira (it extends throughout the states of Espírito Santo, Minas 129 Gerais, Rio de Janeiro, and São Paulo; Almeida \& Carneiro [1998]), which is currently divided 130 by the "Paraíba do Sul" river valley into northern and southern rims (IBGE 1993, 2006; IBAMA 131 2007). The Serra do Mar, formed between 300 and 400 million years before present, contitutes 132 the new eastern border of the Brazilian plateau that was progressively eroded westward, leaving 133 remnants that formed coastal islands (Almeida \& Carneiro 1998). This edge of the plateau, called 134 Serra do Mar, was interrupted from the southern state of São Paulo by headward erosion of the 135 Ribeira river valley and from its lower limit in northeastern state of Santa Catarina by headward 136 erosion of the Itajaí Açu river valley (Almeida \& Carneiro 1998).

137 Millions of years of erosion processes have shaped the escarpments and mountains in 138 eastern and southern Brazil. Instead of forming a continuous massif range, several blocks of high 139 elevation isolated by lower areas have been formed, constituting a mountain range. These blocks 140 receive one or more regional names of "Serras", the highest of which being Serra do Caparaó 141 (2,892 m a.s.l.) and Serra do Itatiaia (2,791 m a.s.1.), both part of Serra da Mantiqueira. The Serra 142 do Mar in its northern limit (northern state of Rio de Janeiro) is characterized by several 143 "Serras", with the highest peak reaching up to 2,230 $\mathrm{m}$ a.s.l. Its middle section presents a 144 distinctive structure, featuring a high plateau at the border between the states of Rio de Janeiro 145 and São Paulo, which decreases in altitude southward until southeast of São Paulo city. In this 146 region around the São Paulo city, the Serra do Mar is characterized as a border of the plateau 147 (Almeida \& Carneiro 1998), reaching 800-900 $\mathrm{m}$ a.s.l., whereas in the border between the states 148 of São Paulo and Rio de Janeiro its altitude reaches up to 2,050 m a.s.l. In the state of Paraná, the 149 Serra do Mar is characterized again by several "Serras" with altitudes from 500 to 1,000 m above 150 the plateau (Maack 1981); the highest peak reaches up to 1,800 m a.s.l. (sensu Google Earth 151 [satellite image from 2015], or 1,922 m a.s.l., sensu Maack [1981]). The Serra do Mar in the state 152 of Santa Catarina has a very short extension (about $45 \mathrm{~km}$ in a north/south straight line). The 153 highest altitudes are found only near the border with the state of Paraná, where it reaches up to 
$1541,524 \mathrm{~m}$. Further south, the Serra do Mar becomes increasingly lower, reaching only $\sim 600 \mathrm{~m}$ 155 a.s.l. on the southern edge of occurrence of this relief unit.

156 The mountainous regions of the Atlantic Forest might have contributed to the formation and 157 distribution limits of Brachycephalus in several ways. For instance, mountains could have 158 supported population remnants of many species during warmer periods throughout the 159 Quaternary (e.g. Carnaval et al. [2009]; Brunes et al. [2010]; Thomé et al. [2010]; Amaro et al. 160 [2012]; see also Wollenberg et al. [2011]; Páez-Moscoso \& Guayasamin [2012], and Giarla et al. 161 [2014] for similar scenarios in other montane regions), mainly due to their distinctly colder and 162 wetter climatic conditions. Hence, they played an important role in the diversification of animals 163 with low dispersion capacities, including certain birds (Mata et al. 2009) and amphibians (Cruz 164 \& Feio 2007; Brunes et al. 2010; Thomé et al. 2010). This has been confirmed in an investigation 165 of the environmental niches of different Brachycephalus species groups, given that they were 166 167 168 169 170 171 shown to occupy distinct regions of climatic space (Pie et al. 2013). That analysis included most of the described species (as well some that were undescribed) and was based occurrence records associated with species descriptions, museum specimens, and a few comprehensive references. They have also presented new geographical distribution limits for the genus and records of altitude for all species. However, no study to date has explored explicitly the altitudinal variation and provided estimates of geographical distributions of Brachycephalus species.

Understanding the ecological limits, geographical distributions, and altitudinal ranges of Brachycephalus species is of considerable importance, particularly to direct more effective conservation actions. In the present study, we address the aforementioned aspects by reviewing the geographical and altitudinal distribution of Brachycephalus based on records compiled from literature and museum specimens. In particular, expanding a previous effort by Pie et al. (2013), we now include the entire literature on Brachycephalus, which nearly tripled the number of sources in relation to that study. We analyze the geographical distribution and altitudinal amplitude of occurrence of the genus as a whole, as well as separately based on their species groups.

\section{Materials and methods}

Species records 
185 In an earlier paper (Pie et al. 2013), occurrence records of Brachycephalus species were obtained 186 from the SpeciesLink portal (www.splink.org.br), as well as from DZUP (Coleção de 187 Herpetologia, Departamento de Zoologia, Universidade Federal do Paraná, state of Paraná, 188 Brazil) and MHNCI (Museu de História Natural Capão da Imbuia - Prefeitura Municipal de 189 Curitiba) collections, and from the species descriptions themselves. For this paper we expanded 190 that dataset by compiling additional records from DZUP and from a broader review of the 191 literature. A few unpublished records obtained by the authors in southern Brazil were also 192 included to improve the dataset. Collection, handling and preservation permits were issued by 193 ICMBIO (22470-1 and 22470-2). We carried out the same careful analysis as in Pie et al. (2013) 194 to check the precise geographical coordinates of point records using topographic maps (at 195 different scales), resources of the Google Earth software, including the titles of photographs 196 associated with different locations, and descriptive information of localities in other publications. 197 The final dataset used for the analyses included only those records which coordinate precision 198 index value was between 1.1 and 3.0, according to McLaren et al., reprinted in Knyazhnitskiy et 199 al. (2000). To help further revisions, we also listed occurrence records considered imprecise after our revision (see Results). Although there are methods for georeferencing imprecise locations

201 202 203 204 205 206 207 208 209 210 211 212 213 214 215 (e.g. Wieczorek et al. 2004), we preferred to discard the records that did not meet these standards.

Altitudinal records were either compiled from the literature or, when that information was unavailable, by plotting occurrence records on Google Earth. The altitudinal range of some species were obtained directly from the literature or from the field by the authors. The altitudinal range represents the lower and higher altitudinal occurrence record of a species in a given locality. Although some records had precise locations, they were located on slopes where the exact altitude of the record was difficult to ascertain and therefore were omitted from further analysis, but not from the compiled table, to assist future revisions.

All records were associated with Brazilian relief units (IBAMA 2007) by simply plotting each record against a map of the limits of different relief units. In two of the major relief units, we also analyzed our data separately for their subunits as follows: the Serra da Mantiqueira as "Northern Serra da Mantiqueira" (states of Espírito Santo and adjacent Minas Gerais) and "Southern Serra da Mantiqueira" (states of Minas Gerais, Rio de Janeiro, and São Paulo), and the Serra do Mar as "Northern Serra do Mar" (state of Rio de Janeiro), "Central Serra do Mar" 
216 (southern state of Rio de Janeiro and state of São Paulo), and "Southern Serra do Mar" (southern 217 state of São Paulo and states of Paraná and Santa Catarina). The Serra da Mantiqueira we 218 subdivided into two sectors because this unit comprises naturally two sectors, isolated by the 219 "Paraíba do Sul” relief unit (IGBE 1993, 2006; IBAMA 2007). The Serra do Mar we subdivided 220 into sectors according to the interruption of escarpments (IGBE 2006). Geographical coordinates 221 are based into the WGS84 datum.

222

223 Geographical distribution measurement

224 We tentatively provide estimates of species geographical distributions as their "extent of 225 occurrence", sensu IUCN (2012), using two methods. The first is an adaptation of "minimum 226 convex polygon" (Mohr 1947), as Reinert et al (2007), which allowed for changing the shape of 227 the minimum convex polygon, whenever it was possible, to remove areas that are obviously 228 unsuitable for the persistence of the species, such as cities, plantations, bodies of water, and 229 vegetation in the early stages of regeneration, as well areas beyond the altitudinal amplitude 230 record of the species. In the second method, we made polygons by considering the lowest 231 altimetric quota with records of the species, while also omitting unsuitable areas (as above). We 232 made these environmental and altitudinal assessments and produced the resulting polygons using 233 Google Earth Pro 7.1.4.1529. We then measured the areas encompassed by each polygon using 234 GEPath 1.4.5. Although we disregarded unsuitable areas when drawing the polygons, we treated 235 the resulting measurements as "extent of occurrence" and not "area of occupancy" (sensu IUCN 236 2012) because micro habitat requirements can prevent the species from occurring in some parts 237 of the area within the polygons. Unfortunately, we were unable to determine occurrence 238 polygons of many species when the abovementioned criteria led to obviously unrealistic 239 distribution polygons, primarily for the following reasons: 1) when there were exceedingly few 240 records that were usually very scattered and/or encompassed vast degraded areas, or 2) when the 241 altitudinal range of occurrence of a species based on their altitudinal limits encompassed 242 unreasonably large areas (usually heading west).

243

244 Species groups

245 All described species in the present compilation were assigned to one of the three species groups 246 by Ribeiro et al. (2015), except for B. atelopoide (see above). The present compilation also 
247 includes some undescribed species not yet assigned to one of the three groups; all of them were 248 mentioned as new species or potentially new species in the respective source of their records.

249 Two of them were here assigned to the ephippium group because they probably represent 250 populations of $B$. ephippium that could be split into two species, one of which from the state of 251 Rio de Janeiro (Siqueira et al. 2013; see also Siqueira et al 2011) and the other from the state of 252 São Paulo (Pie et al. 2013). A third undescribed species was assigned to the didactylus group 253 because it represents a population to be split from $B$. hermogenesi (Pie et al. 2013), a 254 representative species from the didactylus group. Finally, the other three populations were 255 assigned to the pernix group because they were previously assigned to the "pernix clade" (Pie et 256 al. 2013), whose members all belong to the pernix group (Ribeiro et al. 2015).

257

258

259

260

261

262

263

264

265

266

267

268

269

270

271

272

273

274

275

276

277

\section{Results}

The final dataset is composed of 333 records (from 73 distinc sources) of 120 localities (three of which representing novel unpublished records). These records involve the geographic occurrence of 28 formally known and six undescribed species, including 82 previous records that had been excluded based on the accuracy criteria indicated above (Tab. 1). Species were recorded in six relief units, the richest of them being Serra do Mar, with 30 species (six undescribed; Fig. 1), followed by Serra da Mantiqueira and Leste Catarinense, with three species each (Tab. 2). Northern Serra da Mantiqueira has records of all three species of this relief unit, while Southern Serra da Mantiqueira has records of only one species. In Serra do Mar, species richness increases from north to south, with records of six species (one undescribed) in Northern Serra do Mar, nine (one undescribed) in Central Serra do Mar, and 16 (four undescribed) in Southern Serra do Mar (Tab. 2; Fig. 1). Finally, Pré-Litorâneas, Paraíba do Sul, and Paranapiacaba relief units have records of only one species each (Paranapiacaba has records of an undescribed species; Tab. 2).

The northernmost and southernmost records are 1,592 km distant from each other in a straight line; the species recorded in these limits are B. pulex and B. fuscolineatus, respectively (Tab. 1).

The didactylus group comprises four species (one undescribed) encompassing the broadest geographical distribution of all three groups, from the northernmost record for the genus (state of Bahia, with B. pulex) southward to the north of Santa Catarina state, with Brachycephalus sp. 1 (Tab. 1; Fig. 2B). Three species occur in Serra do Mar (one undescribed), but only one species 
278 occurs in each of Northern, Central and Southern Serra do Mar (Southern Serra do Mar has 279 records of one undescribed species; Tab. 3). Only one species occurs in the three remaining relief 280 units with presence of this group (Pré-Litorâneas, Serra da Mantiqueira, and Paranapiacaba, with 281 the latter being represented by an undescribed species; Tab. 3). There are no records of this 282 group inland in the "Southern Serra da Mantiqueira" but there are records relatively further 283 inland in "Paranapiacaba", in the state of Paraná (Fig. 2B).

284 The ephippium group comprises 13 species (two undescribed; Tab. 1). It has a more 285 intermediate geographical distribution in relation to the overall latitudinal distribution of the 286 genus, from the state of Espírito Santo to southern state of São Paulo (Fig. 2C); the species 287 recorded in those extreme geographical limits are B. alipioi and B. ephippium, respectively. The 288 group is represented in all relief units encompassed in this region (Serra da Mantiqueira, Paraíba 289 290 291 292 293 294 295 296 297 298 299 300 do Sul, and Serra do Mar; Tab. 1; Fig. 2C). It is highly represented by species in Serra do Mar (12 species, two of which undescribed; Fig. 1), whereas in Serra da Mantiqueira there is records of two species and in Paraíba do Sul of only one (Tab. 3). Northern Serra da Mantiqueira has two species, while Southern Serra da Mantiqueira has only one (Tab. 3). Northern Serra do Mar has five species (one undescribed) and Central Serra do Mar has eight species (also with one undescribed); Southern Serra do Mar does not harbor any species of this group (Tab. 3; Fig. 1).

The pernix group is the most species-rich group, with 17 species (three undescribed; Tab. 1). It has the smallest geographical distribution, restricted to the states of Paraná and Santa Catarina, southern Brazil (Fig. 1D), comprising the southernmost distribution of the genus, with $B$.

fuscolineatus being recorded $87 \mathrm{~km}$ south of the border of the state of Paraná; the northernmost species is B. tridactylus (Tab. 1). Per relief unit, 15 species (three undescribed) occurs in Southern Serra do Mar and three in Leste Catarinense (Tab. 3; Fig. 1).

We were able to determine the extent of occurrence of 17 species ( $51.5 \%$ of all species with records at precise locations; Tab. 4). Two species of the didactylus group have the highest estimated extent of occurrence, with over 500 thousand ha, namely Brachycephalus sp. 1 and $B$. hermogenesi. On the other hand, estimates of extents of occurrence for all remaining species did 305 not reach 20 thousand ha. With proportionally intermediate extent of occurrence, there are tree 306 species from the ephippium group (B. garbeanus, B. margaritatus, and B. pitanga), with 307 estimates between 2-19 thousand ha, and five species from the pernix group (B. olivaceus, $B$. 308 brunneus, B. ferruginus, Brachycephalus sp. 6, and B. quiririensis), with estimates between 1-6 
309 thousand ha (Tab. 4). There are four species with small extent of occurrence, between 100-500

310 hectares, one from the didactylus group - B. pulex - and three from the pernix group - B. pernix,

311 B. izecksohni, and B. leopardus (Tab. 4). Finally, there are three species from the pernix group

312 with highly reduced extents of occurrence, namely B. tridactylus, B. fuscolineatus, and $B$.

313 boticario, with 41.42 ha, 23.63 ha, and 11.07 ha, respectively (Tab. 4).

314 Brachycephalus species are found from sea level to at least 1,900 m a.s.l. (Tab. 1 and 3).

315 The ephippium group was characterized by species with the broadest altitudinal amplitude $(1,700$

$316 \mathrm{~m}$; Tab. 4). The didactylus and pernix groups had similar altitudinal amplitude (1,110 $\mathrm{m}$ and

317 1,185 m, respectively; Tab. 4). However, the altitudinal occurrence of the didactylus group

318 started at sea level, whereas the pernix group began at mid-elevations (455 $\mathrm{m}$ a.s.l.; Tab. 4).

319 The altitudinal class with the highest species richness was 751-1,000 $\mathrm{m}$ a.s.l., with 21

320 species (three undescribed; Fig. 3A). The highest species richness for the didactylus group was

321 also found between 751-1,000 m a.s.1., including all four species of the group (one undescribed;

322 Fig. 3B). The highest richness of the ephippium group was evenly recorded between 751-1,000

$323 \mathrm{~m}$, comprising eight species (one undescribed; Fig. 3C). Finally, most species of the pernix group

324 were found between 1,001-1,250 $\mathrm{m}$ a.s.l., totalizing 10 species (three undescribed; Fig. 3D).

325 The species with the broadest altitudinal range was $B$. didactylus $(1,075 \mathrm{~m}$; starting at $35 \mathrm{~m}$

326 a.s.1.) and Brachycephalus sp. 1 (1,035 m; starting at $25 \mathrm{~m}$ a.s.1.), both included in the didactylus

327 group, and B. ephippium (1,050 m; starting from $200 \mathrm{~m}$ a.s.1.), included in the ephippium group

328 (Tab. 4). The largest altitudinal occurrence amplitude for species of the pernix group was

329 recorded in B. brunneus (535 m; starting at 1,095 $\mathrm{m}$ a.s.1.; Tab. 4). The lowest records for the

330 pernix group were at $845 \mathrm{~m}$ a.s.l. in the state of Paraná and at $455 \mathrm{~m}$ a.s.l. in the state of Santa

331 Catarina, southern Brazil (Tab. 1). This illustrates the tendency for the altitudinal distribution of

332 species of the pernix group to decrease with increasing latitude (Fig. 4).

333 Syntopy in Brachycephalus is rare, being reported for the didactylus and ephippium groups

334 in state of Rio de Janeiro and São Paulo, and for the didactylus and pernix groups in the state of

335 Paraná and Santa Catarina (Tab. 1). Between didactylus and ephippium groups, syntopy has been 336 reported in four localities: between B. didactylus and B. ephippium in the Reserva Ecológica Rio 337 das Pedras, Rio de Janeiro (Carvalho-e-Silva et al. 2008; Almeida-Santos et al. 2011; Rocha et 338 al. 2013); between B. didactylus and B. margaritatus in the Sacra Família do Tinguá, Rio de 339 Janeiro (Izecksohn 1971; Pombal 2001; Ribeiro et al. 2005; Alves et al. 2006, 2009; Silva et al. 
340 2007; Verdade et al. 2008; Clemente-Carvalho et al. 2009; Campos 2011; Pombal \& Izecksohn 341 2011; Pie et al. 2013); between B. didactylus and Brachycephalus sp. 2 in Theodoro de Oliveira, 342 Rio de Janeiro (Siqueira et al. 2011, 2013); and between B. hermogenesi and B. ephippium in the 343 Reserva Florestal de Morro Grande, São Paulo (Dixo \& Verdade 2006; Verdade et al. 2008).

344 Between didactylus and pernix groups, two cases of syntopy have been recorded (MRB, LFR \& 345 MRP, pers. obs.), one between Brachycephalus sp. 1 (didactylus group) and B. tridactylus, in 346 Reserva Particular do Patrimônio Natural Salto Morato, at 900 m a.s.l., and the another one 347 between Brachycephalus sp. 1 and B. olivaceus at Castelo dos Bugres, between 800-835 m a.s.1. 348 (Tab. 1).

349 Sympatry and possibly syntopy also between didactylus and ephippium groups was reported 350 in the state of São Paulo in two localities (Tab. 1): between B. hermogenesi and Brachycephalus 351 sp. 3 in the Reserva Biológica do Alto da Serra de Paranapiacaba (Verdade et al. 2008; Pie et al. 352 2013) and between B. hermogenesi and B. nodoterga in the Estação Biológica de Boracéia 353 (Pombal et al. 1998; Pombal 2001, 2010; Ribeiro et al. 2005; Alves et al. 2006, 2009; Pimenta et 354 al. 2007; Verdade et al. 2008; Haddad et al. 2010; Pombal \& Izecksohn 2011; Pie et al. 2013). A 355 sympatry may occur between species of a single group, particularly the ephippium group, in the 356 state of Rio de Janeiro (Tab. 1): between B. bufonoides and B. garbeanus in the Serra de Macaé 357 (Miranda-Ribeiro 1920; Pombal 2010; Pombal \& Izecksohn 2011) and between B. ephippium 358 and B. vertebralis in the Pedra Branca, municipality of Parati (Pombal 2001, 2010; Clemente359 Carvalho et al. 2009; Pombal \& Izecksohn 2011; Pie et al. 2013). Both need confirmation (see 360 Pombal 2001).

361

362 Discussion

363

364 The northernmost and southernmost relief units are poorly represented by records of 365 Brachycephalus, namely Pré-Litorâneas and Leste Catarinense, respectively. This suggests the 366 possibility that the genus occurs farther north and south from the most extreme records known 367 today (see Fig. 2). Interestingly, the potential distribution of Brachycephalus through 368 environmental niche modeling (Pie et al. 2013) is consistent with the possibility of a wider 369 distribution of the genus to the south of the current distribution, spreading widely through the 370 Leste Catarinense relief unit (see Figs 3a, b, e, f and Fig 4a of Pie et al [2013]). Forests at lower 
371 altitudes in the Pré-Litorâneas region are different from those in mountains at higher altitudes,

372 displaying, for example, little moss on tree trunks and scarce epiphytic plants (MRB \& RB-L

373 per. obs.). We believe it is possible that the occurrence of the genus in this relief unit is restricted

374 to mountains. Examples of locations of scarce humid mountains of this region can be seen in

375 Maurício et al. (2014), who mapped the occurrence of an endemic mountain bird to the Pré-

376 Litorâneas relief unit, the Scytalopus gonzagai. The environmental niche modeling of

377 Brachycephalus indeed indicates a small area of suitable habitats in this region (see Fig. $3 \mathrm{~b}$ of

378 Pie et al. [2013]).

379 The occurrence of B. ephippium in distinct relief units should be the subject of further 380 scrutiny. In particular, populations under that name might indeed represent cryptic species that 381 would have to be split (see also Dixo \& Verdade 2006; Silva et al. 2007; Clemente-Carvalho et 382 al. 2008, 2011b; Campos et al. 2010; Campos 2011; Siqueira et al. 2013; Trevine et al. 2014).

383 Similar conditions were detected in a montane bird, Scytalopus speluncae (taxonomy according 384 to Maurício et al. [2010]), which has to be split into several new species. In fact, the distribution 385 of S. speluncae is congruent with that of B. ephippium in some relief units (Mata et al. 2009; 386 MRB \& RB-L pers. obs.). The occurrence of B. ephippium around the city of São Paulo is of 387 particular interest, given this region is characterized as a contact between Serra da Mantiqueira 388 and Serra do Mar relief units (IBGE 1993).

$389 \quad$ For a long time, all known species of Brachycephalus of the pernix group had their 390 geographical distribution limited to a single "Serra", i.e., in a massif range with high altitudes, 391 isolated from other "Serras" by areas of lower altitudes. Pie et al. (2013) were the first to report 392 the occurrence of more than one species of the pernix group in a single "Serra", and here we 393 report on other similar situations. In addition, the present study is the first to report the 394 occurrence of a species of this group distributed in two "Serras". This is the case of B. brunneus, 395 distributed in Serra dos Órgãos (not to be confused with the homonym "Serra" of the state of Rio 396 de Janeiro) and Serra da Graciosa (Tab. 1). Distributions of more than one sepecies in a single 397 "Serra" involve the cases of B. ferruginus and Brachycephalus sp. 4, distributed in Serra do 398 Marumbi, and B. leopardus, B. auroguttatus, and B. quiririensis, distributed in Serra do 399 Araçatuba/Serra do Quiriri, a single mountain massif in the border of the states of Paraná and 400 Santa Catarina (Tab. 1). These cases do not represent syntopy because all of them are isolated 401 from each other by more than $3 \mathrm{~km}$. The occurrence of two species of the ephippium group in a 
402 single Serra are known for long time, i.e. 1920 (involving B. bufonoides and B. garbeanus; 403 Miranda-Ribeiro [1920]) and 2001 (involving B. ephippium and B. vertebralis; Pombal [2001]).

404 Is interesting to note that the species with low altitudinal records (and also with high 405 altitudinal amplitude of occurrence) are the ones of greatest extent of occurrence measured, 406 perhaps indicating that its relatively plastic condition provide them of major opportunity to 407 establishment through a continuous Atlantic Forest. In the other way, species with medium to 408 high lower limit of altitudinal occurrence, and also with moderate altitudinal amplitude of 409 occurrence, have very reduced extent of occurrence, indicating proportionaly reduced plasticity 410 and subjection of environmental and topographic constrains. In a study on a Neotropical bird, 411 Reinert et al. (2007) showed that a very detailed estimate of the species extent of occurrence 412 resulted in an area seven times greater than the area of occupancy, which underscores how much 413 the extent of occurrence of Brachycephalus could be overstimated. In comparison, the small 414 extent of occurrence of the Brachycephalus are not the smaller "range" of species in the worl; 415 among the samaller, there are an isopod and a fisch, with less than 0.01 ha of occurrence, each 416 (Brown et al. 1996). However, there are between the smallest "ranges" of vascular plants and 417 fishes of the world ( $<100 \mathrm{ha})$ and much smaller thant the smallest "ranges" of birds and 418 mammals of the world ( 1,000,000 ha; Brown et al. [1996]).

419 The altitudinal records indicate that the pernix and ephippium groups are indeed "montane 420 groups" (Figs. 1 and 3), even though the altitudinal amplitude of species of the ephippium group 421 might be underestimated. Occasional records below $500 \mathrm{~m}$ a.s.1. for species of both montane 422 groups do not mean that all "montane species" of the genus normally occur at lower altitudes, 423 with the absence of lower records resulting from sampling bias. Rather, one could expect that 424 species of the pernix group at higher latitudes would tend to be recorded at lower altitudes due to 425 climatic compensation. Moreover, local records at lower altitudes of species of montane groups 426 can be due to particular local conditions of high moisture resulting from peculiar topographical

427 features. Regardless of the extreme altitudinal records, each species must have an altitudinal 428 range that corresponds to its climatic optimum (see Fig. 1). Studies estimating abundance along 429 altitudinal transects can be used not only to determine altitudinal ranges but also the climatic 430 optimum for each species. These data are of particular interest in the context of long-term studies 431 to assess the impact of climatic changes, with gradual modification in the abundances and even 432 changes in the altitudinal range being expected over time (see Corn 2005; Jump et al. 2012). 
433 All records of pernix group species in the state of Paraná were either made in cloud forests 434 ("Floresta Ombrófila Densa Alto-montana" sensu Veloso et al. [1991]) or in the transition zones 435 between cloud forest and montane forests ("Floresta Ombrófila Densa Montana"). The only 436 exception is B. tridactylus, which occurs in montane forest (this study, since there is no available 437 description for the forest type in the species description by Garey et al. [2012]). Cloud or elfin 438 forests are pygmy tropical forests that occur in highly humid regions at the cloud level, between 4391,000 to 2,500 m a.s.1. (Walter 1977). In the state of Paraná, these forests occur from $900 \mathrm{~m}$ to 440 about 1,850 m a.s.1. (Struminski 1997; Bornschein et al. 2012). The lowest record of B. pombali 441 (845 $\mathrm{m}$ a.s.1.), in the transition between cloud forest and montane forest, probably represents the 442 lowest altitude of this transition in the state of Paraná. In Santa Catarina, species from the pernix 443 group occur in cloud forests, montane forests, and in the transition between them. The only 444 known exception of forest habitat in the pernix group involves the observation of B. izecksohni, 445 also in herbaceous montane fields ("campos de altitude" or "Refúgio Vegetacional", sensu 446 Veloso et al. [1991]; MRB pers. obs.).

447 The few cases of syntopy between species, not only show little altitudinal overlap, but also 448 involve species of different groups, consistent with the notion that closely related species remain 449 allopatric. Localities with sympatry and syntopy are particularly interesting for further studies 450 related to the altitudinal distribution of species. On the other hand, sympatry between species of 451 the groups ephippium and pernix is not expected, given that a gap of $208 \mathrm{~km}$ occurs between 452 species of these groups. It is interesting to note that only the montane species groups, i.e. 453 ephippium and pernix, are highly species-rich, yet they tend not to show sympatry (although 454 there are some species distributed very close each other, and that there are cases of distinct 455 species occurring in a single "Serra"). We believe that these conditions suggest that these groups 456 evolved in allopatry and/or parapatry while the Atlantic Forest experienced retraction and 457 isolation as island between grasslands. During the Quaternary, climatic conditions changed 458 cyclically from cold and dry to warmer and wet periods, and these shifts were responsible for the 459 cyclical retraction and expansion of forest coverage, respectively (e.g. Behling \& Lichte 1997; 460 Behling et al. 2002, 2005, 2007; Behling 2007; Langone et al. 2008; Behling \& Safford 2010; 461 Enters et al. 2010; Hessler et al. 2010). In colder climates, montane forests may have migrated to 462 lower altitudes, allowing species of Brachycephalus to disperse. In subsequent warmer and wet 
463 climate, the montane forest may have migrated to higher altitudes, isolating populations of 464 Brachycephalus and favoring speciation.

465 In relation to the species distributed close to each other or in single "Serras", without 466 apparent geographic barriers, it is possible that the expansion and retraction of forests did not 467 occur homogeneously across attitudinal quotas, but it might have occurred as isolated patches 468 even in restricted areas. In areas where climatic conditions favored the return of a vast forest 469 cover, geographically close species would have lost the corresponding environmental barriers, remaining allopatric probably due to ecological requirements. The most notable case of proximity between species occurs in northeastern state of São Paulo, where higher mountains are absent and five species occur in a single plateau (B. crispus, B. guarani, B. pitanga, B. toby, and $B$. vertebralis). In this region, the forests may have been confined in valleys during the periods of retraction in the forest distribution.

In conclusion, Brachycephalus is restricted to the eastern portion of the Atlantic Forest biome, with species occurring in allopatry or at least in parapatry, with rare cases of syntopy. The species of the genus are segregated in three groups of species, with one of them (didactylus) including species that respond differently to altitude, occurring in lower altitudes and having greater geographic distributions, being much more ecologicaly tolerant and plastic. Species from the remaining groups (ephippium and pernix) depend on high altitude conditions and can be found locally in lower altitudes, probably in response to particular microclimatic conditions. Sympatric species include members of distinct species groups and are in contact only in the altitudinal limits of each other (higher limit for the "lowland" species and lower limit for the "montane" species). Apart from a few species, most of them have restricted extents of occurrence, to the point that many are microendemic, occurring in mountain tops with a total extent of occurrence comparable to the smallest range from species around world. The microhabitat requeriments of the species can prevent more realistic estimatives of extent of occurrence, with traditional methodologies possibly resulting in substantial bias. This same feature makes the species of particular interest to monitor climate change through their abundances along altitudinal gradients. The genus also can be used as excellent model to infer historical environmental changes due past climatic changes, given that they are thought to have resulted from vicariant processes following upward migration of montane forests through altitudinal ranges, in past warm and wet climates. 
494

495

496

497

498

499

500

501

502

503

504

505

506

507

508

509

510

511

512

513

514

515

516

517

518

519

520

521

522

523

524

\section{Acknowledgements}

We thank Magno V. Segalla and Camila R. Alves for valuable assistance during fieldwork. Claudia Golec helped in the compilation of bibliography. Two anonymous referees improved the manuscript with valuable comments and suggestions.

\section{References}

Abegg, A.D.; Ortiz, F.R.; Rocha, B. \& Condez, T.H. 2015. A new record for Brachycephalus nodoterga (Amphibia, Anura, Brachycephalidae) in the state of São Paulo, Brazil. Check List 11: 1769.

Almeida, F.F.M. de \& Carneiro, C.dal R. 1998. Origem e evolução da Serra do Mar. Revista Brasileira de Geociências 28: 135-150.

Almeida-Santos, M.; Siqueira, C.C.; Van Sluys, M. \& Rocha, C.F.D. 2011. Ecology of the Brazilian flea frog Brachycephalus didactylus (Terrarana: Brachycephalidae). Journal of Herpetology 45: 251-255.

Alves, A.C.R.; Ribeiro, L.F.; Haddad, C.F.B. \& Reis, S.F. dos. 2006. Two new species of Brachycephalus (Anura: Brachycephalidae) from the Atlantic Forest in Paraná State, southern Brazil. Herpetologica 62: 221-233.

Alves, A.C.R.; Sawaya, R.J.; Reis, S.F. dos \& Haddad, C.F.B. 2009. New species of Brachycephalus (Anura: Brachycephalidae) from the Atlantic Rain Forest in São Paulo State, Southeastern Brazil. Journal of Herpetology 43: 212-219.

Amaro, R.C.; Rodrigues, M.T.; Yonenaga-Yassuda, Y. \& Carnaval, A.C. 2012. Demographic processes in the montane Atlantic rainforest: Molecular and cytogenetic evidence from the endemic frog Proceratophrys boiei. Molecular Phylogenetics and Evolution 62: 880-888.

Ananias, F.; Giaretta, A.A. \& Recco-Pimentel, S.M. 2006. Cytogenetics of Brachycephalus ephippium (Anura, Brachycephalidae) with comments on its relationship to the Bufonidae. Amphibia-Reptilia 27: 121-125.

Araújo, C.B. de; Guerra, T.J.; Amatuzzi, M.C.O. \& Campos, L.A. 2012. Advertisement and territorial calls of Brachycephalus pitanga (Anura: Brachycephalidae). Zootaxa 3302: 6667. 
525 Behling, H. 2007. Late Quaternary vegetation, fire and climate dynamics of Serra do Araçatuba 526 in the Atlantic coastal mountains of Paraná State, southern Brazil. Vegetation History and 527 Archaeobotany 16: 77-85.

528 Behling, H.; Arz, H.W.; Pätzold, J.; \& Wefer, G. 2002. Late Quaternary vegetational and climate

529

530

531

532

533

534

535

536

537

538

539

540

541

542

543

544

545

546

547

548

549

550

551

552

553

554 dynamics in southeastern Brazil, inferences from marine cores GeoB 3229-2 and GeoB 3202-1. Palaeogeography, Palaeoclimatology, Palaeoecology 179: 227-243.

Behling, H.; Dupont, L.; Safford, H. D. \& Wefer, G. 2007. Late Quaternary vegetation and climate dynamics in the Serra da Bocaina, southeastern Brazil. Quaternary International 161: 22-31.

Behling, H. \& Lichte, M. 1997. Evidence of dry and cold climatic conditions at glacial times in tropical southeastern Brazil. Quaternary Research 48: 348-358.

Behling, H.; Pillar, V. DePatta \& Bauermann, S.G. 2005. Late Quaternary grassland (Campos), gallery forest, fire and climate dynamics, studied by pollen, charcoal and multivariate analysis of the São Francisco de Assis core in western Rio Grande do Sul (southern Brazil). Review of Palaeobotany and Palynology 133: 235-248.

Behling, H. \& Safford, H.D. 2010. Late-glacial and Holocene vegetation, climate and fire dynamics in the Serra dos Órgãos, Rio de Janeiro State, southeastern Brazil. Global Change Biology 16: 1661-1671.

Bornschein, M.R.; Belmonte-Lopes, R.; Ribeiro, L.F.; Maurício, G.N. \& Pie, M.R. 2015. Rectification of the position of the type locality of Brachycephalus tridactylus (Anura: Brachycephalidae), a recently described species from southern Brazil. Zootaxa 4007: 149_ 150.

Bornschein, M.R.; Corrêa, L.; Belmonte-Lopes, R.; Klemann Júnior, L.; Cáceres, N.C. \& Pie, M.R. 2012. The use of highlands by the Lowland Tapir (Tapirus terrestris) in the southern Brazilian Atlantic Forest. Neotropical Biology and Conservation 7: 210-213.

Brown, J.H.; Stevens, G.C. \& Kaufman, D.M. 1996. The geographic range: size, shape, boundaries, and internal structure. Annual Review of Ecology and Systematics 27: 597-623. Brunes, T.O.; Sequeira, F.; Haddad, C.F.B. \& Alexandrino, J. 2010. Gene and species trees of a Neotropical group of treefrogs: genetic diversification in the Brazilian Atlantic Forest and the origin of a polyploid species. Molecular Phylogenetics and Evolution 57: 1120-1133. 
555 Campos, L.A. 2011. Sistemática filogenética do gênero Brachycephalus Fitzinger, 1826 (Anura:

556

557

558

559

560

561

562

563

564

565

566

567

568

569

570

571

572

573

574

575

576

577

578

579

580

581

582

583

584

Brachycephalidae) com base em dados morfológicos. Thesis. Brasília, Universidade de Brasília, $67 \mathrm{p}$.

Campos, L.A.; Silva, H.R. da \& Sebben, A. 2010. Morphology and development of additional bony elements in the genus Brachycephalus (Anura: Brachycephalidae). Biological Journal of the Linnean Society 99: 752-767.

Carnaval, A.C.; Hickerson, M.J.; Haddad, C.F.B.; Rodrigues, M.T. \& Moritz, C. 2009. Stability predicts genetic diversity in the Brazilian Atlantic Forest hotspot. Science 323: 785-789.

Carvalho-e-Silva, A.M.T. de; Silva, G.R. da \& Carvalho-e-Silva, S.P. de. 2008. Anuros da Reserva Rio das Pedras, Mangaratiba, RJ, Brasil. Biota Neotropica 8: 199-209.

Clemente-Carvalho, R.B.G.; Alves, A.C.R.; Perez, S.I.; Haddad C.F.B. \& Reis, S.F. dos. 2011 b. Morphological and molecular variation in the Pumpkin Toadlet, Brachycephalus ephippium (Anura: Brachycephalidae). Journal of Herpetology 45: 94-99.

Clemente-Carvalho, R.B.G.; Antoniazzi, M.M.; Jared, C.; Haddad, C.F.B.; Alves, A.C.R.; Rocha, H.S.; Pereira, G.R.; Oliveira, D.F.; Lopes, R.T. \& Reis, S.F. dos. 2009. Hyperossification in miniaturized toadlets of the genus Brachycephalus (Amphibia: Anura: Brachycephalidae): Microscopic structure and macroscopic patterns of variation. Journal of Morphology 270: 1285-1295.

Clemente-Carvalho, R.B.G.; Klaczko, J.; Perez, S.I.; Alves, A.C.R.; Haddad, C.F.B. \& Reis, S.F. dos. 2011a. Molecular phylogenetic relationships and phenotypic diversity in miniaturized toadlets, genus Brachycephalus (Amphibia: Anura: Brachycephalidae). Molecular Phylogenetics and Evolution 61: 79-89.

Clemente-Carvalho, R.B.G.; Giaretta, A.A.; Condez, T.H.; Haddad, C.F.B. \& Reis, S.F. dos. 2012. A new species of miniaturized toadlet, genus Brachycephalus (Anura:

Brachycephalidae), from the Atlantic Forest of southeastern Brazil. Herpetologica 68: 365374.

Clemente-Carvalho, R.B.G.; Monteiro, L.R.; Bonato, V.; Rocha, H.S.; Pereira, G.R.; Oliveira, D.F.; Lopes, R.T.; Haddad, C.F.B.; Martins, E.G. \& Reis, S.F. dos. 2008. Geographic variation in cranial shape in the Pumpkin Toadlet (Brachycephalus ephippium): a geometric analysis. Journal of Herpetology 42: 176-185. 
585 Clemente-Carvalho, R.B.G.; Perez, S.I.; Tonhatti, C.H.; Condez, T.H.; Sawaya, R.J.; Haddad, 586 C.F.B. \& Reis, S.F. dos. 2016. Boundaries of morphological and molecular variation and the 587 distribution range of a miniaturized froglet, Brachycephalus nodoterga (Anura:

588 Brachycephalidae). Journal of Herpetology 50: 169-178.

589 Condez, T.H.; Sawaya, R.J. \& Dixo, M. 2009. Herpetofauna dos remanescentes de Mata 590 Atlântica da região de Tapiraí e Piedade, SP, sudeste do Brasil. Biota Neotropica 9: 157591185.

592 Condez, T.H.; Clemente-Carvalho, R.B.G.; Haddad, C.F.B. \& Reis, S.F. dos. 2014. A new 593 species of Brachycephalus (Anura: Brachycephalidae) from the highlands of the Atlantic 594 Forest, southeastern Brazil. Herpetologica 70: 89-99.

595 Corn, P.S. 2005. Climate change and amphibians. Animal Biodiversity and Conservation 28: 59$596 \quad 67$.

597 Cruz, C.A.G. \& Feio, R.N. 2007. Endemismos em anfíbios em áreas de altitudes na Mata

598

599

600

601

602

603

604

605

606

607

608

609

610

611

612

613 Atlântica no sudeste do Brasil. In: Nascimento, L.B. \& Oliveira, M.E. (Eds), Herpetologia no Brasil II. Belo Horizonte, Sociedade Brasileira de Herpetologia, pp. 117-126.

Cunha, A.K.; Oliveira, I.S. de \& Hartmann, M.T. 2010. Anurofauna da Colônia Castelhanos, na Área de Proteção Ambiental de Guaratuba, Serra do Mar paranaense, Brasil. Biotemas 23: $123-134$.

Dixo, M. \& Verdade, V.K. 2006. Herpetofauna de serrapilheira da Reserva Florestal de Morro Grande, Cotia (SP). Biota Neotropica 6: 1-20.

Dorigo, T.A.; Siqueira, C.C.; Vrcibradic, D.; Maia-Carneiro, T.; Almeida-Santos, M. \& Rocha, C.F.D. 2012. Ecological aspects of the pumpkin toadlet, Brachycephalus garbeanus Miranda-Ribeiro, 1920 (Anura: Neobatrachia: Brachycephalidae), in a highland forest of southeastern Brazil. Journal of Natural History 46: 2497-2507.

Enters, D.; Behling, H.; Mayr, C.; Dupont, L. \& Zolitschka, B. 2010. Holocene environmental dynamics of south-eastern Brazil recorded in laminated sediments of Lago Aleixo. Journal of Paleolimnology 44: 265-277.

Firkowski, C.R. 2013. Diversification and microendemism in montane refugia from the Brazilian Atlantic Forest. Dissertation. Curitiba, Universidade Federal do Paraná, 59 p. 
614 Fontoura, P.L.; Ribeiro L.F. \& Pie, M.R. 2011. Diet of Brachycephalus brunneus (Anura: 615 Brachycephalidae) in the Atlantic Rainforest of Paraná, southern Brazil. Zoologia 28: 687$616 \quad 689$

617 Frost, D.R. 2015. Amphibian species of the world. An online reference. Version 6.0 Eletronic 618 Available from http://research.amnh.org/herpetology/amphibia/index.html (accessed 12 619 September 2015).

620 Garey, M.V.; Lima, A.M.X.; Hartmann, M.T. \& Haddad, C.F.B. 2012. A new species of

621

622

623

624

625

626

627

628

629

630

631

632

633

634

635

636

637

638

639

640

641

642

643

644 miniaturized toadlet, genus Brachycephalus (Anura: Brachycephalidae), from southern Brazil. Herpetologica 68: 266-271.

Giaretta, A.A. 1999. Diversidade e densidade de anuros de serapilheira num gradiente altitudinal na mata atlântica costeira. Thesis. Campinas, Universidade Estadual de Campinas, 140 p.

Giaretta, A.A.; Facure, K.G.; Sawaya, R.J.; Meyer, J.H. de M. \& Chemin, N. 1999. Diversity and abundance of litter frogs in a montane forest of Southeastern Brazil: Seasonal and altitudinal changes. Biotropica 31: 669-674.

Giaretta, A.A. \& Sawaya, R.J. 1998. Second species of Psyllophryne (Anura: Brachycephalidae). Copeia 1998: 985-987.

Giaretta, A.A.; Sawaya, R.J.; Machado, G.; Araújo, M.S.; Facure, K.G.; Medeiros, H.F. de \& Nunes, R. 1997. Diversity and abundance of litter frogs at altitudinal sites at Serra do Japi, Southeastern Brazil. Revista Brasileira de Zoologia 14: 341-346.

Giarla, T.C.; Voss, R.S. \& Jansa, S.A. 2014. Hidden diversity in the Andes: comparison of species delimitation methods in montane marsupials. Molecular Phylogenetics and Evolution 70: 137-151.

Haddad, C.F.B.; Alves, A.C.R.; Clemente-Carvalho, R.B.G. \& Reis, S.F. dos. 2010. A new species of Brachycephalus from the Atlantic Rain Forest in São Paulo state, southeastern Brazil (Amphibia: Anura: Brachycephalidae). Copeia 2010: 410-420.

Hanken, J. \& Wake, D.B. 1993. Miniaturization of body size: Organismal consequences and evolutionary significance. Annual Review of Ecology and Systematics 24: 501-519.

Hessler, I.; Dupont, L.; Bonnefille, R.; Behling, H.; González, C.; Helmens, K.F.; Hooghiemstra, H.; Lebamba, J.; Ledru, M.-P.; Lézine, A.-M.; Maley, J.; Marret, F. \& Vincens, A. 2010. Millennial-scale changes in vegetation records from tropical Africa and South America during the last glacial. Quaternary Science Reviews 29: 2882-2899. 
645 IBAMA. 2007. Sistema compartilhado de informações ambientais - Instituto Brasileiro do Meio

646 Ambiente e dos Recursos Naturais Renováveis. Available from

647 http://siscom.ibama.gov.br/shapes (accessed 15 April 2012)

648 IBGE. 1993. Mapa de unidades de relevo do Brasil. Rio de Janeiro, Instituto Brasileiro de 649 Geografia e Estatística - IBGE.

650 IBGE. 2006. Mapa de unidades de relevo do Brasil. Rio de Janeiro, Instituto Brasileiro de 651 Geografia e Estatística - IBGE.

652 IUCN. 2012. IUCN Red List categories and criteria: Version 3.1. Second edition. Gland, 653 Switzerland and Cambridge, International Union for Conservation of Nature - IUCN. 654 Izecksohn, E. 1971. Novo gênero e nova espécie de Brachycephalidae do Estado do Rio de 655 Janeiro, Brasil. Boletim do Museu Nacional, Zoologia 280: 1-12.

656 Jump, A.S.; Huang, T.J. \& Chou, C.H. 2012. Rapid altitudinal migration of mountain plants in 657 Taiwan and its implications for high altitude biodiversity. Ecography 35: 204-210.

658 Kaplan, K. 2002. Histology of the anteroventral part of the breast-shoulder apparatus of 659 Brachycephalus ephippium (Brachycephalidae) with comments on the validity of the genus 660 Psyllophryne (Brachycephalidae). Amphibia-Reptilia 23: 225-227.

661 Knyazhnitskiy, O.V.; Monk, R.R.; Parker, N.C. \& Baker, R.J. 2000. Assignment of Global 662 Information System coordinates to classical museum localities for relational database 663 analyses. Occasional Papers 199: 1-15.

664 Langone, J.A.; Segalla, M.V.; Bornschein, M. \& Sá, R.O. de. 2008. A new reproductive mode in 665 the genus Melanophryniscus Gallardo, 1961 (Anura: Bufonidae) with description of a new 666 667 668 669 670 species from the state of Paraná, Brazil. South American Journal of Herpetology 3: 1-9.

Maack, R. 1981. Geografia física do estado do Paraná. Rio de Janeiro, Livraria José Olympio Editora, $450 \mathrm{p}$.

Mariotto, L.R. 2014. Anfíbios de um gradiente altitudinal em mata atlântica. Dissertation.

673 Curitiba, Universidade Federal do Paraná, 174 p.

Mata, H.; Fontana, C.S.; Maurício, G.N.; Bornschein, M.R.; Vasconcelos, M.F. de \& Bonatto, 674 S.L. 2009. Molecular phylogeny and biogeography of the eastern Tapaculos (Aves: Rhinocryptidae: Scytalopus, Eleoscytalopus): Cryptic diversification in Brazilian Atlantic Forest. Molecular Phylogenetics and Evolution 53: 450-462. 
675 Maurício, G.N.; Belmonte-Lopes, R.; Pacheco, J.F.; Silveira, L.F.; Whitney, B.M. \& Bornschein, 676 M.R. 2014. Taxonomy of "Mouse-colored Tapaculos" (II): An endangered new species from 677 the montane Atlantic Forest of southern Bahia, Brazil (Passeriformes: Rhinocryptidae: 678 Scytalopus). The Auk 131: 643-659.

679 Maurício, G.N.; Bornschein, M.R.; Vasconcelos, M.F. de; Whitney, B.M.; Pacheco, J.F. \& 680 Silveira, L.F. 2010. Taxonomy of "Mouse-colored Tapaculos". I. On the application of the 681 name Malacorhynchus speluncae Ménétriés, 1835 (Aves: Passeriformes: Rhinocryptidae). 682 Zootaxa 2518: 32-48.

683

684

685

686

687

688

689

690

691

692

693

694

695

696

697

698

699

700

701

702

703

704

705

Miranda-Ribeiro, A. de. 1920. Os brachycephalideos do Museu Paulista (com tres especies novas). Revista do Museu Paulista 12: 306-318.

Mohr, C. 1947. Table of equivalent populations of North American small mammals. American Midland Naturalist 37: 223-249.

Napoli, M.F.; Caramaschi, U.; Cruz, C.A.G. \& Dias, I.R. 2011. A new species of flea-toad, genus Brachycephalus Fitzinger (Amphibia: Anura: Brachycephalidae), from the Atlantic rainforest of southern Bahia, Brazil. Zootaxa 2739: 33-40.

Oliveira, E.G. de. 2013. História natural de Brachycephalus pitanga no Núcleo Santa Virgínia, Parque Estadual da Serra do Mar, Estado de São Paulo. Dissertation. Rio Claro, Universidade Estadual Paulista "Júlio de Mesquita Filho", 78 p.

Oliveira, E.G. de \& Haddad, C.F.B. 2015. Diet seasonality and feeding preferences of Brachycephalus pitanga (Anura: Brachycephalidae). Journal of Herpetology 49: 252-256. Oliveira, A.K.C. de; Oliveira, I.S. de; Hartmann, M.T.; Silva, N.R. da \& Toledo, L.F. 2011. Amphibia, Anura, Brachycephalidae, Brachycephalus hermogenesi (Giaretta and Sawaya, 1998): New species record in the state of Paraná, southern Brazil and geographic distribution map. Check List 7: 17-18.

Oliveira, J.C.F. de; Coco, L.; Pagotto, R.V.; Pralon, E.; Vrcibradic, D.; Pombal Jr., J.P. \& Rocha, C.F.D. 2012. Amphibia, Anura, Brachycephalus didactylus (Izecksohn, 1971) and Zachaenus parvulus (Girard, 1853): Distribution extension. Check List 8: 242-244.

Oliveira, J.C.F.; Pralon, E.; Coco, L.; Pagotto, R.V. \& Rocha, C.F.D. 2013. Environmental humidity and leaf-litter depth affecting ecological parameters of a leaf-litter frog community in an Atlantic Rainforest area. Journal of Natural History 47: 2115-2124.

Padial, J.M.; Grant, T. \& Frost, D.R. 2014. Molecular systematics of terraranas (Anura: 
706

707

708

709

710

711

712

713

714

715

716

717

718

719

720

721

722

723

724

725

726

727

728

729

730

731

732

733

734

735

736

Brachycephaloidea) with an assessment of the effects of alignment and optimality criteria. Zootaxa 3825: 1-132.

Páez-Moscoso, D.J. \& Guayasamin, J.M. 2012. Species limits in the Andean toad genus

Osornophryne (Bufonidae). Molecular Phylogenetics and Evolution 65: 805-822.

Pereira, M. dos S.; Candaten, A.; Milani, D.; Oliveira, F.B. de; Gardelin, J.; Rocha, C.F.D. \& Vrcibradic, D. 2010. Brachycephalus hermogenesi. Herpetological Review 41: 506.

Pie, M.R.; Meyer, A.L.S.; Firkowski, C.R.; Ribeiro, L.F. \& Bornschein, M.R. 2013.

Understanding the mechanisms underlying the distribution of microendemic montane frogs (Brachycephalus spp., Terrarana: Brachycephalidae) in the Brazilian Atlantic Rainforest. Ecological Modelling 250: 165-176.

Pie, M.R. \& Ribeiro, L.F. 2015. A new species of Brachycephalus (Anura: Brachycephalidae) from the Quiriri mountain range of southern Brazil. PeerJ 3: e1179.

Pimenta, B.V.S.; Bérnils, R.S. \& Pombal Jr., J.P. 2007. Amphibia, Anura, Brachycephalidae, Brachycephalus hermogenesi: Filling gap and geographic distribution map. Check List 3: 277-279.

Pires Jr., O.R.; Sebben, A.; Schwartz, E.F.; Bloch Jr., C.; Morales, R.A.V. \& Schwartz, C.A. 2003. The occurrence of 11-oxotetrodotoxin, a rare tetrodotoxin analogue, in the brachycephalidae (sic) frog Brachycephalus ephippium. Toxicon 42: 563-566.

Pires Jr., O.R.; Sebben, A.; Schwartz, E.F.; Largura, S.W.R.; Bloch Jr., C.; Morales, R.A.V. \& Schwartz, C.A. 2002. Occurrence of tetrodotoxin and its analogues in the Brazilian frog Brachycephalus ephippium (Anura: Brachycephalidae). Toxicon 40: 761-766.

Pires Jr, O.R.; Sebben, A.; Schwartz, E.F.; Morales, R.A.V.; Bloch Jr, C. \& Schwartz, C.A. 2005. Further report of the occurrence of tetrodotoxin and new analogues in the Anuran family Brachycephalidae. Toxicon 45: 73-79.

Pombal Jr., J.P. 1999. Oviposição e desenvolvimento de Brachycephalus ephippium (Spix) (Anura, Brachycephalidae). Revista Brasileira de Zoologia 16: 967-976.

Pombal Jr., J.P. 2001. A new species of Brachycephalus (Anura: Brachycephalidae) from Atlantic Forest of southeastern Brazil. Amphibia-Reptilia 22: 179-185.

Pombal Jr., J.P. 2010. A posição taxonômica das "variedades" de Brachycephalus ephippium (Spix, 1824) descritas por Miranda-Ribeiro, 1920 (Amphibia, Anura, Brachycephalidae). Boletim do Museu Nacional, Zoologia 526: 1-12. 
737 Pombal Jr., J.P. \& Gasparini, J.L. 2006. A new Brachycephalus (Anura: Brachycephalidae) from

738

739

740

741

742

743

744

745

746

747

748

749

750

751

752

753

754

755

756

757

758

759

760

761

762

763

764

765

766

767

the Atlantic Rainforest of Espírito Santo, southeastern Brazil. South American Journal of Herpetology 1: 87-93.

Pombal Jr., J.P. \& Izecksohn, E. 2011. Uma nova espécie de Brachycephalus (Anura, Brachycephalidae) do Estado do Rio de Janeiro. Papéis Avulsos de Zoologia 51: 443-451.

Pombal Jr., J.P.; Sazima, I. \& Haddad, C.F.B. 1994. Breeding behavior of the pumpkin toadlet, Brachycephalus ephippium (Brachycephalidae). Journal of Herpetology 28: 516-519.

Pombal Jr., J.P.; Wistuba, E.M. \& Bornschein, M.R. 1998. A new species of brachycephalid (Anura) from the Atlantic Rain Forest of Brazil. Journal of Herpetology 32: 70-74.

Reinert, B.L., Bornschein, M.R. \& Firkowski, C. 2007. Distribuição, tamanho populacional, hábitat e conservação do bicudinho-do-brejo Stymphalornis acutirostris Bornschein, Reinert e Teixeira, 1995 (Thamnophilidae). Revista Brasileira de Ornitologia 15: 493-519.

Ribeiro, R. da S. 2006. Ecologia alimentar das quatro espécies dominantes da anurofauna de serapilheira em um gradiente altitudinal na ilha de São Sebastião, SP. Dissertation. Rio Claro, Universidade Estadual Paulista "Júlio de Mesquita Filho", 124 p.

Ribeiro, L.F.; Alves, A.C.R. \& Haddad, C.F.B. 2005. Two new species of Brachycephalus Günther, 1858 from the state of Paraná, southern Brazil (Amphibia, Anura, Brachycephalidae). Boletim do Museu Nacional, Zoologia 519: 1-18.

Ribeiro, L.F.; Bornschein, M.R.; Belmonte-Lopes, R.; Firkowski, C.R.; Morato, S.A.A. \& Pie, M.R. 2015. Seven new microendemic species of Brachycephalus (Anura: Brachycephalidae) from southern Brazil. PeerJ 3: e1011.

Ribeiro, L.F.; Ströher, P.R.; Firkowski, C.R.; Cini, F.A.; Bornschein, M.R. \& Pie, M.R. 2014. Brachycephalus pernix (Anura: Brachycephalidae), a new host of Ophiotaenia (Eucestoda: Proteocephalidea). Herpetology Notes 7: 291-294.

Rocha, C.F.D.; Van Sluys, M.; Alves, M.A.S.; Bergallo, H.G. \& Vrcibradic, D. 2000. Activity of leaf-litter frogs: When should frogs be sampled? Journal of Herpetology 34: 285-287.

Rocha, C.F.D.; Van Sluys, M.; Alves, M.A.S.; Bergallo, H.G. \& Vrcibradic, D. 2001. Estimates of forest floor litter frog communities: A comparison of two methods. Austral Ecology 26: $14-21$.

Rocha, C.F.D.; Vrcibradic, D.; Kiefer, M.C.; Almeida-Gomes, M.; Borges-Junior, V.N.T.; Menezes, V.A.; Ariani, C.V.; Pontes, J.A.L.; Goyannes-Araújo, P.; Marra, R.V.; Guedes, 
768

769

770

771

772

773

774

775

776

777

778

779

780

781

782

783

784

785

786

787

788

789

790

791

792

793

794

795

796

D.M.; Siqueira, C. da C. \& Van Sluys, M. 2013. The leaf-litter frog community from Reserva Rio das Pedras, Mangaratiba, Rio de Janeiro State, Southeastern Brazil: species richness, composition and densities. North-Western Journal of Zoology 9: 151-156.

Roderjan, C.V. 1994. O gradiente da Floresta Ombrófila Densa no Morro Anhangava, Quatro Barras, PR - aspectos climáticos, pedológicos e fitossociológicos. Thesis. Curitiba, Universidade Federal do Paraná, 118 p.

Santos-Pereira, M.; Candaten, A.; Milani, D.; Oliveira, F.B.; Gardelin, J. \& Rocha, C.F.D. da. 2011. Seasonal variation in the leaf-litter frog community (Amphibia: Anura) from an Atlantic Forest area in the Salto Morato Natural Reserve, southern Brazil. Zoologia 28: 755761.

Schwartz, C.A.; Castro, M. de S.; Pires Júnior, O.R.; Maciel, N.M.; Schwartz, E.N.F. \& Sebben, A. 2007. Princípios bioativos da pele de anfíbios: panorama atual e perspectivas. In: Nascimento, L.B. \& Oliveira, M.E. (Eds), Herpetologia no Brasil II. Belo Horizonte, Sociedade Brasileira de Herpetologia, pp. 146-168.

Sebben, A.; Schwartz, C.A.; Valente, D. \& Mendes, E.G. 1986. A tetrodotoxin-like substance found in the Brazilian frog Brachycephalus ephippium. Toxicon 24: 799-806.

Silva, H.R. da; Campos, L.A. \& Sebben, A. 2007. The auditory region of Brachycephalus and its bearing on the monophyly of the genus (Anura: Brachycephalidae). Zootaxa 1422: 59-68.

Siqueira, C.C.; Vrcibradic, D.; Almeida-Gomes, M.; Borges-Jr., V.N.T.; Almeida-Santos, P.; Almeida-Santos, M.; Ariani, C.V.; Guedes, D.M.; Goyannes-Araújo, P.; Dorigo, T.A.; Van Sluys, M. \& Rocha, C.F.D. 2009. Density and richness of the leaf litter frogs of an Atlantic Rainforest area in Serra dos Órgãos, Rio de Janeiro State, Brazil. Zoologia 26: 97-102.

Siqueira, C.C.; Vrcibradic, D.; Dorigo, T.A. \& Rocha, C.F.D. 2011. Anurans from two highelevation areas of Atlantic Forest in the state of Rio de Janeiro, Brazil. Zoologia 28: 457464.

Siqueira, C.C.; Vrcibradic, D.; Nogueira-Costa, P.; Martins, A.R.; Dantas, L.; Gomes, V.L.R.; Bergallo, H.G. \& Rocha, C.F.D. 2014. Environmental parameters affecting the structure of leaf-litter frog (Amphibia: Anura) communities in tropical forests: a case study from an Atlantic Rainforest area in southeastern Brazil. Zoologia 31: 147-152. 
797 Siqueira, C.C.; Vrcibradic, D. \& Rocha, C.F.D. 2013. Altitudinal records of data-deficient and

798

799

800

801

802

803

804

805

806

807

808

809

810

811

812

813

814

815

816

817

818

819

820

821

822

823

824

825

826

827 threatened frog species from the Atlantic Rainforest of the Serra dos Órgãos mountains, in southeastern Brazil. Brazilian Journal of Biology 73: 229-230.

Struminski, E. 1997. Parque Estadual Pico do Marumbi, estudo de vegetação e análise de áreas de instabilidade ambiental. Agrárias 16: 107-119.

Tandel, M. da C.F.F.; Loibel, S.; Oliveira, E.G. de \& Haddad, C.F.B. 2014. Diferenciação de 3 tipos de vocalizações (cantos) na espécie Brachycephalus pitanga. Revista da Estatística da Universidade Federal de Ouro Preto 3: 374-386.

Thomé, M.T.C.; Zamudio, K.R.; Giovanelli, J.G.R.; Haddad, C.F.B.; Baldissera Jr., F.A. \& Alexandrino, J. 2010. Phylogeography of endemic toads and post-Pliocene persistence of the Brazilian Atlantic Forest. Molecular Phylogenetics and Evolution 55: 1018-1031.

Trevine, V.; Forlani, M.C.; Haddad, C.F.B. \& Zaher, H. 2014. Herpetofauna of Paranapiacaba: expanding our knowledge on a historical region in the Atlantic forest of southeastern Brazil. Zoologia 31: 126-146.

Van Sluys, M.; Vrcibradic, D.; Alves, M.A.S.; Bergallo, H.G. \& Rocha, C.F.D. 2007. Ecological parameters of the leaf-litter frog community of an Atlantic Rainforest area at Ilha Grande, Rio de Janeiro state, Brazil. Austral Ecology 32: 254-260.

Veloso, H.P.; Rangel-Filho, A.L.R. \& Lima, J.C.A. 1991. Classificação da vegetação brasileira, adaptada a um sistema universal. Rio de Janeiro, Instituto Brasileiro de Geografia e Estatística - IBGE, 123 p.

Verdade, V.K.; Rodrigues, M.T.; Cassimiro, J.; Pavan, D.; Liou, N. \& Lange, M. 2008. Advertisement call, vocal activity, and geographic distribution of Brachycephalus hermogenesi (Giaretta and Sawaya, 1998) (Anura, Brachycephalidae). Journal of Herpetology 42: 542-549.

Walter, H. 1977. Zonas de vegetación y clima. Barcelona, Ediciones Omega, 245 p.

Wieczorek, J.; Guo, Q. \& Hijmans, R.J. 2004. The point-radius method for georeferencing locality descriptions and calculating associated uncertainty. International Journal of Geographical Information Science 18: 745-767.

Wistuba, E.M. 1998. História natural de Brachycephalus pernix Pombal, Wistuba \& Bornschein, 1998 (Anura) no Morro Anhangava, Município de Quatro Barras, Estado do Paraná. Dissertation. Curitiba, Universidade Federal do Paraná, 89 p. 
828 Wollenberg, K.C.; Vieites, D.R.; Glaw, F. \& Vences, M. 2011. Speciation in little: the role of 829 range and body size in the diversification of Malagasy mantellid frogs. BMC Evolutionary $830 \quad$ Biology 11:217.

831 Yeh, J. 2002. The effect of miniaturized body size on skeletal morphology in frogs. Evolution $83256: 628-641$.

833 Zaher, H.; Aguiar, E. \& Pombal, J.P. 2005. Paratelmatobius gaigeae (Cochran, 1938)

834 rediscovered (Amphibia, Anura, Leptodactylidae). Arquivos do Museu Nacional 63: 321835328.

836 
837 Table 1. Records of Brachycephalus spp. Altitude is provided in meters (above sea level).

\begin{tabular}{|c|c|c|c|c|c|c|}
\hline Species $^{1}$ & Relief units ${ }^{2}$ & Group $^{3}$ & Locality ${ }^{4}$ & State & Altitude & Source $^{5}$ \\
\hline B. didactylus & $\begin{array}{l}\text { Northern Serra } \\
\text { da Mantiqueira }\end{array}$ & didactylus & $\begin{array}{l}\text { Monumento Natural Serra das Torres } \\
\left(21^{\circ} 00^{\prime} 04^{\prime} \mathrm{S}, 41^{\circ} 13^{\prime} 17^{\prime} \mathrm{W}\right) \text {, } \\
\text { municipality of Atílio Vivácqua }\end{array}$ & ES & $\begin{array}{l}?(600- \\
900 ?)\end{array}$ & Oliveira et al. $(2012,2013)$ \\
\hline B. didactylus & $\begin{array}{l}\text { Northern Serra } \\
\text { do Mar }\end{array}$ & didactylus & $\begin{array}{l}\text { Fazenda Santa Bárbara }\left(22^{\circ} 25^{\prime} 17^{\prime} ’ \mathrm{~S} \text {, }\right. \\
\left.42^{\circ} 35^{\prime} 01^{\prime} \mathrm{W}\right) \text {, Parque Estadual dos } \\
\text { Três Picos, municipality of } \\
\text { Cachoeiras de Macacu }\end{array}$ & $\mathrm{RJ}$ & $\begin{array}{c}500- \\
800\end{array}$ & $\begin{array}{l}\text { Siqueira et al. (2009), Almeida- } \\
\text { Santos et al. (2011) }\end{array}$ \\
\hline B. didactylus & $\begin{array}{l}\text { Northern Serra } \\
\text { do Mar }\end{array}$ & didactylus & $\begin{array}{l}\text { Reserva Ecológica de Guapiaçu } \\
\left(22^{\circ} 24^{\prime} 00^{\prime} \mathrm{S}, 42^{\circ} 44^{\prime} 00^{\prime} \mathrm{W}\right) \\
\text { municipality of Cachoeiras de } \\
\text { Macacu }\end{array}$ & $\mathrm{RJ}$ & $\begin{array}{c}300- \\
520\end{array}$ & Siqueira et al. (2014) \\
\hline B. didactylus & $\begin{array}{l}\text { Northern Serra } \\
\text { do Mar }\end{array}$ & didactylus & $\begin{array}{l}\text { Reserva Ecológica Rio das Pedras } \\
\left(22^{\circ} 59^{\prime} 00^{\prime} \mathrm{S}, 44^{\circ} 06^{\prime} 45^{\prime} \mathrm{W}\right) \\
\text { municipality of Mangaratiba }\end{array}$ & $\mathrm{RJ}$ & $\begin{array}{l}200- \\
1,110\end{array}$ & $\begin{array}{l}\text { *, Carvalho-e-Silva et al. (2008), } \\
\text { Almeida-Santos et al. (2011), } \\
\text { Rocha et al. (2013) }\end{array}$ \\
\hline B. didactylus & $\begin{array}{l}\text { Northern Serra } \\
\text { do Mar }\end{array}$ & didactylus & $\begin{array}{l}\text { Sacra Família do Tinguá } \\
\left(22^{\circ} 29^{\prime} 11^{\prime} \mathrm{S}, 43^{\circ} 36^{\prime} 18^{\prime \prime} \mathrm{W}\right) \\
\text { municipality of Engenheiro Paulo de } \\
\text { Frontin }\end{array}$ & $\mathrm{RJ}$ & 600 & $\begin{array}{l}\text { Izecksohn (1971), Pombal (2001), } \\
\text { Ribeiro et al. (2005), Alves et al. } \\
\text { (2006, 2009), Silva et al. (2007), } \\
\text { Verdade et al. (2008), Clemente- } \\
\text { Carvalho et al. (2009), Campos } \\
\text { (2011), Pombal \& Izecksohn } \\
\text { (2011), Pie et al. (2013) }\end{array}$ \\
\hline
\end{tabular}




\begin{tabular}{|c|c|c|c|c|c|c|}
\hline Species $^{1}$ & Relief units ${ }^{2}$ & Group $^{3}$ & Locality $^{4}$ & State & Altitude & Source 5 \\
\hline B. didactylus & $\begin{array}{l}\text { Northern Serra } \\
\text { do Mar }\end{array}$ & didactylus & $\begin{array}{l}\text { Theodoro de Oliveira (first position: } \\
22^{\circ} 22^{\prime} 11^{\prime \prime} \mathrm{S}, 42^{\circ} 33^{\prime} 25^{\prime} \mathrm{W} \text { ), Parque } \\
\text { Estadual dos Três Picos, municipality } \\
\text { of Nova Friburgo }\end{array}$ & $\mathrm{RJ}$ & $\begin{array}{c}? \\
(1,100- \\
1,400 ?)\end{array}$ & *, Siqueira et al. (2011) \\
\hline B. didactylus & $\begin{array}{l}\text { Northern Serra } \\
\text { do Mar }\end{array}$ & didactylus & $\begin{array}{l}\text { Tinguá }\left(22^{\circ} 35^{\prime} 51^{\prime} \mathrm{S}, 43^{\circ} 24^{\prime} 54^{\prime \prime} \mathrm{W}\right) \text {, } \\
\text { municipality of Nova Iguaçu }\end{array}$ & $\mathrm{RJ}$ & 35 & Izecksohn (1971) \\
\hline B. didactylus & $\begin{array}{l}\text { Northern Serra } \\
\text { do Mar }\end{array}$ & didactylus & $\begin{array}{l}\text { Vila Dois Rios }\left(23^{\circ} 11^{\prime} 01^{\prime} ' \mathrm{~S},\right. \\
44^{\circ} 12^{\prime} 23^{\prime} \text { W), Ilha Grande, } \\
\text { municipality of Angra dos Reis }\end{array}$ & RJ & $\begin{array}{c}220- \\
240\end{array}$ & $\begin{array}{l}* \text {, Rocha et al. (2000, 2001), Van } \\
\text { Sluys et al. (2007) }\end{array}$ \\
\hline B. hermogenesi & $\begin{array}{l}\text { Central Serra } \\
\text { do Mar }\end{array}$ & didactylus & $\begin{array}{l}\text { Corcovado }\left(23^{\circ} 28^{\prime} 08^{\prime \prime} \mathrm{S},\right. \\
\left.45^{\circ} 11^{\prime} 29^{\prime} \mathrm{W}\right), \text { municipality of } \\
\text { Ubatuba }\end{array}$ & SP & $?(70 ?)$ & $\begin{array}{l}\text { Giaretta \& Sawaya (1998), } \\
\text { Verdade et al. (2008) }\end{array}$ \\
\hline B. hermogenesi & $\begin{array}{l}\text { Central Serra } \\
\text { do Mar }\end{array}$ & didactylus & $\begin{array}{l}\text { Estação Biológica de Boracéia (first } \\
\text { position: } 23^{\circ} 39^{\prime} 10^{\prime} \mathrm{S}, 45^{\circ} 53^{\prime} 05^{\prime} \mathrm{W} \text { ), } \\
\text { municipality of Salesópolis }\end{array}$ & SP & 900 & $\begin{array}{l}\text { Pimenta et al. (2007), Verdade et } \\
\text { al. (2008) }\end{array}$ \\
\hline B. hermogenesi & $\begin{array}{l}\text { Central Serra } \\
\text { do Mar }\end{array}$ & didactylus & $\begin{array}{l}\text { Fazenda Capricórnio }\left(23^{\circ} 23^{\prime} 27^{\prime} \mathrm{S} \text {, }\right. \\
\left.45^{\circ} 04^{\prime} 26^{\prime} \mathrm{W}\right) \text {, municipality of } \\
\text { Ubatuba }\end{array}$ & SP & 60 & $\begin{array}{l}\text { Giaretta \& Sawaya (1998), } \\
\text { Verdade et al. (2008) }\end{array}$ \\
\hline B. hermogenesi & $\begin{array}{l}\text { Central Serra } \\
\text { do Mar }\end{array}$ & didactylus & $\begin{array}{l}\text { Picinguaba }\left(23^{\circ} 22^{\prime} 21^{\prime} \text { S, }\right. \\
\left.44^{\circ} 49^{\prime} 53^{\prime} \mathrm{W}\right) \text {, Parque Estadual da } \\
\text { Serra do Mar, municipality of } \\
\text { Ubatuba }\end{array}$ & SP & $0-700$ & $\begin{array}{l}\text { Giaretta \& Sawaya (1998), } \\
\text { Pimenta et al. (2007), Verdade et } \\
\text { al. (2008), Clemente-Carvalho et } \\
\text { al. (2009), Pie et al. (2013) }\end{array}$ \\
\hline
\end{tabular}




\begin{tabular}{|c|c|c|c|c|c|c|}
\hline Species $^{1}$ & Relief units ${ }^{2}$ & Group $^{3}$ & Locality $^{4}$ & State & Altitude & Source 5 \\
\hline B. hermogenesi & $\begin{array}{l}\text { Central Serra } \\
\text { do Mar }\end{array}$ & didactylus & $\begin{array}{l}\text { Reserva Biológica do Alto da Serra } \\
\text { de Paranapiacaba }\left(23^{\circ} 46^{\prime} 40^{\prime \prime} S \text {, }\right. \\
\left.46^{\circ} 18^{\prime} 45^{\prime} \mathrm{W}\right) \text {, municipality of Santo } \\
\text { André }\end{array}$ & SP & $?(800 ?)$ & Verdade et al. (2008) \\
\hline B. hermogenesi & $\begin{array}{l}\text { Central Serra } \\
\text { do Mar }\end{array}$ & didactylus & $\begin{array}{l}\text { Reserva Florestal de Morro Grande } \\
\left(23^{\circ} 42^{\prime} 08^{\prime} \mathrm{S}, 46^{\circ} 58^{\prime} 22^{\prime} \mathrm{W}\right) \\
\text { municipality of Cotia }\end{array}$ & SP & $?(990 ?)$ & $\begin{array}{l}\text { Dixo \& Verdade (2006), Verdade } \\
\text { et al. (2008) }\end{array}$ \\
\hline B. pulex & Pré-Litorâneas & didactylus & $\begin{array}{l}\text { Serra Bonita }\left(15^{\circ} 23^{\prime} 28^{\prime \prime} \mathrm{S},\right. \\
\left.39^{\circ} 33^{\prime} 59^{\prime \prime} \mathrm{W}\right), \text { municipality of } \\
\text { Camacan }\end{array}$ & BA & $\begin{array}{c}800- \\
930\end{array}$ & Napoli et al. (2011) \\
\hline $\begin{array}{l}\text { Brachycephalus sp. } \\
1\end{array}$ & Paranapiacaba & didactylus & $\begin{array}{l}\text { Caratuval }\left(24^{\circ} 51^{\prime} 17^{\prime} \text { 'S, }\right. \\
\left.48^{\circ} 43^{\prime} 43^{\prime} \mathrm{W}\right) \text {, near the Parque } \\
\text { Estadual das Lauráceas, municipality } \\
\text { of Adrianópolis }\end{array}$ & PR & 900 & $\begin{array}{l}\text { Firkowski (2013; without species } \\
\text { identification), Pie et al. (2013; as } \\
\text { "Brachycephalus sp. nov. 1") }\end{array}$ \\
\hline $\begin{array}{l}\text { Brachycephalus sp. } \\
1\end{array}$ & Paranapiacaba & didactylus & $\begin{array}{l}\text { Caratuval }\left(24^{\circ} 51^{\prime} 14 \text { 's, }\right. \\
\left.48^{\circ} 42^{\prime} 01^{\prime} \mathrm{W}\right) \text {, Parque Estadual das } \\
\text { Lauráceas, municipality of } \\
\text { Adrianópolis }\end{array}$ & PR & 890 & $\begin{array}{l}\text { Pie et al. (2013; as } \\
\text { "Brachycephalus sp. nov. 1") }\end{array}$ \\
\hline $\begin{array}{l}\text { Brachycephalus sp. } \\
1\end{array}$ & Paranapiacaba & didactylus & $\begin{array}{l}\text { Fazenda Primavera }\left(24^{\circ} 53^{\prime} 08^{\prime} \text { 'S, }\right. \\
\left.48^{\circ} 45^{\prime} 51^{\prime} \mathrm{W}\right) \text {, municipality of Tunas } \\
\text { do Paraná }\end{array}$ & PR & 1,060 & $\begin{array}{l}\text { Pie et al. (2013; as } \\
\text { "Brachycephalus sp. nov. 1") }\end{array}$ \\
\hline $\begin{array}{l}\text { Brachycephalus sp. } \\
1\end{array}$ & Paranapiacaba & didactylus & $\begin{array}{l}\text { Fazenda Thalia }\left(25^{\circ} 30^{\prime} 58^{\prime} \mathrm{S} \text {, }\right. \\
\left.49^{\circ} 40^{\prime} 12^{\prime \prime} \mathrm{W}\right) \text {, municipality of Balsa } \\
\text { Nova }\end{array}$ & PR & 1,025 & $\begin{array}{l}\text { Firkowski (2013; without species } \\
\text { identification), Pie et al. (2013; as } \\
\text { "Brachycephalus sp. nov. 1") }\end{array}$ \\
\hline
\end{tabular}




\begin{tabular}{|c|c|c|c|c|c|c|}
\hline Species $^{1}$ & Relief units $^{2}$ & Group $^{3}$ & Locality ${ }^{4}$ & State & Altitude & Source $^{5}$ \\
\hline $\begin{array}{l}\text { Brachycephalus sp. } \\
1\end{array}$ & Paranapiacaba & didactylus & $\begin{array}{l}\text { Base of the Serra Água Limpa } \\
\left(24^{\circ} 28^{\prime} 52^{\prime} \mathrm{S}, 48^{\circ} 47^{\prime} 12^{\prime \prime} \mathrm{W}\right) \\
\text { municipality of Apiaí }\end{array}$ & SP & 920 & $\begin{array}{l}*, \text { DZUP, Firkowski (2013; } \\
\text { without species identification) }\end{array}$ \\
\hline $\begin{array}{l}\text { Brachycephalus sp. } \\
1\end{array}$ & $\begin{array}{l}\text { Southern Serra } \\
\text { do Mar }\end{array}$ & didactylus & $\begin{array}{l}\text { Alto Quiriri }\left(26^{\circ} 05^{\prime} 34^{\prime \prime} \mathrm{S} \text {, }\right. \\
\left.48^{\circ} 59^{\prime} 41^{\prime \prime} \mathrm{W}\right) \text {, municipality of Garuva }\end{array}$ & $\mathrm{SC}$ & 240 & $\begin{array}{l}\text { Pie et al. (2013; as } \\
\text { "Brachycephalus sp. nov. 1") }\end{array}$ \\
\hline $\begin{array}{l}\text { Brachycephalus sp. } \\
1\end{array}$ & $\begin{array}{l}\text { Southern Serra } \\
\text { do Mar }\end{array}$ & didactylus & $\begin{array}{l}\text { Castelo dos Bugres (first position: } \\
26^{\circ} 13^{\prime} 47^{\prime \prime} \mathrm{S}, 49^{\circ} 03^{\prime} 20^{\prime \prime} \mathrm{W} \text { ), } \\
\text { municipality of Joinville }\end{array}$ & $\mathrm{SC}$ & $\begin{array}{c}790- \\
860\end{array}$ & $\begin{array}{l}\text { Pie et al. (2013; as } \\
\text { "Brachycephalus sp. nov. 1") }\end{array}$ \\
\hline $\begin{array}{l}\text { Brachycephalus sp. } \\
1\end{array}$ & $\begin{array}{l}\text { Southern Serra } \\
\text { do Mar }\end{array}$ & didactylus & $\begin{array}{l}\text { Colônia Castelhanos }\left(25^{\circ} 47^{\prime} 58^{\prime} \mathrm{S} \text {, }\right. \\
\left.48^{\circ} 54^{\prime} 40^{\prime} \mathrm{W}\right) \text {, municipality of } \\
\text { Guaratuba }\end{array}$ & PR & 290 & $\begin{array}{l}\text { Cunha et al. (2010; as } \\
\text { "Brachycephalus aff. } \\
\text { hermogenesi"), Oliveira et al. } \\
\text { ( } 2011 \text {; as "B. hermogenesi"), Pie } \\
\text { et al. (2013; as "Brachycephalus } \\
\text { sp. nov. 1") }\end{array}$ \\
\hline $\begin{array}{l}\text { Brachycephalus sp. } \\
1\end{array}$ & $\begin{array}{l}\text { Southern Serra } \\
\text { do Mar }\end{array}$ & didactylus & $\begin{array}{l}\text { Corvo }\left(25^{\circ} 20^{\prime} 17^{\prime \prime} \mathrm{S}, 48^{\circ} 54^{\prime} 56^{\prime \prime} \mathrm{W}\right) \text {, } \\
\text { municipality of Quatro Barras }\end{array}$ & PR & 930 & $\begin{array}{l}\text { Firkowski (2013; without species } \\
\text { identification), Pie et al. (2013; as } \\
\text { "Brachycephalus sp. nov. 1") }\end{array}$ \\
\hline $\begin{array}{l}\text { Brachycephalus sp. } \\
1\end{array}$ & $\begin{array}{l}\text { Southern Serra } \\
\text { do Mar }\end{array}$ & didactylus & $\begin{array}{l}\text { Dona Francisca }\left(26^{\circ} 09^{\prime} 52^{\prime} ’ \mathrm{~S} \text {, }\right. \\
\left.48^{\circ} 59^{\prime} 23 ” \mathrm{~W}\right) \text {, municipality of } \\
\text { Joinville }\end{array}$ & $\mathrm{SC}$ & 150 & $\begin{array}{l}\text { Pie et al. (2013; as } \\
\text { "Brachycephalus sp. nov. 1") }\end{array}$ \\
\hline $\begin{array}{l}\text { Brachycephalus sp. } \\
1\end{array}$ & $\begin{array}{l}\text { Southern Serra } \\
\text { do Mar }\end{array}$ & didactylus & $\begin{array}{l}\text { Estrada do rio do Júlio }\left(26^{\circ} 17^{\prime} 02^{\prime} ’ \mathrm{~S},\right. \\
\left.49^{\circ} 06^{\prime} 08^{\prime} \mathrm{W}\right) \text {, municipality of } \\
\text { Joinville }\end{array}$ & $\mathrm{SC}$ & 650 & $\begin{array}{l}\text { Mariotto (2014; as } \\
\text { "Brachycephalus sp.") }\end{array}$ \\
\hline
\end{tabular}




\begin{tabular}{|c|c|c|c|c|c|c|}
\hline Species $^{1}$ & Relief units ${ }^{2}$ & Group $^{3}$ & Locality ${ }^{4}$ & State & Altitude & Source $^{5}$ \\
\hline $\begin{array}{l}\text { Brachycephalus sp. } \\
1\end{array}$ & $\begin{array}{l}\text { Southern Serra } \\
\text { do Mar }\end{array}$ & didactylus & $\begin{array}{l}\text { Fazenda Pico Paraná }\left(25^{\circ} 13^{\prime} 29^{\prime} ’ \mathrm{~S},\right. \\
\left.48^{\circ} 51^{\prime} 17^{\prime} \mathrm{W}\right) \text {, municipality of } \\
\text { Campina Grande do Sul }\end{array}$ & PR & 1,050 & $\begin{array}{l}\text { Pie et al. (2013; as } \\
\text { "Brachycephalus sp. nov. 1") }\end{array}$ \\
\hline $\begin{array}{l}\text { Brachycephalus sp. } \\
1\end{array}$ & $\begin{array}{l}\text { Southern Serra } \\
\text { do Mar }\end{array}$ & didactylus & $\begin{array}{l}\text { Mananciais da Serra }\left(25^{\circ} 29^{\prime} 29^{\prime} \mathrm{S} \text {, }\right. \\
\left.48^{\circ} 58^{\prime} 40^{\prime} \mathrm{W}\right) \text {, municipality of } \\
\text { Piraquara }\end{array}$ & PR & 1,050 & $\begin{array}{l}\text { *, DZUP, Pie et al. (2013; as } \\
\text { “Brachycephalus sp. nov. 1”) }\end{array}$ \\
\hline $\begin{array}{l}\text { Brachycephalus sp. } \\
1\end{array}$ & $\begin{array}{l}\text { Southern Serra } \\
\text { do Mar }\end{array}$ & didactylus & $\begin{array}{l}\text { Pico Agudinho }\left(25^{\circ} 36^{\prime} 24^{\prime} \mathrm{S} \text {, }\right. \\
\left.48^{\circ} 43^{\prime} 33^{\prime} \mathrm{W}\right) \text {, Serra da Prata, } \\
\text { municipality of Morretes }\end{array}$ & PR & 385 & $\begin{array}{l}\text { Pie et al. (2013; as } \\
\text { "Brachycephalus sp. nov. 1") }\end{array}$ \\
\hline $\begin{array}{l}\text { Brachycephalus sp. } \\
1\end{array}$ & $\begin{array}{l}\text { Southern Serra } \\
\text { do Mar }\end{array}$ & didactylus & $\begin{array}{l}\text { Recanto das Hortências }\left(25^{\circ} 33^{\prime} 24^{\prime \prime S} \text {, }\right. \\
\left.48^{\circ} 59^{\prime} 38^{\prime \prime W}\right) \text {, municipality of São } \\
\text { José dos Pinhais }\end{array}$ & PR & 975 & *, DZUP \\
\hline $\begin{array}{l}\text { Brachycephalus sp. } \\
1\end{array}$ & $\begin{array}{l}\text { Southern Serra } \\
\text { do Mar }\end{array}$ & didactylus & $\begin{array}{l}\text { Reserva Particular do Patrimônio } \\
\text { Natural Salto Morato }\left(25^{\circ} 10^{\prime} 00^{\prime} \text {, }\right. \\
48^{\circ} 17 ’ 21 \text { 'W), municipality of } \\
\text { Guaraqueçaba }\end{array}$ & PR & $45-900$ & $\begin{array}{l}\text { *, Pereira et al. (2010; as “ } B \text {. } \\
\text { hermogenesi"), Santos-Pereira et } \\
\text { al. (2011; as “B. hermogenesi”) }\end{array}$ \\
\hline $\begin{array}{l}\text { Brachycephalus sp. } \\
1\end{array}$ & $\begin{array}{l}\text { Southern Serra } \\
\text { do Mar }\end{array}$ & didactylus & $\begin{array}{l}\text { Sítio Ananias }\left(25^{\circ} 47^{\prime} 08^{\prime} \mathrm{S} \text {, }\right. \\
\left.48^{\circ} 43^{\prime} 03^{\prime} \mathrm{W}\right) \text {, municipality of } \\
\text { Guaratuba }\end{array}$ & PR & 25 & $\begin{array}{l}\text { Pie et al. (2013; as } \\
\text { "Brachycephalus sp. nov. 1") }\end{array}$ \\
\hline $\begin{array}{l}\text { Brachycephalus sp. } \\
1\end{array}$ & $\begin{array}{l}\text { Southern Serra } \\
\text { do Mar }\end{array}$ & didactylus & $\begin{array}{l}\text { Truticultura }\left(26^{\circ} 01^{\prime} 33^{\prime} " \mathrm{~S},\right. \\
\left.48^{\circ} 52^{\prime} 02^{\prime} \mathrm{W}\right) \text {, municipality of Garuva }\end{array}$ & $\mathrm{SC}$ & 90 & $\begin{array}{l}\text { Pie et al. (2013; as } \\
\text { "Brachycephalus sp. nov. 1") }\end{array}$ \\
\hline
\end{tabular}




\begin{tabular}{|c|c|c|c|c|c|c|}
\hline Species $^{1}$ & Relief units ${ }^{2}$ & Group $^{3}$ & Locality $^{4}$ & State & Altitude & Source 5 \\
\hline B. alipioi & $\begin{array}{l}\text { Northern Serra } \\
\text { da Mantiqueira }\end{array}$ & ephippium & $\begin{array}{l}\text { Fazenda Aoki or Fazenda dos } \\
\text { Japoneses }\left(20^{\circ} 28^{\prime} 24^{\prime} \mathrm{S}, 41^{\circ} 00^{\prime} 36^{\prime \prime}\right. \\
\text { W), boundary of the municipalities of } \\
\text { Vargem Alta and Domingos Martins }\end{array}$ & ES & $\begin{array}{c}1,070- \\
1,100\end{array}$ & $\begin{array}{l}\text { Pombal \& Gasparini (2006), } \\
\text { Clemente-Carvalho et al. (2009, } \\
\text { 2011a, 2012), Pombal \& } \\
\text { Izecksohn (2011), Pie et al. } \\
\text { (2013) }\end{array}$ \\
\hline B. alipioi & $\begin{array}{l}\text { Northern Serra } \\
\text { da Mantiqueira }\end{array}$ & ephippium & $\begin{array}{l}\text { Forno Grande }\left(20^{\circ} 31^{\prime} 41^{\prime} ’ \mathrm{~S},\right. \\
\left.41^{\circ} 06{ }^{\prime} 51^{\prime} \mathrm{W}\right) \text {, Parque Estadual de } \\
\text { Forno Grande, municipality of } \\
\text { Castelo }\end{array}$ & ES & $\begin{array}{c}? \\
(1,430 ?)\end{array}$ & Pie et al. (2013) \\
\hline B. bufonoides & $\begin{array}{l}\text { Northern Serra } \\
\text { do Mar }\end{array}$ & ephippium & $\begin{array}{l}\text { Serra de Macaé }\left(22^{\circ} 18^{\prime} 02^{\prime} \mathrm{S},\right. \\
\left.42^{\circ} 18^{\prime} 20^{\prime} \mathrm{W}\right) \text {, municipality of Nova } \\
\text { Friburgo }\end{array}$ & $\mathrm{RJ}$ & $\begin{array}{c}? \\
(1,100 ?)\end{array}$ & $\begin{array}{l}\text { Miranda-Ribeiro (1920), Pombal } \\
\text { (2010), Pombal \& Izecksohn } \\
\text { (2011) }\end{array}$ \\
\hline B. crispus & $\begin{array}{l}\text { Central Serra } \\
\text { do Mar }\end{array}$ & ephippium & $\begin{array}{l}\text { Bacia B, Núcleo Cunha, Parque } \\
\text { Estadual da Serra do Mar } \\
\left(23^{\circ} 15^{\prime} 15^{\prime} \mathrm{S}, 45^{\circ} 01^{\prime} 58^{\prime} \mathrm{W}\right) \\
\text { municipality of Cunha }\end{array}$ & SP & $\begin{array}{l}800- \\
1,100\end{array}$ & Condez et al. (2014) \\
\hline B. ephippium & $\begin{array}{l}\text { Northern Serra } \\
\text { da Mantiqueira }\end{array}$ & ephippium & $\begin{array}{l}\text { Serra do Pai Inácio }\left(20^{\circ} 48^{\prime} 13^{\prime} \text { 'S, }\right. \\
42^{\circ} 29^{\prime} 07^{\prime} \text { W), Parque Estadual da } \\
\text { Serra do Brigadeiro, boundary of the } \\
\text { municipalities of Ervália and } \\
\text { Miradouro }\end{array}$ & MG & $\begin{array}{c}? \\
(1,350 ?)\end{array}$ & Pombal \& Izecksohn (2011) \\
\hline B. ephippium & $\begin{array}{l}\text { Southern Serra } \\
\text { da Mantiqueira }\end{array}$ & ephippium & $\begin{array}{l}\text { Condomínio Ermida }\left(23^{\circ} 14{ }^{\prime} 13^{\prime} \mathrm{S} \text {, }\right. \\
\left.46^{\circ} 58^{\prime} 52^{\prime} \mathrm{W}\right) \text {, Serra do Japi, } \\
\text { municipality of Jundiaí }\end{array}$ & SP & 1,225 & Pie et al. (2013) \\
\hline
\end{tabular}




\begin{tabular}{|c|c|c|c|c|c|c|}
\hline Species $^{1}$ & Relief units ${ }^{2}$ & Group $^{3}$ & Locality $^{4}$ & State & Altitude & Source ${ }^{5}$ \\
\hline B. ephippium & $\begin{array}{l}\text { Southern Serra } \\
\text { da Mantiqueira }\end{array}$ & ephippium & $\begin{array}{l}\text { Hotel Fazenda Pé da Serra } \\
\left(22^{\circ} 51^{\prime} 56^{\prime} \mathrm{S}, 45^{\circ} 31^{\prime} 40^{\prime} \mathrm{W}\right), \\
\text { municipality of Pindamonhangaba }\end{array}$ & SP & 700 & Pie et al. (2013) \\
\hline B. ephippium & $\begin{array}{l}\text { Southern Serra } \\
\text { da Mantiqueira }\end{array}$ & ephippium & $\begin{array}{l}\text { Lago Azul }\left(22^{\circ} 27^{\prime} 23 ’ \mathrm{~S},\right. \\
\left.44^{\circ} 36 ’ 34^{\prime} \mathrm{W}\right) \text {, Parque Nacional do } \\
\text { Itatiaia, municipality of Itatiaia }\end{array}$ & $\mathrm{RJ}$ & 750 & Pie et al. (2013) \\
\hline B. ephippium & $\begin{array}{l}\text { Southern Serra } \\
\text { da Mantiqueira }\end{array}$ & ephippium & $\begin{array}{l}\text { Maromba }\left(22^{\circ} 25^{\prime} 43^{\prime} \mathrm{S},\right. \\
\left.44^{\circ} 37^{\prime} 11^{\prime \prime} \mathrm{W}\right) \text {, Parque Nacional do } \\
\text { Itatiaia, municipality of Itatiaia }\end{array}$ & RJ & 1,125 & Pie et al. (2013) \\
\hline B. ephippium & $\begin{array}{l}\text { Southern Serra } \\
\text { da Mantiqueira }\end{array}$ & ephippium & $\begin{array}{l}\text { Monteiro Lobato }\left(22^{\circ} 57^{\prime} 07^{\prime} ’ \mathrm{~S},\right. \\
\left.45^{\circ} 50^{\prime} 20^{\prime} \mathrm{W}\right) \text {, municipality of } \\
\text { Monteiro Lobato }\end{array}$ & SP & 700 & Pombal \& Izecksohn (2011) \\
\hline B. ephippium & $\begin{array}{l}\text { Southern Serra } \\
\text { da Mantiqueira }\end{array}$ & ephippium & $\begin{array}{l}\text { Observatório de Capricórnio } \\
\left(22^{\circ} 53 \text { '54'S, } 46^{\circ} 49^{\prime} 01 \text { '” }\right) \text {, Serra das } \\
\text { Cabras, Joaquim Egídio District, } \\
\text { boundary of the municipalities of } \\
\text { Campinas and Morungaba }\end{array}$ & SP & 1,085 & $\begin{array}{l}\text { Pombal (1999), Pombal et al. } \\
\text { (1994), Pombal \& Izecksohn } \\
\text { (2011), Pie et al. (2013) }\end{array}$ \\
\hline B. ephippium & $\begin{array}{l}\text { Southern Serra } \\
\text { da Mantiqueira }\end{array}$ & ephippium & $\begin{array}{l}\text { Parque Municipal de Itapetinga } \\
\text { (Grota Funda) }\left(23^{\circ} 11^{\prime} 07^{\prime} \mathrm{S} \text {, }\right. \\
\left.46^{\circ} 31^{\prime} 47^{\prime} \mathrm{W}\right) \text {, municipality of Atibaia }\end{array}$ & SP & $\begin{array}{l}900- \\
1,250\end{array}$ & $\begin{array}{l}\text { Giaretta (1999), Giaretta et al. } \\
\text { (1999), Clemente-Carvalho et al. } \\
(2009,2011 \text { a), Pie et al. (2013) }\end{array}$ \\
\hline B. ephippium & $\begin{array}{l}\text { Southern Serra } \\
\text { da Mantiqueira }\end{array}$ & ephippium & $\begin{array}{l}\text { Reserva Biológica da Serra do Japi } \\
\left(23^{\circ} 17^{\prime} 07^{\prime} \text { 'S } 47^{\circ} 00^{\prime} 05^{\prime} \mathrm{W}\right) \text {, Serra do } \\
\text { Japi, boundary of the municipalities } \\
\text { of Jundiaí and Cabreúva }\end{array}$ & SP & 1,000 & $\begin{array}{l}\text { Giaretta et al. (1997), Pombal \& } \\
\text { Izecksohn (2011), Clemente- } \\
\text { Carvalho et al. (2009, 2016), Pie } \\
\text { et al. (2013) }\end{array}$ \\
\hline
\end{tabular}




\begin{tabular}{|c|c|c|c|c|c|c|}
\hline Species $^{1}$ & Relief units ${ }^{2}$ & Group $^{3}$ & Locality $^{4}$ & State & Altitude & Source ${ }^{5}$ \\
\hline B. ephippium & $\begin{array}{l}\text { Southern Serra } \\
\text { da Mantiqueira }\end{array}$ & ephippium & $\begin{array}{l}\text { Reserva Ecológica do Trabiju } \\
\left(22^{\circ} 48^{\prime} 01^{\prime} \text { S }, 45^{\circ} 32^{\prime} 03^{\prime} \mathrm{W}\right) \text {, Trabiju, } \\
\text { municipality of Pindamonhangaba }\end{array}$ & SP & $\begin{array}{c}? \\
(1,000 ?)\end{array}$ & Pombal \& Izecksohn (2011) \\
\hline B. ephippium & $\begin{array}{l}\text { Southern Serra } \\
\text { da Mantiqueira }\end{array}$ & ephippium & $\begin{array}{l}\text { Reserva Pedra Branca }\left(22^{\circ} 56^{\prime} 22^{\prime} \mathrm{S} \text {, }\right. \\
\left.45^{\circ} 41^{\prime} 04^{\prime \prime} \mathrm{W}\right) \text {, municipality of } \\
\text { Tremembé }\end{array}$ & SP & $?(890 ?)$ & Pombal \& Izecksohn (2011) \\
\hline B. ephippium & $\begin{array}{l}\text { Southern Serra } \\
\text { da Mantiqueira }\end{array}$ & ephippium & $\begin{array}{l}\text { Santo Antônio do Pinhal } \\
\left(22^{\circ} 49^{\prime} 28^{\prime} \mathrm{S}, 45^{\circ} 40^{\prime} 20^{\prime} \mathrm{W}\right) \text {, } \\
\text { municipality of Santo Antônio do } \\
\text { Pinhal }\end{array}$ & SP & 1,080 & Pombal \& Izecksohn (2011) \\
\hline B. ephippium & $\begin{array}{l}\text { Southern Serra } \\
\text { da Mantiqueira }\end{array}$ & ephippium & $\begin{array}{l}\text { São Francisco Xavier }\left(22^{\circ} 53^{\prime} 44^{\prime} \text { S, }\right. \\
45^{\circ} 58^{\prime} 04^{\prime} \text { 'W), municipality of São } \\
\text { José dos Campos }\end{array}$ & SP & 1,000 & $\begin{array}{l}\text { Clemente-Carvalho et al. (2008, } \\
\text { 2011b, 2016), Pombal \& } \\
\text { Izecksohn (2011), Pie et al. } \\
\text { (2013) }\end{array}$ \\
\hline B. ephippium & $\begin{array}{l}\text { Southern Serra } \\
\text { da Mantiqueira }\end{array}$ & ephippium & $\begin{array}{l}\text { Serra Negra }\left(21^{\circ} 57^{\prime} 28^{\prime} \text { S, }\right. \\
\left.43^{\circ} 47^{\prime} 20^{\prime \prime}\right) \text {, municipality of Santa } \\
\text { Bárbara do Monte Verde }\end{array}$ & MG & $?$ & Campos (2011; as “BMV MG2”) \\
\hline B. ephippium & Paraíba do Sul & ephippium & $\begin{array}{l}\text { Serra da Concórdia }\left(22^{\circ} 20^{\prime} 30^{\prime} \text { S, }\right. \\
\left.43^{\circ} 44^{\prime} 04^{\prime \prime W}\right) \text {, Parque Estadual Serra } \\
\text { da Concórdia, Barão de Juparanã, } \\
\text { municipality of Valença }\end{array}$ & RJ & $?(900 ?)$ & Pombal \& Izecksohn (2011) \\
\hline B. ephippium & $\begin{array}{l}\text { Northern Serra } \\
\text { do Mar }\end{array}$ & ephippium & $\begin{array}{l}\text { Alto do Soberbo }\left(22^{\circ} 27^{\prime} 15^{\prime} \mathrm{S} \text {, }\right. \\
\left.42^{\circ} 59^{\prime} 21^{\prime \prime} \mathrm{W}\right) \text {, municipality of } \\
\text { Teresópolis }\end{array}$ & $\mathrm{RJ}$ & 1,250 & Pombal \& Izecksohn (2011) \\
\hline
\end{tabular}




\begin{tabular}{|c|c|c|c|c|c|c|}
\hline Species $^{1}$ & Relief units ${ }^{2}$ & Group $^{3}$ & Locality $^{4}$ & State & Altitude & Source 5 \\
\hline B. ephippium & $\begin{array}{l}\text { Northern Serra } \\
\text { do Mar }\end{array}$ & ephippium & $\begin{array}{l}\text { Comary }\left(22^{\circ} 27^{\prime} 22^{\prime} \mathrm{S}, 42^{\circ} 58^{\prime} 24^{\prime \prime} \mathrm{W}\right) \\
\text { municipality of Teresópolis }\end{array}$ & $\mathrm{RJ}$ & 990 & Pombal \& Izecksohn (2011) \\
\hline B. ephippium & $\begin{array}{l}\text { Northern Serra } \\
\text { do Mar }\end{array}$ & ephippium & $\begin{array}{l}\text { Floresta dos Macacos }\left(22^{\circ} 58^{\prime} 15^{\prime \prime} \mathrm{S} \text {, }\right. \\
\left.43^{\circ} 15^{\prime} 24^{\prime \prime} \mathrm{W}\right) \text {, municipality of Rio de } \\
\text { Janeiro }\end{array}$ & RJ & $?(450 ?)$ & Pombal \& Izecksohn (2011) \\
\hline B. ephippium & $\begin{array}{l}\text { Northern Serra } \\
\text { do Mar }\end{array}$ & ephippium & $\begin{array}{l}\text { Garrafão }\left(22^{\circ} 28^{\prime} 04^{\prime \prime} \mathrm{S}, 43^{\circ} 01^{\prime} 52^{\prime \prime} \mathrm{W}\right) \text {, } \\
\text { municipality of Guapimirim }\end{array}$ & $\mathrm{RJ}$ & $\begin{array}{c}? \\
(1,785 ?)\end{array}$ & Pombal \& Izecksohn (2011) \\
\hline B. ephippium & $\begin{array}{l}\text { Northern Serra } \\
\text { do Mar }\end{array}$ & ephippium & $\begin{array}{l}\text { Pedra Branca }\left(22^{\circ} 55^{\prime} 55^{\prime} \mathrm{S} \text {, }\right. \\
\left.43^{\circ} 28^{\prime} 23^{\prime} \mathrm{W}\right) \text {, Serra da Pedra Branca, } \\
\text { municipality of Rio de Janeiro }\end{array}$ & RJ & 1,000 & $\begin{array}{l}\text { Pombal (2001), Pombal \& } \\
\text { Izecksohn (2011) }\end{array}$ \\
\hline B. ephippium & $\begin{array}{l}\text { Northern Serra } \\
\text { do Mar }\end{array}$ & ephippium & $\begin{array}{l}\text { Represa do Rio Grande }\left(22^{\circ} 55^{\prime} 58^{\prime} \text { 'S, }\right. \\
\left.43^{\circ} 26^{\prime} 36^{\prime} \mathrm{W}\right) \text {, Parque Estadual da } \\
\text { Pedra Branca, municipality of Rio de } \\
\text { Janeiro }\end{array}$ & $\mathrm{RJ}$ & $?(150 ?)$ & $\begin{array}{l}\text { Pombal \& Izecksohn (2011), Pie } \\
\text { et al. (2013) }\end{array}$ \\
\hline B. ephippium & $\begin{array}{l}\text { Northern Serra } \\
\text { do Mar }\end{array}$ & ephippium & $\begin{array}{l}\text { Reserva Ecológica Rio das Pedras } \\
\left(22^{\circ} 59^{\prime} 00^{\prime} \mathrm{S}, 44^{\circ} 06^{\prime} 45^{\prime} \mathrm{W}\right) \\
\text { municipality of Mangaratiba }\end{array}$ & RJ & $\begin{array}{l}200- \\
1,110\end{array}$ & Carvalho-e-Silva et al. (2008) \\
\hline B. ephippium & $\begin{array}{l}\text { Northern Serra } \\
\text { do Mar }\end{array}$ & ephippium & $\begin{array}{l}\text { Riacho Beija-flor }\left(22^{\circ} 27^{\prime} 04^{\prime} \text { 'S, }\right. \\
43^{\circ} 00^{\prime} 04^{\prime \prime} \text { 'W, Parque Nacional da } \\
\text { Serra dos Órgãos, municipality of } \\
\text { Teresópolis }\end{array}$ & $\mathrm{RJ}$ & 1,195 & Pie et al. (2013) \\
\hline
\end{tabular}




\begin{tabular}{|c|c|c|c|c|c|c|}
\hline Species $^{1}$ & Relief units ${ }^{2}$ & Group $^{3}$ & Locality $^{4}$ & State & Altitude & Source 5 \\
\hline B. ephippium & $\begin{array}{l}\text { Northern Serra } \\
\text { do Mar }\end{array}$ & ephippium & $\begin{array}{l}\text { Rocio District }\left(22^{\circ} 28^{\prime} 23^{\prime \prime} \mathrm{S},\right. \\
\left.43^{\circ} 14^{\prime} 38^{\prime \prime} \mathrm{W}\right) \text {, municipality of } \\
\text { Petrópolis }\end{array}$ & RJ & 950 & Pie et al. (2013) \\
\hline B. ephippium & $\begin{array}{l}\text { Northern Serra } \\
\text { do Mar }\end{array}$ & ephippium & $\begin{array}{l}\text { Serra do Tinguá }\left(22^{\circ} 35^{\prime} 31^{\prime \prime} \mathrm{S},\right. \\
\left.43^{\circ} 28^{\prime} 16^{\prime} \mathrm{W}\right) \text {, municipality of Nova } \\
\text { Iguaçu }\end{array}$ & $\mathrm{RJ}$ & $?(950 ?)$ & Pombal \& Izecksohn (2011) \\
\hline B. ephippium & $\begin{array}{l}\text { Northern Serra } \\
\text { do Mar }\end{array}$ & ephippium & $\begin{array}{l}\text { Vale da Revolta }\left(22^{\circ} 26^{\prime} 17^{\prime \prime} \mathrm{S} \text {, }\right. \\
\left.42^{\circ} 56^{\prime} 19^{\prime \prime} \mathrm{W}\right) \text {, municipality of } \\
\text { Teresópolis }\end{array}$ & $\mathrm{RJ}$ & 1,035 & Pombal \& Izecksohn (2011) \\
\hline B. ephippium & $\begin{array}{l}\text { Northern Serra } \\
\text { do Mar }\end{array}$ & ephippium & $\begin{array}{l}\text { Varginha }\left(22^{\circ} 24^{\prime} 34^{\prime} ’ \mathrm{~S}, 42^{\circ} 52^{\prime} 11^{\prime \prime} \mathrm{W}\right) \text {, } \\
\text { municipality of Teresópolis }\end{array}$ & $\mathrm{RJ}$ & $?(825 ?)$ & Pombal \& Izecksohn (2011) \\
\hline B. ephippium & $\begin{array}{l}\text { Central Serra } \\
\text { do Mar }\end{array}$ & ephippium & $\begin{array}{l}\text { Bonito }\left(22^{\circ} 42^{\prime} 51^{\prime \prime} \mathrm{S}, 44^{\circ} 34^{\prime} 39^{\prime \prime} \mathrm{W}\right) \text {, } \\
\text { Serra da Bocaina, municipality of São } \\
\text { José do Barreiro }\end{array}$ & SP & $\begin{array}{c}? \\
(1,660 ?)\end{array}$ & Pombal \& Izecksohn (2011) \\
\hline B. ephippium & $\begin{array}{l}\text { Central Serra } \\
\text { do Mar }\end{array}$ & ephippium & $\begin{array}{l}\text { Estação Ecológica de Bananal } \\
\left(22^{\circ} 48^{\prime} 05^{\prime} \text { 'S } 44^{\circ} 22^{\prime} 12^{\prime} \mathrm{W}\right) \text {, Serra da } \\
\text { Bocaina, municipality of Bananal }\end{array}$ & SP & $\begin{array}{c}? \\
(1,200 ?)\end{array}$ & Zaher et al. (2005) \\
\hline B. ephippium & $\begin{array}{l}\text { Central Serra } \\
\text { do Mar }\end{array}$ & ephippium & $\begin{array}{l}\text { Lídice District }\left(22^{\circ} 500^{\prime} 01^{\prime} \mathrm{S} \text {, }\right. \\
\left.44^{\circ} 11^{\prime} 32^{\prime} \mathrm{W}\right), \text { municipality of Rio } \\
\text { Claro }\end{array}$ & $\mathrm{RJ}$ & $?(650 ?)$ & $\begin{array}{l}\text { Pombal (2001), Pombal \& } \\
\text { Izecksohn (2011) }\end{array}$ \\
\hline B. ephippium & $\begin{array}{l}\text { Central Serra } \\
\text { do Mar }\end{array}$ & ephippium & $\begin{array}{l}\text { Pedra Branca }\left(23^{\circ} 10^{\prime} 38^{\prime \prime} \mathrm{S},\right. \\
\left.44^{\circ} 47^{\prime} 19^{\prime \prime} \mathrm{W}\right) \text {, Serra da Bocaina, } \\
\text { municipality of Parati }\end{array}$ & RJ & $?(630 ?)$ & $\begin{array}{l}\text { Pombal (2001), Pombal \& } \\
\text { Izecksohn (2011) }\end{array}$ \\
\hline
\end{tabular}




\begin{tabular}{|c|c|c|c|c|c|c|}
\hline Species $^{1}$ & Relief units ${ }^{2}$ & Group $^{3}$ & Locality $^{4}$ & State & Altitude & Source 5 \\
\hline B. ephippium & $\begin{array}{l}\text { Central Serra } \\
\text { do Mar }\end{array}$ & ephippium & $\begin{array}{l}\text { Penísula do Bororé }\left(23^{\circ} 47^{\prime} 11^{\prime \prime S} \text {, }\right. \\
\left.46^{\circ} 38^{\prime} 45^{\prime} \mathrm{W}\right) \text {, Represa Billings, } \\
\text { Grajaú District, municipality of São } \\
\text { Paulo }\end{array}$ & SP & 780 & $\begin{array}{l}\text { Pie et al. (2013; as } \\
\text { "Brachycephalus nodoterga"), } \\
\text { Abbeg et al. (2015; as "clearly } \\
\text { refers to another species [than } B \text {. } \\
\text { nodoterga of Pie et al. 2013]") }\end{array}$ \\
\hline B. ephippium & $\begin{array}{l}\text { Central Serra } \\
\text { do Mar }\end{array}$ & ephippium & $\begin{array}{l}\text { Reserva Florestal de Morro Grande } \\
\left(23^{\circ} 42^{\prime} 08^{\prime} \mathrm{S}, 46^{\circ} 58^{\prime} 22^{\prime} \mathrm{W}\right) \\
\text { municipality of Cotia }\end{array}$ & SP & $?(990 ?)$ & Dixo \& Verdade (2006) \\
\hline B. garbeanus & $\begin{array}{l}\text { Northern Serra } \\
\text { do Mar }\end{array}$ & ephippium & $\begin{array}{l}\text { Alto Caledônia }\left(22^{\circ} 20^{\prime} 10^{\prime} \mathrm{S},\right. \\
\left.42^{\circ} 33^{\prime} 20^{\prime} \mathrm{W}\right), \text { municipality of Nova } \\
\text { Friburgo }\end{array}$ & $\mathrm{RJ}$ & $\begin{array}{c}? \\
(1,070 ?)\end{array}$ & Pombal \& Izecksohn (2011) \\
\hline B. garbeanus & $\begin{array}{l}\text { Northern Serra } \\
\text { do Mar }\end{array}$ & ephippium & $\begin{array}{l}\text { Baixo Caledônia }\left(22^{\circ} 21^{\prime} 33^{\prime} \text { S, }\right. \\
\left.42^{\circ} 34^{\prime} 12^{\prime} \mathrm{W}\right) \text {, municipality of Nova } \\
\text { Friburgo }\end{array}$ & $\mathrm{RJ}$ & $\begin{array}{l}1,600- \\
1,900\end{array}$ & $\begin{array}{l}\text { Pombal \& Izecksohn (2011); } \\
\text { Siqueira et al. (2011, 2013), } \\
\text { Dorigo et al. (2012) }\end{array}$ \\
\hline B. garbeanus & $\begin{array}{l}\text { Northern Serra } \\
\text { do Mar }\end{array}$ & ephippium & $\begin{array}{l}\text { Macaé de Cima }\left(22^{\circ} 21^{\prime} 37^{\prime} \mathrm{S},\right. \\
\left.42^{\circ} 17^{\prime} 50^{\prime \prime} \mathrm{W}\right) \text {, municipality of Nova } \\
\text { Friburgo }\end{array}$ & $\mathrm{RJ}$ & 1,130 & $\begin{array}{l}\text { Clemente-Carvalho et al. ( } 2008 \\
\text { [as “B. ephippium"], } 2009 \text { [as “ } B \text {. } \\
\text { ephippium"], 2011a,b [“b”, as " } B \text {. } \\
\text { ephippium"]), Pombal \& } \\
\text { Izecksohn (2011), Pie et al. } \\
\text { (2013) }\end{array}$ \\
\hline B. garbeanus & $\begin{array}{l}\text { Northern Serra } \\
\text { do Mar }\end{array}$ & ephippium & $\begin{array}{l}\text { Morro São João }\left(22^{\circ} 22^{\prime} 47^{\prime} \text { S, }\right. \\
\left.42^{\circ} 30^{\prime} 34^{\prime \prime} \mathrm{W}\right) \text {, municipality of Nova } \\
\text { Friburgo }\end{array}$ & $\mathrm{RJ}$ & $\begin{array}{c}? \\
(1,550 ?)\end{array}$ & Pombal \& Izecksohn (2011) \\
\hline
\end{tabular}




\begin{tabular}{|c|c|c|c|c|c|c|}
\hline Species $^{1}$ & Relief units ${ }^{2}$ & Group $^{3}$ & Locality $^{4}$ & State & Altitude & Source 5 \\
\hline B. garbeanus & $\begin{array}{l}\text { Northern Serra } \\
\text { do Mar }\end{array}$ & ephippium & $\begin{array}{l}\text { Serra de Macaé }\left(22^{\circ} 18^{\prime} 02^{\prime} \mathrm{S} \text {, }\right. \\
\left.42^{\circ} 18^{\prime} 20^{\prime} \mathrm{W}\right) \text {, municipality of Nova } \\
\text { Friburgo }\end{array}$ & $\mathrm{RJ}$ & $\begin{array}{c}? \\
(1,100 ?)\end{array}$ & $\begin{array}{l}\text { Miranda-Ribeiro (1920), Pombal } \\
\text { (2010), Pombal \& Izecksohn } \\
\text { (2011) }\end{array}$ \\
\hline B. garbeanus & $\begin{array}{l}\text { Northern Serra } \\
\text { do Mar }\end{array}$ & ephippium & $\begin{array}{l}\text { Serra Nevada }\left(22^{\circ} 21^{\prime} 46^{\prime} \mathrm{S},\right. \\
\left.42^{\circ} 32^{\prime} 48^{\prime \prime} \mathrm{W}\right) \text {, municipality of Nova } \\
\text { Friburgo }\end{array}$ & $\mathrm{RJ}$ & 1,190 & Pombal \& Izecksohn (2011) \\
\hline B. garbeanus & $\begin{array}{l}\text { Northern Serra } \\
\text { do Mar }\end{array}$ & ephippium & $\begin{array}{l}\text { Theodoro de Oliveira (second } \\
\text { position: } 22^{\circ} 21^{\prime} 48^{\prime \prime} \mathrm{S}, 42^{\circ} 33^{\prime} 13^{\prime \prime} \mathrm{W} \text { ), } \\
\text { Parque Estadual dos Três Picos, } \\
\text { municipality of Nova Friburgo }\end{array}$ & $\mathrm{RJ}$ & 1,400 & $\begin{array}{l}\text { Pombal \& Izecksohn (2011), } \\
\text { Siqueira et al. (2011, 2013) }\end{array}$ \\
\hline B. guarani & $\begin{array}{l}\text { Central Serra } \\
\text { do Mar }\end{array}$ & ephippium & $\begin{array}{l}\text { Morro Prumirim }\left(23^{\circ} 20^{\prime} 50^{\prime} \mathrm{S} \text {, }\right. \\
\left.45^{\circ} 01^{\prime} 37^{\prime \prime} \mathrm{W}\right), \text { municipality of } \\
\text { Ubatuba }\end{array}$ & SP & $\begin{array}{c}500- \\
900\end{array}$ & $\begin{array}{l}\text { Giaretta (1999; altitude } \\
\text { determined by Clemente- } \\
\text { Carvalho et al. [2012]), } \\
\text { Clemente-Carvalho et al. (2012), } \\
\text { Condez et al. (2014) }\end{array}$ \\
\hline B. margaritatus & $\begin{array}{l}\text { Northern Serra } \\
\text { do Mar }\end{array}$ & ephippium & $\begin{array}{l}\text { Castelo Country Club }\left(22^{\circ} 32^{\prime} 21^{\prime} \mathrm{S} \text {, }\right. \\
\left.43^{\circ} 13^{\prime} 08^{\prime} \mathrm{W}\right) \text {, municipality of } \\
\text { Petrópolis }\end{array}$ & RJ & 980 & Pombal \& Izecksohn (2011) \\
\hline B. margaritatus & $\begin{array}{l}\text { Northern Serra } \\
\text { do Mar }\end{array}$ & ephippium & $\begin{array}{l}\text { Castelo Montebello }\left(22^{\circ} 24^{\prime} 24^{\prime \prime} \mathrm{S} \text {, }\right. \\
\left.42^{\circ} 58^{\prime} 06^{\prime} \mathrm{W}\right) \text {, municipality of } \\
\text { Teresópolis }\end{array}$ & $\mathrm{RJ}$ & 920 & Pombal \& Izecksohn (2011) \\
\hline B. margaritatus & $\begin{array}{l}\text { Northern Serra } \\
\text { do Mar }\end{array}$ & ephippium & $\begin{array}{l}\text { Independência }\left(22^{\circ} 32^{\prime} 58^{\prime} \mathrm{S} \text {, }\right. \\
\left.43^{\circ} 12^{\prime} 27^{\prime \prime} \mathrm{W}\right) \text {, municipality of } \\
\text { Petrópolis }\end{array}$ & $\mathrm{RJ}$ & 860 & Pombal \& Izecksohn (2011) \\
\hline
\end{tabular}




\begin{tabular}{|c|c|c|c|c|c|c|}
\hline Species $^{1}$ & Relief units ${ }^{2}$ & Group $^{3}$ & Locality $^{4}$ & State & Altitude & Source 5 \\
\hline B. margaritatus & $\begin{array}{l}\text { Northern Serra } \\
\text { do Mar }\end{array}$ & ephippium & $\begin{array}{l}\text { Morro Azul }\left(22^{\circ} 28^{\prime} 34^{\prime \prime} \text {, }\right. \\
\left.43^{\circ} 34^{\prime} 40^{\prime \prime} \mathrm{W}\right) \text {, municipality of } \\
\text { Engenheiro Paulo de Frontin }\end{array}$ & $\mathrm{RJ}$ & 620 & $\begin{array}{l}\text { Campos (2011; as “BPF RJ2”), } \\
\text { Pombal \& Izecksohn (2011) }\end{array}$ \\
\hline B. margaritatus & $\begin{array}{l}\text { Northern Serra } \\
\text { do Mar }\end{array}$ & ephippium & $\begin{array}{l}\text { Quitandinha }\left(22^{\circ} 31^{\prime} 47^{\prime} \mathrm{S} \text {, }\right. \\
\left.43^{\circ} 12^{\prime} 26^{\prime} \mathrm{W}\right) \text {, municipality of } \\
\text { Petrópolis }\end{array}$ & $\mathrm{RJ}$ & 925 & Pombal \& Izecksohn (2011) \\
\hline B. margaritatus & $\begin{array}{l}\text { Northern Serra } \\
\text { do Mar }\end{array}$ & ephippium & $\begin{array}{l}\text { Sacra Família do Tinguá } \\
\left(22^{\circ} 29^{\prime} 11^{\prime} \mathrm{S}, 43^{\circ} 36^{\prime} 18^{\prime \prime} \mathrm{W}\right) \\
\text { municipality of Engenheiro Paulo de } \\
\text { Frontin }\end{array}$ & RJ & 600 & $\begin{array}{l}\text { Izecksohn (1971; as "B. } \\
\text { ephippium"), Pombal (2001; as } \\
\text { "Brachycephalus cf. ephippium"), } \\
\text { Pombal \& Izecksohn (2011), Pie } \\
\text { et al. (2013; as "B. ephippium") }\end{array}$ \\
\hline B. nodoterga & $\begin{array}{l}\text { Central Serra } \\
\text { do Mar }\end{array}$ & ephippium & $\begin{array}{l}\text { Estação Biológica de Boracéia } \\
\text { (second position: } 23^{\circ} 38^{\prime} 00^{\prime} \mathrm{S} \text {, } \\
\left.45^{\circ} 52^{\prime} 00^{\prime} \mathrm{W}\right) \text {, municipality of } \\
\text { Salesópolis }\end{array}$ & SP & 945 & $\begin{array}{l}\text { Pombal et al. (1998), Pombal } \\
\text { (2001, 2010), Ribeiro et al. } \\
\text { (2005), Alves et al. (2006, 2009), } \\
\text { Haddad et al. (2010), Pombal \& } \\
\text { Izecksohn (2011), Pie et al. } \\
\text { (2013), Abegg et al. (2015), } \\
\text { Clemente-Carvalho et al. (2016) }\end{array}$ \\
\hline B. nodoterga & $\begin{array}{l}\text { Central Serra } \\
\text { do Mar }\end{array}$ & ephippium & $\begin{array}{l}\text { Fazenda Paiva Ramos }\left(23^{\circ} 28^{\prime} 21^{\prime} \text { S, }\right. \\
\left.46^{\circ} 47^{\prime} 25^{\prime \prime} \mathrm{W}\right) \text {, Serra de São Roque, } \\
\text { municipality of Osasco }\end{array}$ & SP & 820 & Abegg et al. (2015) \\
\hline
\end{tabular}




\begin{tabular}{|c|c|c|c|c|c|c|}
\hline Species $^{1}$ & Relief units ${ }^{2}$ & Group $^{3}$ & Locality $^{4}$ & State & Altitude & Source 5 \\
\hline B. nodoterga & $\begin{array}{l}\text { Central Serra } \\
\text { do Mar }\end{array}$ & ephippium & $\begin{array}{l}\text { Pico do Ramalho ( } 23^{\circ} 51^{\prime} 42^{\prime} \text { S, } \\
\left.45^{\circ} 21^{\prime} 28^{\prime} \mathrm{W}\right) \text {, Ilha de São Sebastião, } \\
\text { municipality of Ilhabela }\end{array}$ & SP & $\begin{array}{c}700- \\
900\end{array}$ & $\begin{array}{l}\text { Ribeiro (2006; as } \\
\text { "Brachycephalus sp. aff. } \\
\text { nodoterga"), Pombal \& } \\
\text { Izecksohn (2011), Pie et al. } \\
\text { (2013), Abegg et al. (2015), } \\
\text { Clemente-Carvalho et al. (2016) }\end{array}$ \\
\hline B. nodoterga & $\begin{array}{l}\text { Central Serra } \\
\text { do Mar }\end{array}$ & ephippium & $\begin{array}{l}\text { Serra da Cantareira }\left(23^{\circ} 27^{\prime} 13 ” S \text {, }\right. \\
\left.46^{\circ} 38^{\prime} 11^{\prime \prime}\right) \text {, Parque Estadual da } \\
\text { Cantareira, municipality of São Paulo }\end{array}$ & SP & $?(850 ?)$ & $\begin{array}{l}\text { Miranda-Ribeiro (1920), Ribeiro } \\
\text { et al. (2005), Alves et al. (2006, } \\
\text { 2009), Clemente-Carvalho et al. } \\
\text { (2009, 2011a, 2012, 2016), } \\
\text { Haddad et al. (2010), Pombal } \\
\text { (2010), Pombal \& Izecksohn } \\
\text { (2011), Condez et al. (2014), } \\
\text { Abegg et al. (2015) }\end{array}$ \\
\hline B. pitanga & $\begin{array}{l}\text { Central Serra } \\
\text { do Mar }\end{array}$ & ephippium & $\begin{array}{l}\text { Fazenda Capricórnio }\left(23^{\circ} 22^{\prime} 36^{\prime} \mathrm{S},\right. \\
\left.45^{\circ} 04^{\prime} 07^{\prime \prime} \mathrm{W}\right) \text {, municipality of } \\
\text { Ubatuba }\end{array}$ & SP & $?(450 ?)$ & $\begin{array}{l}\text { Alves et al. (2009), Campos et al. } \\
\text { (2010; as “Brachycephalus sp. } \\
\text { 2"), Campos (2011), Pie et al. } \\
\text { (2013) }\end{array}$ \\
\hline B. pitanga & $\begin{array}{l}\text { Central Serra } \\
\text { do Mar }\end{array}$ & ephippium & $\begin{array}{l}\text { Núcleo Santa Virgínia }\left(23^{\circ} 19^{\prime} 23^{\prime} \text { S, }\right. \\
\left.45^{\circ} 05^{\prime} 19^{\prime} \mathrm{W}\right) \text {, Parque Estadual da } \\
\text { Serra do Mar, municipality of São } \\
\text { Luis do Paraitinga }\end{array}$ & SP & $\begin{array}{l}980- \\
1,140\end{array}$ & $\begin{array}{l}\text { Oliveira (2013), Tandel et al. } \\
\text { (2014), Oliveira \& Haddad } \\
(2015)\end{array}$ \\
\hline B. pitanga & $\begin{array}{l}\text { Central Serra } \\
\text { do Mar }\end{array}$ & ephippium & $\begin{array}{l}\text { SP } 125 \text { - municipality of São Luís do } \\
\text { Paraitinga }\left(23^{\circ} 22^{\prime} 57^{\prime} \mathrm{S}, 45^{\circ} 09^{\prime} 59^{\prime \prime} \mathrm{W}\right)\end{array}$ & SP & $\begin{array}{c}935- \\
950\end{array}$ & *, DZUP \\
\hline
\end{tabular}




\begin{tabular}{|c|c|c|c|c|c|c|}
\hline Species $^{1}$ & Relief units ${ }^{2}$ & Group $^{3}$ & Locality ${ }^{4}$ & State & Altitude & Source $^{5}$ \\
\hline B. pitanga & $\begin{array}{l}\text { Central Serra } \\
\text { do Mar }\end{array}$ & ephippium & $\begin{array}{l}\text { Trilha do Ipiranga } 50 \mathrm{~m} \text { from the Rio } \\
\text { Ipiranga }\left(23^{\circ} 20^{\prime} 39^{\prime} \mathrm{S}, 45^{\circ} 08^{\prime} 16^{\prime} \mathrm{W}\right) \text {, } \\
\text { Núcleo Santa Virgínia, Parque } \\
\text { Estadual da Serra do Mar, } \\
\text { municipality of São Luis do } \\
\text { Paraitinga }\end{array}$ & SP & $\begin{array}{c}900- \\
960\end{array}$ & $\begin{array}{l}\text { Alves et al. (2009), Clemente- } \\
\text { Carvalho et al. (2009, 2011a), } \\
\text { Araújo et al. (2012), Oliveira } \\
\text { (2013), Pie et al. (2013) }\end{array}$ \\
\hline B. toby & $\begin{array}{l}\text { Central Serra } \\
\text { do Mar }\end{array}$ & ephippium & $\begin{array}{l}\text { Morro do Corcovado }\left(23^{\circ} 27^{\prime} 20^{\prime} \text { 'S, }\right. \\
\left.45^{\circ} 11^{\prime} 49^{\prime \prime} \mathrm{W}\right) \text {, Parque Estadual da } \\
\text { Serra do Mar, municipality of } \\
\text { Ubatuba }\end{array}$ & SP & 750 & $\begin{array}{l}\text { Haddad et al. (2010), Clemente- } \\
\text { Carvalho et al. (2011a, 2012), Pie } \\
\text { et al. (2013), Condez et al. (2014) }\end{array}$ \\
\hline B. vertebralis & $\begin{array}{l}\text { Central Serra } \\
\text { do Mar }\end{array}$ & ephippium & $\begin{array}{l}\text { Morro Cuzcuzeiro }\left(23^{\circ} 18^{\prime} 03^{\prime} \text { 'S, }\right. \\
\left.44^{\circ} 47^{\prime} 30^{\prime} \mathrm{W}\right) \text {, Núcleo Picinguaba, } \\
\text { Parque Estadual da Serra do Mar, } \\
\text { municipality of Ubatuba }\end{array}$ & SP & 900 & $\begin{array}{l}\text { Clemente-Carvalho et al. (2011a), } \\
\text { Pie et al. (2013), Condez et al. } \\
\text { (2014) }\end{array}$ \\
\hline B. vertebralis & $\begin{array}{l}\text { Central Serra } \\
\text { do Mar }\end{array}$ & ephippium & $\begin{array}{l}\text { Pedra Branca }\left(23^{\circ} 10^{\prime} 38^{\prime} \mathrm{S},\right. \\
\left.44^{\circ} 47^{\prime} 19^{\prime} \mathrm{W}\right) \text {, Serra da Bocaina, } \\
\text { municipality of Parati }\end{array}$ & $\mathrm{RJ}$ & $?(630 ?)$ & $\begin{array}{l}\text { Pombal (2001, 2010), Clemente- } \\
\text { Carvalho et al. (2009), Pie et al. } \\
\text { (2013) }\end{array}$ \\
\hline $\begin{array}{l}\text { Brachycephalus sp. } \\
2\end{array}$ & $\begin{array}{l}\text { Northern Serra } \\
\text { do Mar }\end{array}$ & ephippium & $\begin{array}{l}\text { Theodoro de Oliveira (first position: } \\
22^{\circ} 22^{\prime} 11^{\prime \prime} \mathrm{S}, 42^{\circ} 33^{\prime} 25^{\prime} \mathrm{W} \text { ), Parque } \\
\text { Estadual dos Três Picos, municipality } \\
\text { of Nova Friburgo }\end{array}$ & $\mathrm{RJ}$ & $\begin{array}{c}1,100- \\
1,200\end{array}$ & $\begin{array}{l}\text { Siqueira et al. (2011 [as } \\
\text { "Brachycephalus sp.”], } 2013 \text { [as } \\
\text { "Brachycephalus sp. nov.”]) }\end{array}$ \\
\hline $\begin{array}{l}\text { Brachycephalus sp. } \\
3\end{array}$ & $\begin{array}{l}\text { Central Serra } \\
\text { do Mar }\end{array}$ & ephippium & $\begin{array}{l}\text { Paranapiacaba }\left(23^{\circ} 46^{\prime} 30^{\prime \prime} \mathrm{S} \text {, }\right. \\
\left.46^{\circ} 17^{\prime} 57^{\prime} \mathrm{W}\right) \text {, municipality of Santo } \\
\text { André }\end{array}$ & SP & 825 & $\begin{array}{l}\text { Pombal \& Izecksohn (2011; as } \\
\text { "B. ephippium"), Pie et al. (2013; } \\
\text { as "Brachycephalus sp. 1") }\end{array}$ \\
\hline
\end{tabular}




\begin{tabular}{|c|c|c|c|c|c|c|}
\hline Species $^{1}$ & Relief units ${ }^{2}$ & Group $^{3}$ & Locality $^{4}$ & State & Altitude & Source 5 \\
\hline $\begin{array}{l}\text { Brachycephalus sp. } \\
3\end{array}$ & $\begin{array}{l}\text { Central Serra } \\
\text { do Mar }\end{array}$ & ephippium & $\begin{array}{l}\text { Parque Natural Municipal Nascentes } \\
\text { de Paranapiacaba ( } 23^{\circ} 46^{\prime} 10^{\prime \prime} S \text {, } \\
\left.46^{\circ} 17^{\prime} 36^{\prime} \mathrm{W}\right) \text {, municipality of Santo } \\
\text { André }\end{array}$ & SP & $\begin{array}{l}?(800- \\
1,164 ?)\end{array}$ & $\begin{array}{l}\text { Trevine et al. (2014; as } \\
\text { "Brachycephalus sp.") }\end{array}$ \\
\hline $\begin{array}{l}\text { Brachycephalus sp. } \\
3\end{array}$ & $\begin{array}{l}\text { Central Serra } \\
\text { do Mar }\end{array}$ & ephippium & $\begin{array}{l}\text { Reserva Biológica do Alto da Serra } \\
\text { de Paranapiacaba ( } 23^{\circ} 46^{\prime} 40^{\prime} \text { 'S, } \\
\left.46^{\circ} 18^{\prime} 45^{\prime} \mathrm{W}\right) \text {, municipality of Santo } \\
\text { André }\end{array}$ & SP & 800 & $\begin{array}{l}\text { Pie et al. (2013; as } \\
\text { "Brachycephalus sp. 1") }\end{array}$ \\
\hline B. auroguttatus & $\begin{array}{l}\text { Southern Serra } \\
\text { do Mar }\end{array}$ & pernix & $\begin{array}{l}\text { Pedra da Tartaruga }\left(26^{\circ} 00^{\prime} 21^{\prime \prime} \mathrm{S},\right. \\
\left.48^{\circ} 55^{\prime} 25^{\prime} \mathrm{W}\right) \text {, municipality of Garuva }\end{array}$ & $\mathrm{SC}$ & $\begin{array}{c}1,070- \\
1,100\end{array}$ & $\begin{array}{l}\text { *, DZUP, Firkowski ( } 2013 ; \\
\text { without species identification), } \\
\text { Ribeiro et al. (2015) }\end{array}$ \\
\hline B. boticario & $\begin{array}{l}\text { Leste } \\
\text { Catarinense }\end{array}$ & pernix & $\begin{array}{l}\text { Morro do Cachorro }\left(26^{\circ} 46^{\prime} 42^{\prime} \mathrm{S} \text {, }\right. \\
\left.49^{\circ} 01^{\prime} 57^{\prime \prime W}\right) \text {, boundary of the } \\
\text { municipalities of Blumenau, Gaspar, } \\
\text { and Luiz Alves }\end{array}$ & $\mathrm{SC}$ & $\begin{array}{l}755- \\
795\end{array}$ & $\begin{array}{l}\text { *, DZUP, Firkowski ( } 2013 ; \\
\text { without species identification), } \\
\text { Ribeiro et al. (2015) }\end{array}$ \\
\hline B. brunneus & $\begin{array}{l}\text { Southern Serra } \\
\text { do Mar }\end{array}$ & pernix & $\begin{array}{l}\text { Camapuã }\left(25^{\circ} 15^{\prime} 59^{\prime \prime} \mathrm{S}, 48^{\circ} 50^{\prime} 16^{\prime \prime} \mathrm{W}\right) \text {, } \\
\text { Serra dos Órgãos, boundary of the } \\
\text { municipalities of Campina Grande do } \\
\text { Sul and Antonina }\end{array}$ & PR & 1,595 & $\begin{array}{l}\text { Fontoura et al. (2011), Firkowski } \\
\text { (2013; without species } \\
\text { identification), Pie et al. (2013) }\end{array}$ \\
\hline B. brunneus & $\begin{array}{l}\text { Southern Serra } \\
\text { do Mar }\end{array}$ & pernix & $\begin{array}{l}\text { Caranguejeira }\left(25^{\circ} 20^{\prime} 27^{\prime} \mathrm{S},\right. \\
\left.48^{\circ} 54^{\prime} 31^{\prime} \mathrm{W}\right) \text {, Serra da Graciosa, } \\
\text { municipality of Quatro Barras }\end{array}$ & PR & $\begin{array}{c}1,095- \\
1,110\end{array}$ & $\begin{array}{l}*, \text { DZUP, Firkowski (2013; } \\
\text { without species identification) }\end{array}$ \\
\hline
\end{tabular}




\begin{tabular}{|c|c|c|c|c|c|c|}
\hline Species $^{1}$ & Relief units ${ }^{2}$ & Group $^{3}$ & Locality $^{4}$ & State & Altitude & Source 5 \\
\hline B. brunneus & $\begin{array}{l}\text { Southern Serra } \\
\text { do Mar }\end{array}$ & pernix & $\begin{array}{l}\left.\text { Caratuva ( } 25^{\circ} 14^{\prime} 33^{\prime} \mathrm{S}, 48^{\circ} 50^{\prime} 04^{\prime} \mathrm{W}\right) \text {, } \\
\text { Serra dos Orgãos, municipality of } \\
\text { Campina Grande do Sul }\end{array}$ & PR & $\begin{array}{c}1,300- \\
1,630\end{array}$ & $\begin{array}{l}\text { Ribeiro et al. (2005), Clemente- } \\
\text { Carvalho et al. (2009, } 2011 \mathrm{a}) \text {, } \\
\text { Campos (2011), Fontoura et al. } \\
\text { (2011), Pombal \& Izecksohn } \\
\text { (2011; including "Pico Paraná"), } \\
\text { Firkowski (2013; without species } \\
\text { identification; including "Pico } \\
\text { Paraná"), Pie et al. (2013) }\end{array}$ \\
\hline B. brunneus & $\begin{array}{l}\text { Southern Serra } \\
\text { do Mar }\end{array}$ & pernix & $\begin{array}{l}\left.\text { Getúlio ( } 25^{\circ} 14^{\prime} 18^{\prime} \mathrm{S}, 48^{\circ} 50^{\prime} 13^{\prime} \mathrm{W}\right) \text {, } \\
\text { Serra dos Órgãos, municipality of } \\
\text { Campina Grande do Sul }\end{array}$ & PR & $\begin{array}{c}1,450- \\
1,490\end{array}$ & *, Pie et al. (2013) \\
\hline B. brunneus & $\begin{array}{l}\text { Southern Serra } \\
\text { do Mar }\end{array}$ & pernix & $\begin{array}{l}\text { Mãe Catira }\left(25^{\circ} 20^{\prime} 51^{\prime} \mathrm{S} \text {, }\right. \\
\left.48^{\circ} 54^{\prime} 25^{\prime} \mathrm{W}\right) \text {, Serra da Graciosa, } \\
\text { municipality of Quatro Barras }\end{array}$ & PR & $\begin{array}{l}1,135- \\
1,405\end{array}$ & $\begin{array}{l}\text { Firkowski (2013; without species } \\
\text { identification), Pie et al. (2013; as } \\
\text { "Brachycephalus sp. nov. 2") }\end{array}$ \\
\hline B. brunneus & $\begin{array}{l}\text { Southern Serra } \\
\text { do Mar }\end{array}$ & pernix & $\begin{array}{l}\left.\text { Tupipiá ( } 25^{\circ} 14^{\prime} 31^{\prime \prime} \mathrm{S}, 48^{\circ} 47^{\prime} 47^{\prime \prime} \mathrm{W}\right) \text {, } \\
\text { Serra dos Órgãos, municipality of } \\
\text { Antonina }\end{array}$ & PR & 1,260 & $\begin{array}{l}\text { Firkowski (2013; without species } \\
\text { identification), Pie et al. (2013) }\end{array}$ \\
\hline B. ferruginus & $\begin{array}{l}\text { Southern Serra } \\
\text { do Mar }\end{array}$ & pernix & $\begin{array}{l}\text { Olimpo }\left(25^{\circ} 27^{\prime} 03 ’ \mathrm{~S}, 48^{\circ} 54^{\prime} 59^{\prime \prime} \mathrm{W}\right) \text {, } \\
\text { Serra do Marumbi, municipality of } \\
\text { Morretes }\end{array}$ & PR & $\begin{array}{l}965- \\
1,470\end{array}$ & $\begin{array}{l}\text { Alves et al. (2006), Clemente- } \\
\text { Carvalho et al. (2009, 2011a), } \\
\text { Pombal \& Izecksohn (2011), } \\
\text { Firkowski (2013; without species } \\
\text { identification), Pie et al. (2013) }\end{array}$ \\
\hline
\end{tabular}




\begin{tabular}{|c|c|c|c|c|c|c|}
\hline Species $^{1}$ & Relief units ${ }^{2}$ & Group $^{3}$ & Locality $^{4}$ & State & Altitude & Source 5 \\
\hline B. fuscolineatus & $\begin{array}{l}\text { Leste } \\
\text { Catarinense }\end{array}$ & pernix & $\begin{array}{l}\text { Morro do Baú }\left(26^{\circ} 47^{\prime} 58^{\prime \prime} \mathrm{S} \text {, }\right. \\
\left.48^{\circ} 55^{\prime} 47^{\prime} \mathrm{W}\right) \text {, municipality of Ilhota }\end{array}$ & $\mathrm{SC}$ & $\begin{array}{c}640- \\
790\end{array}$ & $\begin{array}{l}\text { Firkowski (2013; without species } \\
\text { identification), Pie et al. (2013; as } \\
\text { "Brachycephalus sp. nov. 9"), } \\
\text { Ribeiro et al. (2015) }\end{array}$ \\
\hline B. izecksohni & $\begin{array}{l}\text { Southern Serra } \\
\text { do Mar }\end{array}$ & pernix & $\begin{array}{l}\text { Torre da Prata, Serra da Prata } \\
\left(25^{\circ} 37^{\prime} 25^{\prime} \mathrm{S}, 48^{\circ} 41^{\prime} 31^{\prime} \mathrm{W}\right) \text {, boundary } \\
\text { of the municipalities of Morretes, } \\
\text { Paranaguá, and Guaratuba }\end{array}$ & PR & $\begin{array}{l}980- \\
1,340\end{array}$ & $\begin{array}{l}\text { Ribeiro et al. (2005), Clemente- } \\
\text { Carvalho et al. (2009, 2011a), } \\
\text { Pombal \& Izecksohn (2011), } \\
\text { Firkowski (2013; without species } \\
\text { identification), Pie et al. (2013) }\end{array}$ \\
\hline B. leopardus & $\begin{array}{l}\text { Southern Serra } \\
\text { do Mar }\end{array}$ & pernix & $\begin{array}{l}\text { Morro dos Perdidos }\left(25^{\circ} 53^{\prime} 22^{\prime} \mathrm{S},\right. \\
\left.48^{\circ} 57^{\prime} 22^{\prime \prime} \mathrm{W}\right) \text {, municipality of } \\
\text { Guaratuba }\end{array}$ & PR & $\begin{array}{c}1,400- \\
1,420\end{array}$ & $\begin{array}{l}\text { Firkowski (2013; without species } \\
\text { identification), Pie et al. (2013; as } \\
\text { "Brachycephalus sp. nov. 4") }\end{array}$ \\
\hline B. leopardus & $\begin{array}{l}\text { Southern Serra } \\
\text { do Mar }\end{array}$ & pernix & $\begin{array}{l}\text { Serra do Araçatuba }\left(25^{\circ} 54^{\prime} 07^{\prime} \text { S, }\right. \\
\left.48^{\circ} 59^{\prime} 47^{\prime} \mathrm{W}\right) \text {, municipality of Tijucas } \\
\text { do Sul }\end{array}$ & PR & 1,640 & $\begin{array}{l}\text { Firkowski (2013; without species } \\
\text { identification), Pie et al. (2013; as } \\
\text { "Brachycephalus sp. nov. 4"), } \\
\text { Ribeiro et al. (2015) }\end{array}$ \\
\hline B. mariaeterezae & $\begin{array}{l}\text { Southern Serra } \\
\text { do Mar }\end{array}$ & pernix & $\begin{array}{l}\text { Reserva Particular do Patrimônio } \\
\text { Natural Caetezal, top of the Serra } \\
\text { Queimada }\left(26^{\circ} 066^{\prime} 51^{\prime \prime S} \text {, }\right. \\
49^{\circ} 03 \text { ' } 45^{\prime} \text { 'W), municipality of } \\
\text { Joinville }\end{array}$ & $\mathrm{SC}$ & $\begin{array}{c}1,265- \\
1,270\end{array}$ & $\begin{array}{l}\text { Firkowski (2013; without species } \\
\text { identification), Pie et al. (2013; as } \\
\text { "Brachycephalus sp. nov. 6"), } \\
\text { Ribeiro et al. (2015) }\end{array}$ \\
\hline B. olivaceus & $\begin{array}{l}\text { Southern Serra } \\
\text { do Mar }\end{array}$ & pernix & $\begin{array}{l}\text { Castelo dos Bugres (second position: } \\
26^{\circ} 13 \text { '59”S, } 49^{\circ} 03 \text { '13”W) } \\
\text { municipality of Joinville }\end{array}$ & $\mathrm{SC}$ & $\begin{array}{l}800- \\
835\end{array}$ & $\begin{array}{l}\text { Firkowski (2013; without species } \\
\text { identification), Pie et al. (2013; as } \\
\text { "Brachycephalus sp. nov. 7"), } \\
\text { Ribeiro et al. (2015) }\end{array}$ \\
\hline
\end{tabular}




\begin{tabular}{|c|c|c|c|c|c|c|}
\hline Species $^{1}$ & Relief units ${ }^{2}$ & Group $^{3}$ & Locality $^{4}$ & State & Altitude & Source 5 \\
\hline B. olivaceus & $\begin{array}{l}\text { Southern Serra } \\
\text { do Mar }\end{array}$ & pernix & $\begin{array}{l}\text { Base of the Serra Queimada } \\
\left(26^{\circ} 04^{\prime} 57^{\prime} \mathrm{S}, 49^{\circ} 03^{\prime} 59^{\prime} \mathrm{W}\right) \\
\text { municipality of Joinville }\end{array}$ & $\mathrm{SC}$ & 985 & $\begin{array}{l}\text { Pie et al. (2013; as } \\
\text { "Brachycephalus sp. nov. 7”), } \\
\text { Ribeiro et al. (2015) }\end{array}$ \\
\hline B. olivaceus & $\begin{array}{l}\text { Leste } \\
\text { Catarinense }\end{array}$ & Pernix & $\begin{array}{l}\text { Morro do Boi }\left(26^{\circ} 24^{\prime} 42^{\prime} \text { S, }\right. \\
\left.49^{\circ} 12^{\prime} 59^{\prime} \mathrm{W}\right) \text {, municipality of Corupá }\end{array}$ & $\mathrm{SC}$ & $\begin{array}{c}690- \\
920\end{array}$ & $\begin{array}{l}\text { *, MHNCI, Pie et al. (2013; as } \\
\text { "Brachycephalus sp. 3") }\end{array}$ \\
\hline B. pernix & $\begin{array}{l}\text { Southern Serra } \\
\text { do Mar }\end{array}$ & pernix & $\begin{array}{l}\text { Anhangava }\left(25^{\circ} 23^{\prime} 19^{\prime} \mathrm{S},\right. \\
\left.49^{\circ} 00^{\prime} 15^{\prime} \mathrm{W}\right) \text {, Serra da Baitaca, } \\
\text { municipality of Quatro Barras, }\end{array}$ & PR & $\begin{array}{l}1,135- \\
1,405\end{array}$ & $\begin{array}{l}\text { Pombal et al. (1998), Wistuba } \\
\text { (1998), Pires et al. (2005), Silva } \\
\text { et al. (2007), Clemente-Carvalho } \\
\text { et al. (2009, 2011a), Campos et } \\
\text { al. (2010), Campos (2011), } \\
\text { Pombal \& Izecksohn (2011), } \\
\text { Firkowski (2013; without species } \\
\text { identification), Pie et al. (2013), } \\
\text { Ribeiro et al. (2014) }\end{array}$ \\
\hline B. pombali & $\begin{array}{l}\text { Southern Serra } \\
\text { do Mar }\end{array}$ & pernix & $\begin{array}{l}\text { Morro dos Padres }\left(25^{\circ} 36^{\prime} 40^{\prime} \mathrm{S} \text {, }\right. \\
\left.48^{\circ} 51^{\prime} 22^{\prime \prime} \mathrm{W}\right) \text {, Serra da Igreja, } \\
\text { municipality of Morretes }\end{array}$ & PR & $\begin{array}{c}1,060- \\
1,300\end{array}$ & $\begin{array}{l}\text { Alves et al. (2006), Clemente- } \\
\text { Carvalho et al. (2009, } 2011 \mathrm{a}) \text {, } \\
\text { Firkowski (2013; without species } \\
\text { identification), Pie et al. (2013) }\end{array}$ \\
\hline B. pombali & $\begin{array}{l}\text { Southern Serra } \\
\text { do Mar }\end{array}$ & pernix & $\begin{array}{l}\text { trail to Morro dos Padres } \\
\left(25^{\circ} 35^{\prime} 58^{\prime} \mathrm{S}, 48^{\circ} 51^{\prime} 57^{\prime} \mathrm{W}\right) \\
\text { municipality of Morretes }\end{array}$ & PR & $\begin{array}{l}845- \\
1,060\end{array}$ & Pie et al. (2013) \\
\hline B. quiririensis & $\begin{array}{l}\text { Southern Serra } \\
\text { do Mar }\end{array}$ & pernix & $\begin{array}{l}\text { Serra do Quiriri }\left(26^{\circ} 01^{\prime} 17^{\prime} \text { 'S, }\right. \\
\left.48^{\circ} 59^{\prime} 47^{\prime} \mathrm{W}\right) \text {, municipality of Campo } \\
\text { Alegre }\end{array}$ & $\mathrm{SC}$ & $\begin{array}{c}1,240- \\
1,318\end{array}$ & $\begin{array}{l}\text { Firkowski (2013; without species } \\
\text { identification), Pie et al. (2013; as } \\
\text { "Brachycephalus sp. nov. 5"), Pie } \\
\text { \& Ribeiro (2015) }\end{array}$ \\
\hline
\end{tabular}




\begin{tabular}{|c|c|c|c|c|c|c|}
\hline Species $^{1}$ & Relief units ${ }^{2}$ & Group $^{3}$ & Locality $^{4}$ & State & Altitude & Source 5 \\
\hline B. quiririensis & $\begin{array}{l}\text { Southern Serra } \\
\text { do Mar }\end{array}$ & pernix & $\begin{array}{l}\text { Serra do Quiriri }\left(26^{\circ} 01 ’ 42^{\prime \prime} \mathrm{S} \text {, }\right. \\
\left.48^{\circ} 57^{\prime} 11^{\prime} \mathrm{W}\right) \text {, municipality of Garuva }\end{array}$ & $\mathrm{SC}$ & $\begin{array}{c}1,320 \\
1,380\end{array}$ & $\begin{array}{l}\text { Pie et al. (2013; as } \\
\text { "Brachycephalus sp. nov. 5"), Pie } \\
\text { \& Ribeiro (2015) }\end{array}$ \\
\hline B. tridactylus & $\begin{array}{l}\text { Southern Serra } \\
\text { do Mar }\end{array}$ & pernix & $\begin{array}{l}\text { Serra do Morato }\left(25^{\circ} 08^{\prime} 09^{\prime} \text { 'S, }\right. \\
\left.48^{\circ} 17^{\prime} 59^{\prime \prime} \mathrm{W}\right) \text {, Reserva Natural Salto } \\
\text { Morato, municipality of } \\
\text { Guaraqueçaba }\end{array}$ & PR & $\begin{array}{c}805- \\
910\end{array}$ & $\begin{array}{l}*, \text { DZUP, Garey et al. (2012), } \\
\text { Bornschein et al. (2015) }\end{array}$ \\
\hline B. verrucosus & $\begin{array}{l}\text { Southern Serra } \\
\text { do Mar }\end{array}$ & pernix & $\begin{array}{l}\text { Morro da Tromba }\left(26^{\circ} 12^{\prime} 44^{\prime \prime} \mathrm{S} \text {, }\right. \\
\left.48^{\circ} 57^{\prime} 29^{\prime} \mathrm{W}\right) \text {, municipality of } \\
\text { Joinville }\end{array}$ & $\mathrm{SC}$ & $\begin{array}{l}455- \\
945\end{array}$ & $\begin{array}{l}\text { Firkowski (2013; without species } \\
\text { identification), Pie et al. (2013; as } \\
\text { "Brachycephalus sp. nov. 8"), } \\
\text { Ribeiro et al. (2015) }\end{array}$ \\
\hline $\begin{array}{l}\text { Brachycephalus sp. } \\
4\end{array}$ & $\begin{array}{l}\text { Southern Serra } \\
\text { do Mar }\end{array}$ & pernix & $\begin{array}{l}\text { Morro do Canal }\left(25^{\circ} 30^{\prime} 55^{\prime} \text { 'S, }\right. \\
\left.48^{\circ} 58^{\prime} 56^{\prime \prime} \mathrm{W}\right) \text {, municipality of } \\
\text { Piraquara }\end{array}$ & PR & 1,320 & $\begin{array}{l}\text { DZUP, Firkowski (2013; without } \\
\text { species identification) }\end{array}$ \\
\hline $\begin{array}{l}\text { Brachycephalus sp. } \\
4\end{array}$ & $\begin{array}{l}\text { Southern Serra } \\
\text { do Mar }\end{array}$ & pernix & $\begin{array}{l}\text { Morro do Vigia }\left(25^{\circ} 30^{\prime} 33^{\prime} \mathrm{S} \text {, }\right. \\
\left.48^{\circ} 58^{\prime} 58^{\prime \prime} \mathrm{W}\right), \text { municipality of } \\
\text { Piraquara }\end{array}$ & PR & 1,250 & $\begin{array}{l}\text { Firkowski (2013; without species } \\
\text { identification), Pie et al. (2013; as } \\
\text { "Brachycephalus sp. nov. 3") }\end{array}$ \\
\hline $\begin{array}{l}\text { Brachycephalus sp. } \\
5\end{array}$ & $\begin{array}{l}\text { Southern Serra } \\
\text { do Mar }\end{array}$ & pernix & $\begin{array}{l}\text { Pedra Branca do Araraquara } \\
\left(25^{\circ} 56^{\prime} 00^{\prime} \mathrm{S}, 48^{\circ} 52^{\prime} 50^{\prime} \mathrm{W}\right) \text {, Serra do } \\
\text { Araraquara, municipality of } \\
\text { Guaratuba }\end{array}$ & PR & 1,000 & *, DZUP \\
\hline
\end{tabular}




\begin{tabular}{|c|c|c|c|c|c|c|}
\hline Species $^{1}$ & Relief units ${ }^{2}$ & Group $^{3}$ & Locality $^{4}$ & State & Altitude & Source 5 \\
\hline $\begin{array}{l}\text { Brachycephalus sp. } \\
5\end{array}$ & $\begin{array}{l}\text { Southern Serra } \\
\text { do Mar }\end{array}$ & pernix & $\begin{array}{l}\text { Serra Canasvieiras }\left(25^{\circ} 36^{\prime} 58^{\prime} \mathrm{S} \text {, }\right. \\
\left.48^{\circ} 46^{\prime} 59^{\prime \prime} \mathrm{W}\right) \text {, boundary of the } \\
\text { municipalities of Guaratuba and } \\
\text { Morretes }\end{array}$ & PR & 1,080 & $\begin{array}{l}\text { *, DZUP, Firkowski (2013; } \\
\text { without species identification) }\end{array}$ \\
\hline $\begin{array}{l}\text { Brachycephalus sp. } \\
6\end{array}$ & $\begin{array}{l}\text { Southern Serra } \\
\text { do Mar }\end{array}$ & pernix & $\begin{array}{l}\text { Serra do Salto }\left(25^{\circ} 42^{\prime} 07^{\prime} \text { S, }\right. \\
\left.49^{\circ} 03^{\prime} 44^{\prime} \mathrm{W}\right) \text {, Malhada District, } \\
\text { municipality of São José dos Pinhais }\end{array}$ & PR & $\begin{array}{c}1,095- \\
1,160\end{array}$ & $\begin{array}{l}\text { *, DZUP, Firkowski (2013; } \\
\text { without species identification), } \\
\text { Pie et al. (2013; as } \\
\text { “Brachycephalus sp. 2") }\end{array}$ \\
\hline \multicolumn{7}{|l|}{ Excluded records ${ }^{6}$} \\
\hline B. hermogenesi & $\begin{array}{l}\text { Central Serra } \\
\text { do Mar }\end{array}$ & didactylus & Ubatuba & SP & $?$ & $\begin{array}{l}\text { Silva et al. (2007), Campos et al. } \\
\text { (2010), Campos (2011) }\end{array}$ \\
\hline B. hermogenesi & Paranapiacaba & didactylus & Municipality of Piedade & SP & $?$ & $\begin{array}{l}\text { Condez et al. (2009), Clemente- } \\
\text { Carvalho et al. (2011a) }\end{array}$ \\
\hline B. alipioi & $\begin{array}{l}\text { Northern Serra } \\
\text { da Mantiqueira }\end{array}$ & ephippium & Santa Teresa & ES & $?$ & $\begin{array}{l}\text { Pombal \& Gasparini (2006), } \\
\text { Pombal \& Izecksohn (2011) }\end{array}$ \\
\hline B. cf. crispus & $\begin{array}{l}\text { Central Serra } \\
\text { do Mar }\end{array}$ & ephippium & Cunha & SP & $?$ & $\begin{array}{l}\text { Campos et al. (2010; as } \\
\text { "Brachycephalus sp. 3"), Campos } \\
\text { (2011; as "BCU SP2") }\end{array}$ \\
\hline
\end{tabular}




\begin{tabular}{|c|c|c|c|c|c|c|}
\hline Species $^{1}$ & Relief units ${ }^{2}$ & Group $^{3}$ & Locality $^{4}$ & State & Altitude & Source 5 \\
\hline B. ephippium & $\begin{array}{l}\text { Southern Serra } \\
\text { da Mantiqueira }\end{array}$ & ephippium & Atibaia & SP & $?$ & $\begin{array}{l}\text { Pires et al. (2003, 2005), Ananias } \\
\text { et al. (2006), Clemente-Carvalho } \\
\text { et al. (2008, 2009, 2011a,b, } \\
\text { 2016), Campos et al. (2010), } \\
\text { Campos (2011; as "BAT SP3"), } \\
\text { Pombal \& Izecksohn (2011) }\end{array}$ \\
\hline B. ephippium & $\begin{array}{l}\text { Southern Serra } \\
\text { da Mantiqueira }\end{array}$ & ephippium & Itamonte & MG & $?$ & $\begin{array}{l}\text { Silva et al. (2007), Campos et al. } \\
\text { (2010), Campos (2011; as "BIT } \\
\text { MG1") }\end{array}$ \\
\hline B. ephippium & $\begin{array}{l}\text { Southern Serra } \\
\text { da Mantiqueira }\end{array}$ & ephippium & Itatiaia & RJ & $?$ & Pombal \& Izecksohn (2011) \\
\hline B. ephippium & $\begin{array}{l}\text { Southern Serra } \\
\text { da Mantiqueira }\end{array}$ & ephippium & Joaquim Egídio & SP & $?$ & Clemente-Carvalho et al. (2016) \\
\hline B. ephippium & $\begin{array}{l}\text { Southern Serra } \\
\text { da Mantiqueira }\end{array}$ & ephippium & Jundiaí & SP & $?$ & $\begin{array}{l}\text { Miranda-Ribeiro (1920), } \\
\text { Clemente-Carvalho et al. (2008, } \\
\text { 2011b) }\end{array}$ \\
\hline B. ephippium & $\begin{array}{l}\text { Southern Serra } \\
\text { da Mantiqueira }\end{array}$ & ephippium & Piquete & SP & $?$ & $\begin{array}{l}\text { Miranda-Ribeiro (1920), Pombal } \\
\text { \& Izecksohn (2011) }\end{array}$ \\
\hline B. ephippium & $\begin{array}{l}\text { Northern Serra } \\
\text { do Mar }\end{array}$ & ephippium & Angra dos Reis & $\mathrm{RJ}$ & $?$ & Pombal \& Izecksohn (2011) \\
\hline B. ephippium & $\begin{array}{l}\text { Northern Serra } \\
\text { do Mar }\end{array}$ & ephippium & $\begin{array}{l}\text { Floresta da Tijuca, municipality of } \\
\text { Rio de Janeiro }\end{array}$ & RJ & $?$ & Pombal \& Izecksohn (2011) \\
\hline
\end{tabular}




\begin{tabular}{|c|c|c|c|c|c|c|}
\hline Species $^{1}$ & Relief units ${ }^{2}$ & Group $^{3}$ & Locality $^{4}$ & State & Altitude & Source 5 \\
\hline B. ephippium & $\begin{array}{l}\text { Northern Serra } \\
\text { do Mar }\end{array}$ & ephippium & $\begin{array}{l}\text { Guapiaçu }\left(22^{\circ} 26^{\prime} 34^{\prime \prime} \mathrm{S}, 42^{\circ} 45^{\prime} 38^{\prime \prime} \mathrm{W}\right) \text {, } \\
\text { municipality of Cachoeira de Macacu }\end{array}$ & $\mathrm{RJ}$ & 35 & Pombal \& Izecksohn (2011) \\
\hline B. ephippium & $\begin{array}{l}\text { Northern Serra } \\
\text { do Mar }\end{array}$ & ephippium & Mangaratiba & $\mathrm{RJ}$ & $?$ & $\begin{array}{l}\text { Campos (2011; as “BMA RJ1”), } \\
\text { Pombal \& Izecksohn (2011) }\end{array}$ \\
\hline B. ephippium & $\begin{array}{l}\text { Northern Serra } \\
\text { do Mar }\end{array}$ & ephippium & Parque Nacional da Serra dos Órgãos & $\mathrm{RJ}$ & $?$ & Pombal \& Izecksohn (2011) \\
\hline B. ephippium & $\begin{array}{l}\text { Northern Serra } \\
\text { do Mar }\end{array}$ & ephippium & Rio de Janeiro & $\mathrm{RJ}$ & $?$ & Pombal \& Izecksohn (2011) \\
\hline B. ephippium & $\begin{array}{l}\text { Northern Serra } \\
\text { do Mar }\end{array}$ & ephippium & Teresópolis & $\mathrm{RJ}$ & $?$ & $\begin{array}{l}\text { Pires et al. (2002, 2005), Silva et } \\
\text { al. (2007), Campos et al. (2010), } \\
\text { Campos (2011; as “BTE RJ4”), } \\
\text { Pombal \& Izecksohn (2011) }\end{array}$ \\
\hline B. ephippium & $\begin{array}{l}\text { Central Serra } \\
\text { do Mar }\end{array}$ & ephippium & Bocaina & SP & $?$ & Pombal \& Izecksohn (2011) \\
\hline B. ephippium & $\begin{array}{l}\text { Central Serra } \\
\text { do Mar }\end{array}$ & ephippium & Cotia & SP & $?$ & $\begin{array}{l}\text { Silva et al. (2007), Campos et al. } \\
\text { (2010), Campos (2011; as "BCO } \\
\text { SP5") }\end{array}$ \\
\hline B. ephippium & $\begin{array}{l}\text { Central Serra } \\
\text { do Mar }\end{array}$ & ephippium & Fazenda Papagaio, Serra da Bocaina & SP & $?$ & Pombal \& Izecksohn (2011) \\
\hline
\end{tabular}




\begin{tabular}{|c|c|c|c|c|c|c|}
\hline Species $^{1}$ & Relief units ${ }^{2}$ & Group $^{3}$ & Locality $^{4}$ & State & Altitude & Source 5 \\
\hline B. ephippium & $\begin{array}{l}\text { Central Serra } \\
\text { do Mar }\end{array}$ & ephippium & Mogi das Cruzes & SP & $?$ & $\begin{array}{l}\text { Pires et al. (2005), Silva et al. } \\
\text { (2007), Campos et al. (2010), } \\
\text { Campos (2011; as "BMC SP4"), } \\
\text { Pombal \& Izecksohn (2011) }\end{array}$ \\
\hline B. ephippium & $\begin{array}{l}\text { Central Serra } \\
\text { do Mar }\end{array}$ & ephippium & Serra da Bocaina & $\mathrm{SP} / \mathrm{RJ}$ & $?$ & Pombal \& Izecksohn (2011) \\
\hline B. garbeanus & $\begin{array}{l}\text { Northern Serra } \\
\text { do Mar }\end{array}$ & ephippium & Nova Friburgo & RJ & $?$ & $\begin{array}{l}\text { Silva et al. (2007; as “B. } \\
\text { ephippium"), Campos et al. } \\
\text { (2010; as "B. ephippium”), } \\
\text { Campos (2011) }\end{array}$ \\
\hline B. margaritatus & $\begin{array}{l}\text { Northern Serra } \\
\text { do Mar }\end{array}$ & ephippium & $\begin{array}{l}\text { Sítio do Pau Ferro, Morro Azul, } \\
\text { municipality of Engenheiro Paulo de } \\
\text { Frontin }\end{array}$ & RJ & $?$ & Pombal \& Izecksohn (2011) \\
\hline B. cf. margaritatus & $\begin{array}{l}\text { Northern Serra } \\
\text { do Mar }\end{array}$ & ephippium & Petrópolis & $\mathrm{RJ}$ & $?$ & Campos (2011; as “BPT RJ3”) \\
\hline B. nodoterga & $\begin{array}{l}\text { Central Serra } \\
\text { do Mar }\end{array}$ & ephippium & Salesópolis & SP & $?$ & Pires et al. (2005) \\
\hline B. nodoterga & $\begin{array}{l}\text { Central Serra } \\
\text { do Mar }\end{array}$ & ephippium & Santana de Parnaíba & SP & $?$ & Abegg et al. (2015) \\
\hline
\end{tabular}




\begin{tabular}{|c|c|c|c|c|c|c|}
\hline Species $^{1}$ & Relief units ${ }^{2}$ & Group $^{3}$ & Locality $^{4}$ & State & Altitude & Source $^{5}$ \\
\hline B. toby & $\begin{array}{l}\text { Central Serra } \\
\text { do Mar }\end{array}$ & ephippium & Ubatuba & SP & $?$ & $\begin{array}{l}\text { Silva et al. (2007; as } \\
\text { "Brachycephalus cf. } \\
\text { vertebralis"), Campos et al. } \\
\text { (2010; as "Brachycephalus cf. } \\
\text { vertebralis"), Campos (2011) }\end{array}$ \\
\hline B. vertebralis & $\begin{array}{l}\text { Central Serra } \\
\text { do Mar }\end{array}$ & ephippium & Cunha & SP & $?$ & Pombal (2001) \\
\hline B. vertebralis & $\begin{array}{l}\text { Central Serra } \\
\text { do Mar }\end{array}$ & ephippium & Parati & $\mathrm{RJ}$ & $?$ & $\begin{array}{l}\text { Silva et al. (2007), Campos et al. } \\
\text { (2010), Campos (2011) }\end{array}$ \\
\hline $\begin{array}{l}\text { Brachycephalus sp. } \\
7\end{array}$ & $\begin{array}{l}\text { Central Serra } \\
\text { do Mar }\end{array}$ & ephippium & Biritiba-Mirim & SP & $?$ & $\begin{array}{l}\text { Silva et al. (2007; as "B. } \\
\text { nodoterga"), Campos et al. (2010; } \\
\text { as "Brachycephalus sp. 1"), } \\
\text { Campos (2011; as "BBM SP1") }\end{array}$ \\
\hline B. brunneus & $\begin{array}{l}\text { Southern Serra } \\
\text { do Mar }\end{array}$ & pernix & Campina Grande do Sul & PR & $?$ & $\begin{array}{l}\text { Silva et al. (2007), Campos et al. } \\
\text { (2010), Campos (2011) }\end{array}$ \\
\hline $\begin{array}{l}\text { Brachycephalus } \\
\text { leopardus }\end{array}$ & $\begin{array}{l}\text { Southern Serra } \\
\text { do Mar }\end{array}$ & pernix & Tijucas do Sul & PR & $?$ & Campos (2011; as “BTS PR”) \\
\hline B. atelopoide & $\begin{array}{l}\text { Southern Serra } \\
\text { da Mantiqueira }\end{array}$ & $?$ & Piquete & SP & $?$ & Miranda-Ribeiro (1920) \\
\hline $\begin{array}{l}\text { Brachycephalus sp. } \\
\text { cf. Brachycephalus } \\
\text { sp. } 1\end{array}$ & Paranapiacaba & didactylus & Municipality of Ribeirão Grande & SP & $?$ & $\begin{array}{l}\text { Verdade et al. (2008; as “ } B \text {. } \\
\text { hermogenesi”) }\end{array}$ \\
\hline
\end{tabular}




\begin{tabular}{|c|c|c|c|c|c|c|}
\hline Species $^{1}$ & Relief units ${ }^{2}$ & Group $^{3}$ & Locality $^{4}$ & State & Altitude & Source 5 \\
\hline $\begin{array}{l}\text { Brachycephalus sp. } \\
\text { cf. Brachycephalus } \\
\text { sp. } 1\end{array}$ & Paranapiacaba & didactylus & Municipality of Tapiraí & SP & $?$ & $\begin{array}{l}\text { Verdade et al. (2008; as “B. } \\
\text { hermogenesi”), Condez et al. } \\
\text { (2009; as “B. hermogenesi”) }\end{array}$ \\
\hline $\begin{array}{l}\text { Brachycephalus sp. } \\
\text { cf. Brachycephalus } \\
\text { sp. } 1\end{array}$ & Paranapiacaba & didactylus & Municipality of Juquitiba & SP & $?$ & $\begin{array}{l}\text { Verdade et al. (2008; as “ } B \text {. } \\
\text { hermogenesi”) }\end{array}$ \\
\hline $\begin{array}{l}\text { Brachycephalus sp. } \\
\text { cf. Brachycephalus } \\
\text { sp. } 1\end{array}$ & $\begin{array}{l}\text { Central Serra } \\
\text { do Mar }\end{array}$ & didactylus & $\begin{array}{l}\text { Estação Ecológica Juréia-Itatins, } \\
\text { municipality of Iguape }\end{array}$ & SP & $?$ & $\begin{array}{l}\text { Verdade et al. (2008; as “ } B \text {. } \\
\text { hermogenesi”) }\end{array}$ \\
\hline $\begin{array}{l}\text { Brachycephalus sp. } \\
\text { cf. Brachycephalus } \\
\text { sp. } 1\end{array}$ & $\begin{array}{l}\text { Southern Serra } \\
\text { do Mar }\end{array}$ & didactylus & $\begin{array}{l}\text { Ilha do Cardoso, municipality of } \\
\text { Cananéia }\end{array}$ & SP & $?$ & $\begin{array}{l}\text { Verdade et al. (2008; as "possibly } \\
\text { B. hermogenesi") }\end{array}$ \\
\hline
\end{tabular}

${ }^{1}$ Species and records are ordered by the following criteria: alphabetic order of groups and alphabetic order of species by groups.

8392 According to IBAMA (2007), with additional subdivisions (see Materials and methods).

$840{ }^{3}$ For group definitions, see Materials and methods.

$841{ }^{4}$ Geographical coordinates are based on the datum WGS84.

$842{ }^{5}$ DZUP $=$ Coleção de Herpetologia, Departamento de Zoologia, Universidade Federal do Paraná, state of Paraná, Brazil; MHNCI =

843 Museu de História Natural Capão da Imbuia, Prefeitura Municipal de Curitiba, state of Paraná, Brazil.

$844{ }^{6}$ Excluded records represent vague localities, general reference of municipality of locality, and localities that were specified but could

845 not be located or were questionable given exceedingly low associated altitude.

$846 *=$ This study (unpublished data). 
848 Table 2. Number of species of Brachycephalus per relief unit.

\begin{tabular}{lcc}
\hline Relief unit $^{1}$ & $\begin{array}{c}\text { Number of } \\
\text { groups }\end{array}$ & $\begin{array}{c}\text { Number of species (undescribed } \\
\text { species included) }\end{array}$ \\
\hline Pré-Litorâneas & 1 & $1(0)$ \\
Serra da Mantiqueira & 2 & $3(0)$ \\
$\quad$ Northern Serra da Mantiqueira & 2 & $3(0)$ \\
$\quad$ Southern Serra da Mantiqueira & 1 & $1(0)$ \\
Paraíba do Sul & 1 & $1(0)$ \\
Serra do Mar & 3 & $30(6)$ \\
$\quad$ Northern Serra do Mar & 2 & $6(1)$ \\
Central Serra do Mar & 2 & $9(1)$ \\
$\quad$ Southern Serra do Mar & 2 & $16(4)$ \\
Paranapiacaba & 1 & $1(1)$ \\
Leste Catarinense & 1 & $3(0)$
\end{tabular}

$849{ }^{1}$ According to IBAMA (2007), with additional subdivisions in the units Serra da Mantiqueira 850 and Serra do Mar (see Materials and methods). 
852 Table 3. Number of species of Brachycephalus per group in each relief unit.

\begin{tabular}{lccc}
\hline & \multicolumn{2}{c}{ Number of species per group (undescribed species } \\
Relief unit & & included) \\
& & ephippium & pernix \\
\cline { 2 - 3 } & didactylus & 0 & 0 \\
\hline Pré-Litorâneas & $1(0)$ & $2(0)$ & 0 \\
Serra da Mantiqueira & $1(0)$ & $2(0)$ & 0 \\
$\quad$ Northern Serra da Mantiqueira & $1(0)$ & $1(0)$ & 0 \\
Southern Serra da Mantiqueira & 0 & $1(0)$ & 0 \\
Paraíba do Sul & 0 & $12(2)$ & 0 \\
Serra do Mar & $3(1)$ & $5(1)$ & 0 \\
Northern Serra do Mar & $1(0)$ & $8(1)$ & $15(3)$ \\
Central Serra do Mar & $1(0)$ & 0 & 0 \\
Southern Serra do Mar & $1(1)$ & 0 & $3(0)$ \\
Paranapiacaba & $1(1)$ & 0 & 0
\end{tabular}

$853{ }^{1}$ According to IBAMA (2007), with additional subdivisions in the units Serra da Mantiqueira 854 and Serra do Mar (see Materials and methods). 
856 Table 4. Altitudinal distribution and "extent of occurrence" (sensu IUCN 2012) of

857 Brachycephalus spp. Only confirmed altitudinal records are considered. Extent of occurrence by 858 altitude (Alt) or by an adaptation of the minimum convex polygon (MCP; see text for details).

\begin{tabular}{|c|c|c|c|c|}
\hline \multirow{2}{*}{ Species $^{1}$} & \multicolumn{2}{|c|}{ Altitudinal distribution ( $\mathrm{m}$ a.s.1.) } & \multicolumn{2}{|c|}{ Extent of occurrence (ha) } \\
\hline & Range & Amplitude & Alt & MCP \\
\hline didactylus group & $0-1,110$ & 1,110 & - & - \\
\hline B. didactylus (dida) & $35-1,110$ & 1,075 & $?$ & $?$ \\
\hline B. hermogenesi (herm) & $0-900$ & 900 & - & $567,589.87$ \\
\hline B. pulex & $800-930$ & 130 & 488.25 & - \\
\hline Brachycephalus sp. 1 (sp.1) & $25-1,060$ & 1,035 & - & $778,458.42$ \\
\hline ephippium group & $200-1,900$ & 1,700 & - & - \\
\hline B. alipioi & $1,070-1,100$ & 30 & $?$ & $?$ \\
\hline B. crispus (cris) & $800-1,100$ & 300 & $?$ & $?$ \\
\hline B. ephippium (ephi) & $200-1,250$ & 1,050 & $?$ & $?$ \\
\hline B. garbeanus (garb) & $1,130-1,900$ & 770 & - & $12,268.00$ \\
\hline B. guarani (guar) & $500-900$ & 400 & $?$ & $?$ \\
\hline B. margaritatus (marg) & $600-980$ & 380 & - & $18,272.87$ \\
\hline B. nodoterga (nodo) & $700-945$ & 245 & $?$ & $?$ \\
\hline B. pitanga (pita) & $900-1,140$ & 240 & - & $2,377.07$ \\
\hline B. toby (toby) & 750 & 0 & $?$ & $?$ \\
\hline B. vertebralis (vert) & 900 & 0 & $?$ & $?$ \\
\hline Brachycephalus sp. 2 (sp.2) & $1,100-1,200$ & 100 & $?$ & $?$ \\
\hline Brachycephalus sp. 3 (sp.3) & $800-825$ & 25 & $?$ & $?$ \\
\hline pernix group & $455-1,640$ & 1,185 & - & - \\
\hline B. auroguttatus (auro) & $1,070-1,100$ & 30 & $?$ & $?$ \\
\hline B. boticario & $755-795$ & 40 & 11.07 & - \\
\hline B. brunneus (brun) & $1,095-1,630$ & 535 & $5,687.08$ & - \\
\hline B. ferruginus (ferr) & $965-1,470$ & 505 & $5,475.51$ & - \\
\hline B. fuscolineatus & $640-790$ & 150 & 23.63 & - \\
\hline B. izecksohni (izec) & $980-1,340$ & 360 & 350.43 & - \\
\hline B. leopardus (leop) & $1,400-1,640$ & 240 & 176.73 & - \\
\hline
\end{tabular}




\begin{tabular}{|c|c|c|c|c|}
\hline \multirow{2}{*}{ Species $^{1}$} & \multicolumn{2}{|c|}{ Altitudinal distribution (m a.s.l.) } & \multicolumn{2}{|c|}{ Extent of occurrence (ha) } \\
\hline & Range & Amplitude & Alt & $\mathrm{MCP}$ \\
\hline B. mariaeterezae (mari) & $1,265-1,270$ & 5 & $?$ & $?$ \\
\hline B. olivaceus (oliv) & $690-985$ & 295 & - & $12,531.64$ \\
\hline B. pernix (pern) & $1,135-1,405$ & 270 & 432.10 & - \\
\hline B. pombali (pomb) & $845-1,300$ & 455 & $?$ & $?$ \\
\hline B. quiririensis (quir) & $1,240-1,380$ & 140 & $1,338.97$ & - \\
\hline B. tridactylus (trid) & $805-910$ & 105 & 41.42 & - \\
\hline B. verrucosus (verr) & $455-945$ & 490 & $?$ & $?$ \\
\hline Brachycephalus sp. 4 (sp.4) & $1,250-1,320$ & 70 & $?$ & $?$ \\
\hline Brachycephalus sp. 5 (sp.5) & $1,000-1,080$ & 80 & $?$ & $?$ \\
\hline Brachycephalus sp. 6 (sp.6) & $1,095-1,160$ & 65 & $2,211.54$ & - \\
\hline
\end{tabular}

859

${ }^{1}$ Abreviation in parentheses refers to species acronyms in Fig. 1.

860

861 


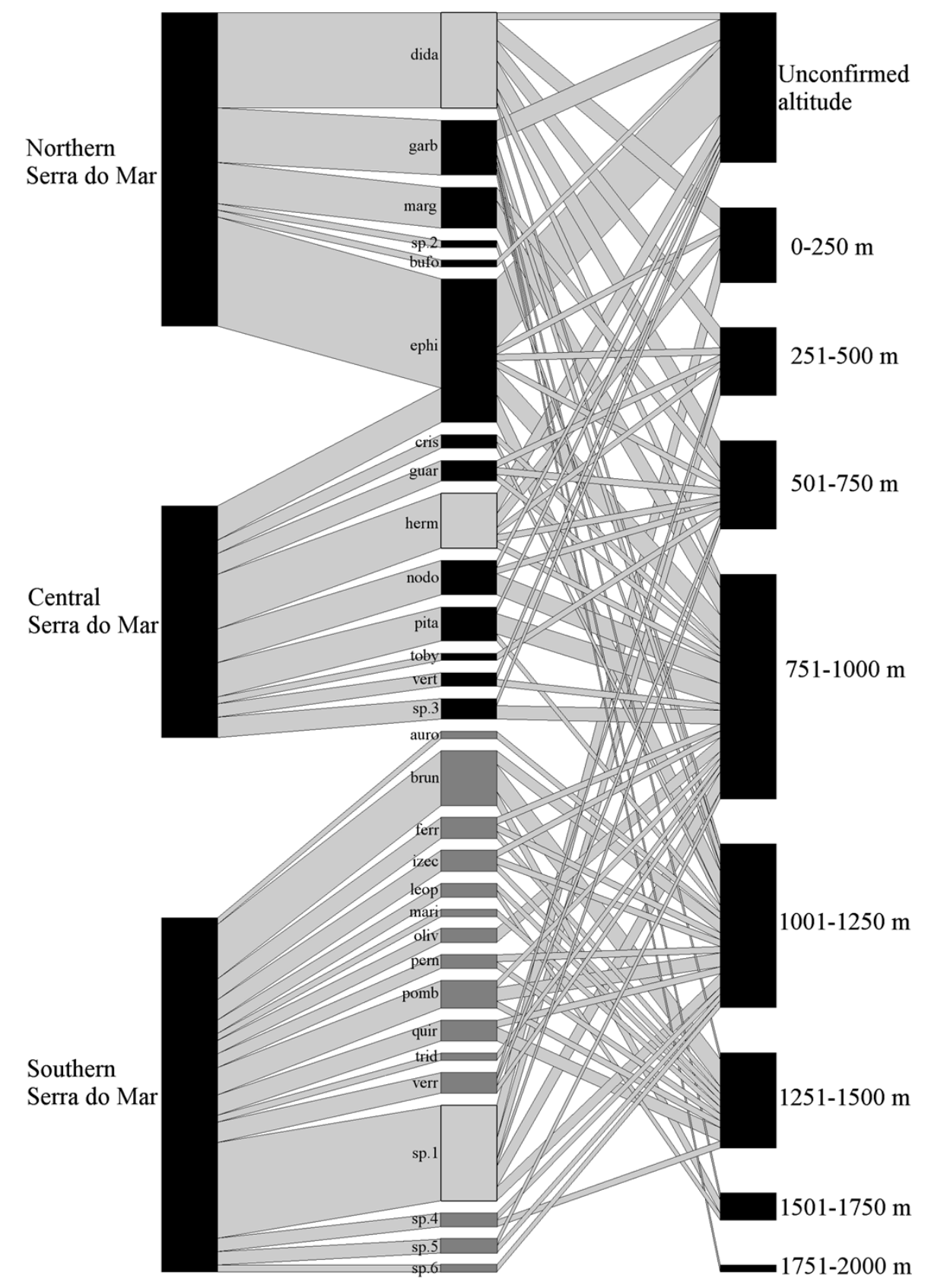

863 Figure 1. Geographical and altitudinal distribution of Brachycephalus spp. according to their respective species group (light gray $=$ didactylus, black $=$ ephippium, and dark gray $=$ pernix

865 group) across the three sectors of the Serra do Mar relief unit. The species connections represent 866 the occurrence in each sector of the relief unit (left boxes) and in altitudinal quotas (left boxes).

867 The width of the connections (in both directions) represents the proportional amount of citations 
868 in the bibliography for each sector and altitude quotas (wider = more citations). See Tab. 4 for 869 the correspondence of the acronyms with the species name.

870 
871
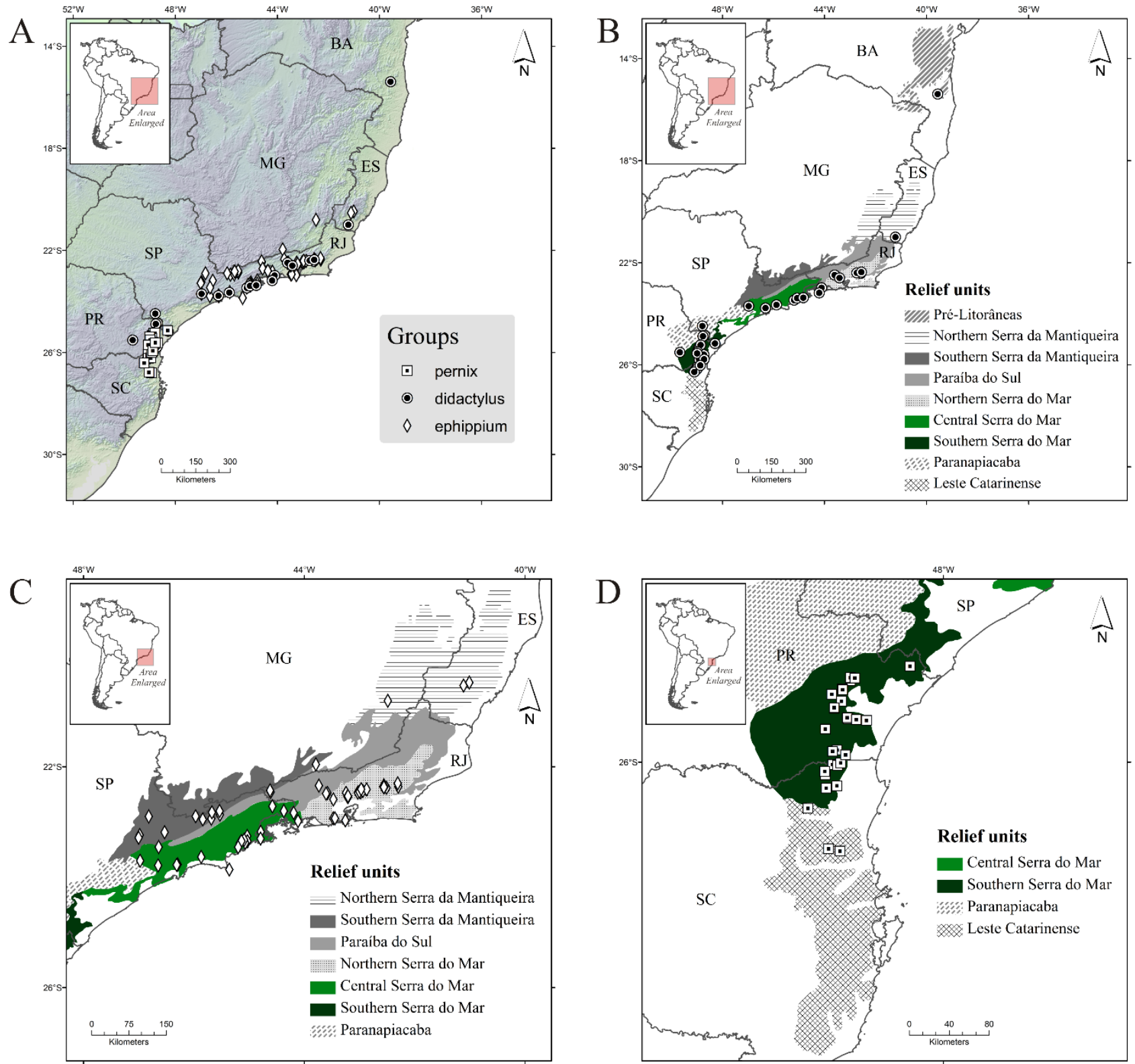

872

873 Figure 2. Occurrence records of Brachycephalus spp. $\mathrm{A}=$ all species; $\mathrm{B}=$ species of the

874 didactylus group; $\mathrm{C}=$ species of the ephippium group; $\mathrm{D}=$ species of the pernix group.

875 Diamonds = records of the ephippium group; circles = records of the didactylus group; and squares $=$ records of the pernix group. Abbreviations: $\mathrm{BA}=$ Bahia; $\mathrm{MG}=$ Minas Gerais; $\mathrm{ES}=$

877 Espírito Santo; RJ = Rio de Janeiro; SP = São Paulo; PR = Paraná; and SC = Santa Catarina.

878 Relief units modified from IBAMA (2007). 
880
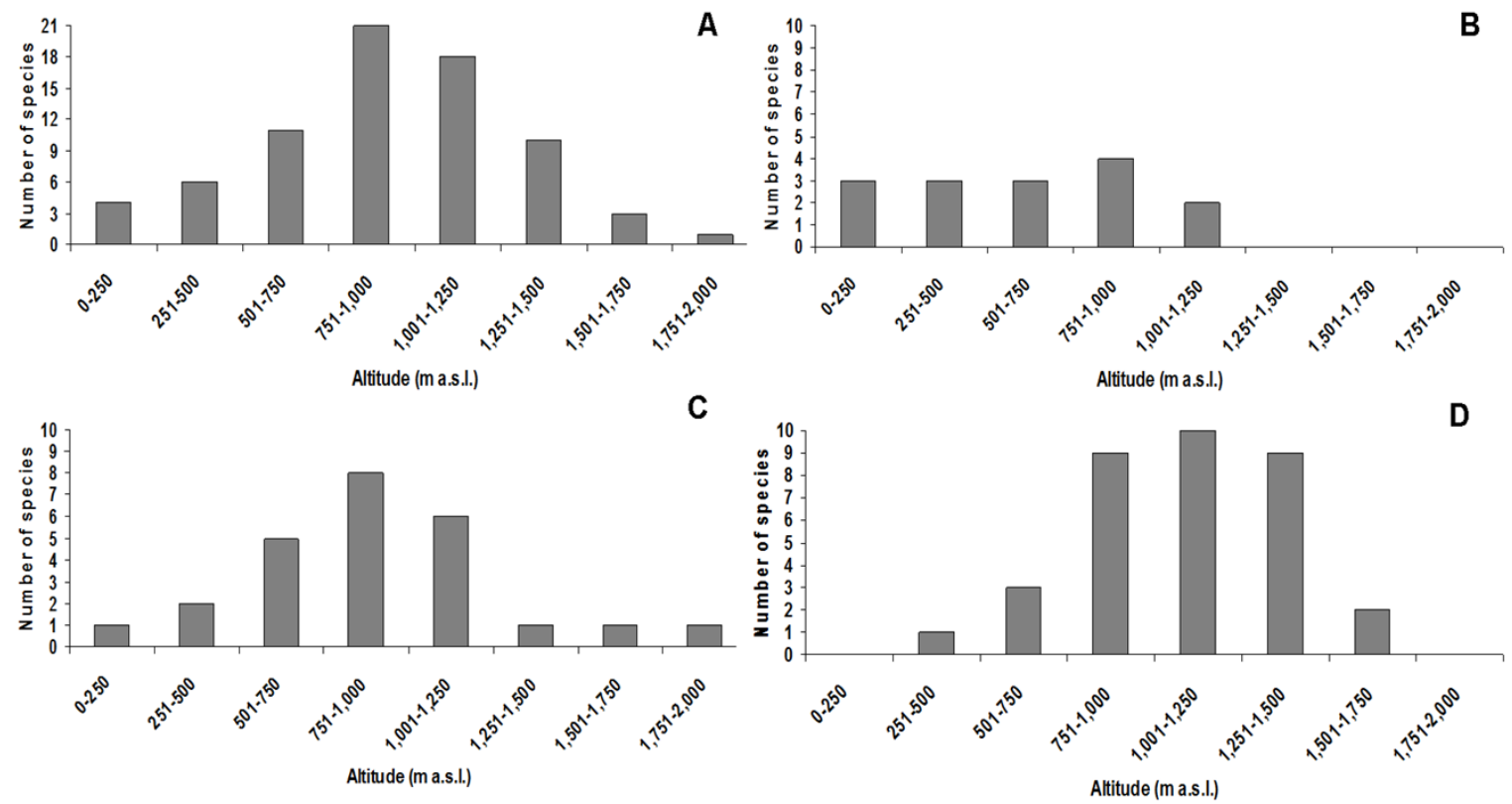

881

882 Figure 3. Species richness of Brachycephalus in each altitudinal class (including undescribed

883 species). $\mathrm{A}=$ all species; $\mathrm{B}=$ species of the didactylus group; $\mathrm{C}=$ species of the ephippium

884 group; $\mathrm{D}=$ species of the pernix group.

885 
886

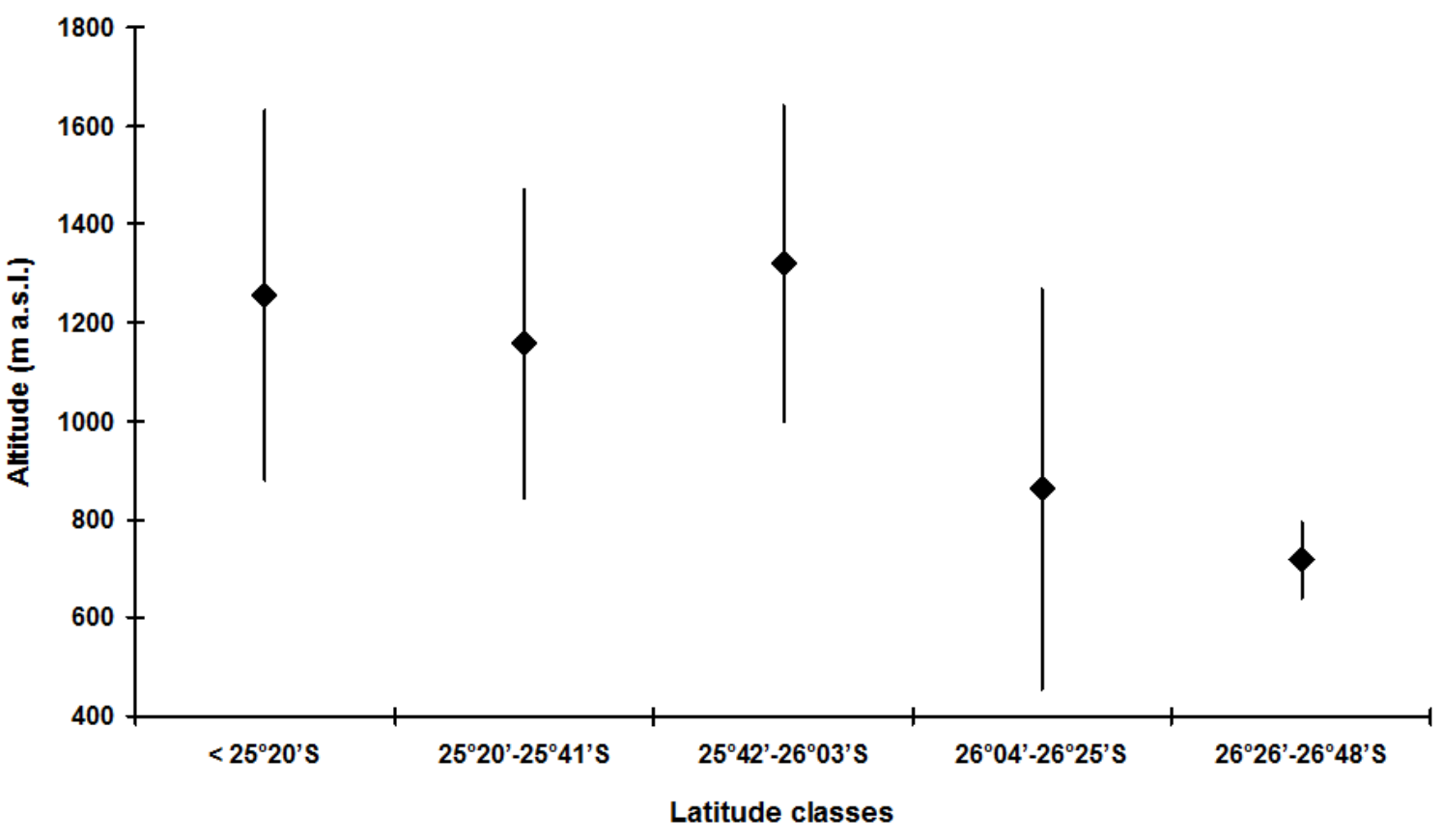

887

888 Figure 4. Altitudinal amplitude records of Brachycephalus spp. from the pernix group binned 889 into latitudinal classes (including undescribed species). Diamonds indicate median values. 